University of Rhode Island

DigitalCommons@URI

Open Access Master's Theses

1986

\title{
LAND-USE CONTROL CASE ANALYSIS SPECIAL AREA \\ MANAGEMENT PLAN
}

Thomas J. Quinn

University of Rhode Island

Follow this and additional works at: https://digitalcommons.uri.edu/theses

\section{Recommended Citation}

Quinn, Thomas J., "LAND-USE CONTROL CASE ANALYSIS SPECIAL AREA MANAGEMENT PLAN" (1986). Open Access Master's Theses. Paper 391.

https://digitalcommons.uri.edu/theses/391

This Thesis is brought to you for free and open access by DigitalCommons@URI. It has been accepted for inclusion in Open Access Master's Theses by an authorized administrator of DigitalCommons@URI. For more information, please contact digitalcommons-group@uri.edu. 


\author{
LAND-USE CONTROL \\ CASE ANALYSIS \\ SPECIAL AREA MANAGEMENT PLAN \\ BY \\ THOMAS J. QUINN \\ A RESEARCH PROJECT SUBMITTED IN \\ PARTIAL FULFILLMENT OF THE-REQOIREMENTS \\ FOR THE DEGREE AND MASTER OF \\ COMMUNITY PLANNING \\ UNIVERSITY OF RHODE ISLAND \\ 1986
}




\section{MASTER OF COMMUNITY PLANNING}

\section{RESEARCH PROJECT}

OF

THOMAS J Q QUINN

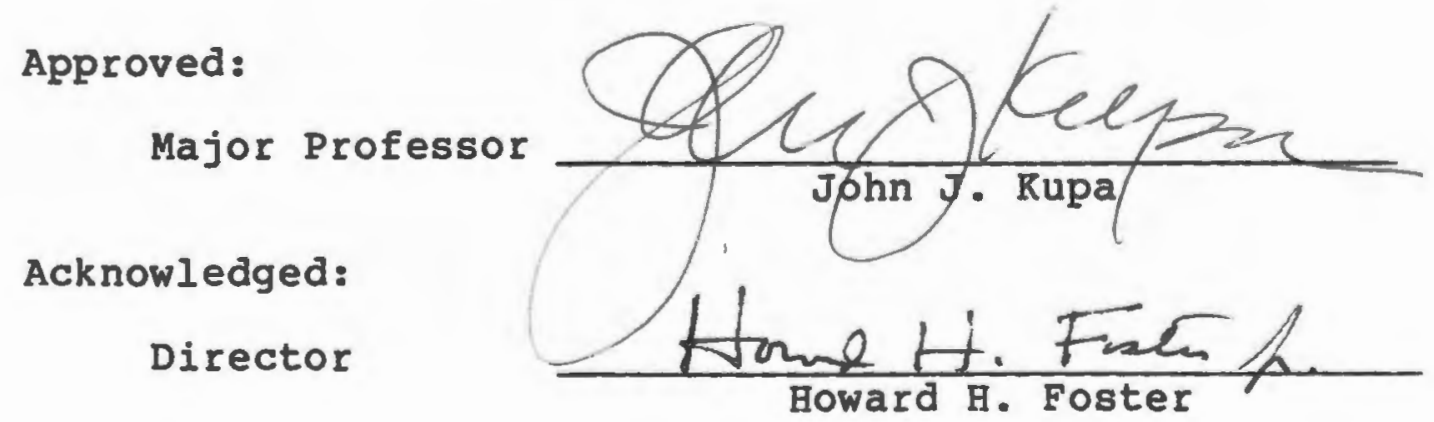




\section{ABSTRACT}

This research project is a case study of land-use decision making in Rhode Island. Choices concerning land development effect people within the local and citizenry throughout the state. Land use evolution and its controls have been incremental with various catalysts serving as the shaper and influencer. Historically, land-use planning and decision-making is found at the local level. The perception of individual property rights and land-use controls at the local level are related. Environmental considerations are steeped in inherent societal rights.

Rights to private property is a constitutional hallmark. Environmental protection is a legislative mandate. Perceptions of these rights contribute to a planning dilemma: individual rights versus societal rights. Awareness of this fact is one of the underpinnings of citizen participation.

Historically comprehensive planning has been developed on a local level (701 program) by officials, directly or indirectly, responsible to a specific constituency. Obstensibly these plans reflect the will of the people through the electoral process and via citizen participation during plan formulation. The mechanisms and apparatus for environmental protection is appropriately found at the state level. Pertinent 
questions in the discussions are what authority is making the decision and how is land-use decision-making influenced vis-a-vis state policy making? Until this issue is resolved the conflict and confusion of incrementalism will reign over any true attempts at comprehensive planning. An attempt to verify this view uses the Rhode Island Coastal Zone Management Act 1971 (RICZMA) •

The RICZMA is the case study. This law provides the legal authority for the Salt Pond Special Area Management Plan. The plan is regional in scope and comprehensive in nature and significantly expands the heretofore borders of the coastal zone. The plan establishes dual responsibility for land-use authority. As previously mentioned this establishes significant policy questions concerning land-use decision-making and the basic format of future community growth with implications toward the formation of a comprehensive community plan. This project will document and explain the advent of and problem associated with the dual landuse decision-making process. 


\section{ACKNOWLEDGEMENTS}

I would like to thank my major professor, Dr. John Kupa, and my outside reviewer, Mr. William Sheridan Their comments, direction and encouragement helped immensely. My typist, Cynthia McLean, whose diligence is greatly appreciated. And finally my two Annes, wife and daughter, if it weren't for their motivation and beliefs I would not have accomplished my goal. 


\section{PREFACE}

The evolution of land-use controls and the perception of property rights have contributed to a disjointed incremental system of land-use planning. Modern day environmental considerations require a comprehensive approach to intensity and types of landuse. These facts produce a dilemma that should be resolved by the legislative process. Recent legislative attempts have failed to resolve the situation, creating a need for sound comprehensive planning based on a variety of factors. Many professional planners and administrators are aware of this. To fill this void, some state agencies and regulatory bodies have produced environmentally sound comprehensive plans.

Community development requires a flexible approach based on a multitude of issues. The environment is an important consideration, but not the sole factor in guiding community growth. Using the preservation of ecological systems as the primary principal for planning; the Coastal Resource Center has developed plans which limit flexibility and control in community development. The process in which these plans develop was bureaucratic and administrative rather than legislative. The history of land-use control rests with the local level government. This paper identifies problems associated with a regulatory council assuming implied powers over land-use control. 
$\underline{\text { TABLES }}$

$\underline{\text { TABLE }} \underline{4-1}$

Years and Amendments to Coastal

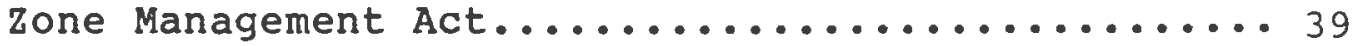

TABLE $\underline{5-1}$

List of Goals for the Special Area

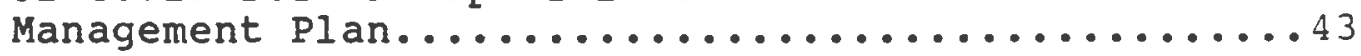

$\underline{\text { TABLE }} \underline{5-2}$

Median income levels of counties in Long Island and

Management Plan's Washington County, R.I. .......54

TABLE $6-1$

1975 State Land-Use Shore Region Policies............61

TABLE $\underline{6-2}$

Nitrate Source for a Salt Pond.................67 
TABLE OF CONTENTS

INTRODUCTION

PART I - EVOLUTION OF LAND-USE CONTROL.......

Chapter

I - PERCEPTIONS AND LAND-USE CONTROL I

Mediterranean Experience ..............

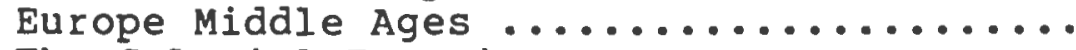

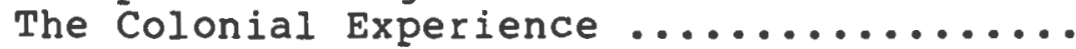

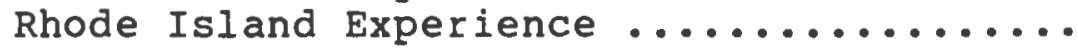
Rhode Island Land-Use .................

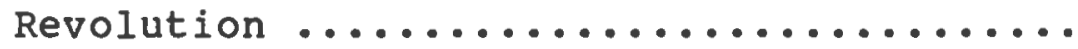

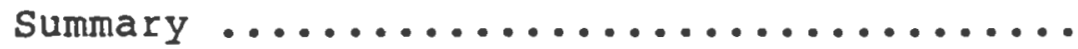

II - LAND-USE CONTROL R.I. EXPERIENCE 13

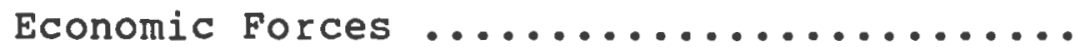

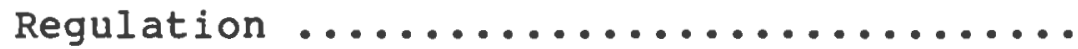

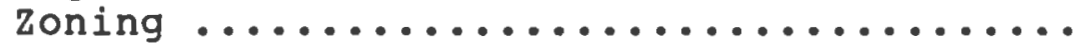

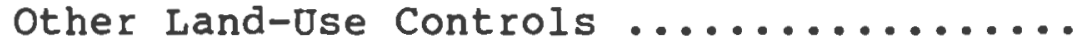
Summary ........................

III - COMPREHENSIVE PLANNING THE MISNOMER 21

History ....................... Environment

Aftermath

INTRODUCTION

PART II - CASE ANALYSIS................

Chapter

IV - RHODE ISLAND COASTAL ZONE 29

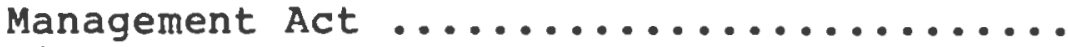

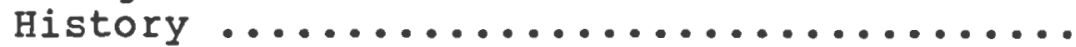
Policy Development .................. Lightering Policy ...................

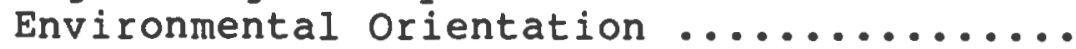

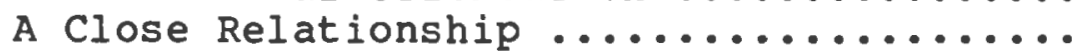

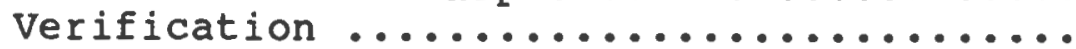

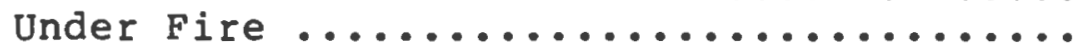

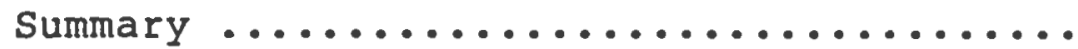


$V$ - SALT POND REGION - A SPECIAL

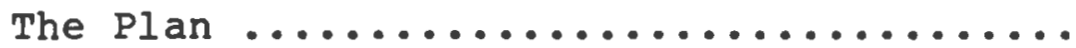

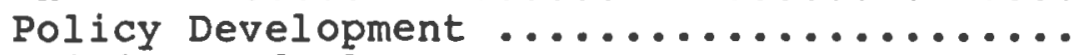

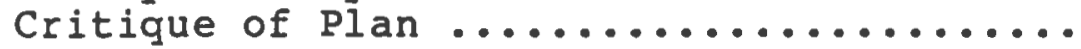

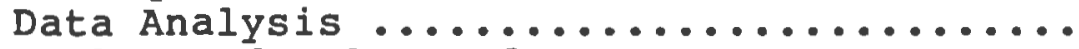
Ecology of Salt Ponds ...............

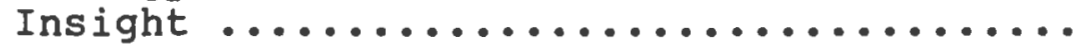

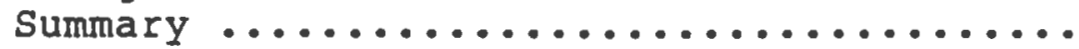

VI - LESSONS IN BUREAUCRACY

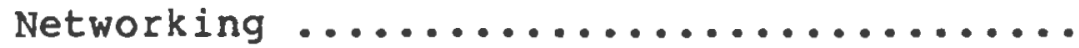

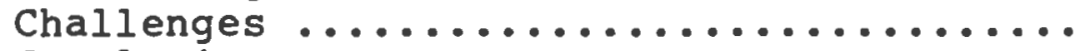

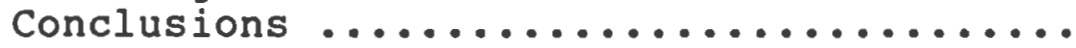
Recommendations .................. 


\section{INTRODUCTION - $\underline{\text { PART }} \underline{I}$}

The first part of this project is concerned with establishing a historical framework. Background information regarding man's perceptions of land, property rights and the evolution of the legal system controlling land-use is presented. Chapter I describes human development and the everchanging perceptions towards land. Chapter II is devoted to the nature of active and passive land-use controls. Chapter III depicts the evolving nature of comprehensive planning. The brief overviews presented, hopefully, will establish sufficient knowledge for an analysis to be presented in Part II; A case study of the Salt Pond Special Management Area. 
Chapter I is a selective overview of various culture's perception of land and its use over time. It provides a small measure in understanding the concept of ownership and its legal authority. It assumes land-use planning and decision-making are tantamount.

\section{CHAPTER I}

\section{Perceptions and Land-Use}

Human development parallels the development of land and there has always been a close relationship between both; even to the point where people are willing to die defending land.

One standard used in determining civilized man is collectivized society. To sustain early society, rudimentary agriculture replaced foraging. Since early days man has left his mark in the form of land use. Man, the environ, and land ownership and use are dynamic forces continually interacting. Ancient civilizations like Greece and Rome and the manors of feudal England all practiced land-use planning. Basic questions used to formulate their land-use are still operative today and include who, where, why and how.

\section{Mediterranean Experience}

Many thousands of years ago land-use decisions were made with large projects such as the pyramids of Egypt or the Hanging Gardens of Babylon. These required political decisions on a type of land-use. Not all 
human development was planned.

springs, river-crossings, harbors and crossroads provided some of the essentials necessary to Iive collectively. Springs provided water to drink and waterways served as a transportation network. Geologic processes made fertile grounds for crops adjacent to the land-water interface. Crossroads aided in communications between cities and regions. The natural selection of such areas helped in the inter and intrastructure needed for collectivized society. Planning was minimal and accredited growth was often the case. Modern man still migrates toward the coastal zone, utilizing planning techniques to minimize his impact.

"The Greeks credited Hippodamos with the invention invention of formal city planning."(1)

Much of Greece's physical planning was in othogonal schemes, i.e. gridded blocks based on intersections of streets at right angles. Zoning is also evident in ancient Greece. Military zones for defense, religious areas and public zones existed.

The works of Aristotle and Plato utilized principles of contemporary land-use.

"Among these we find a basic distinction between public and private property (often including a right of expropriation when in the public interest); the nomination of magistrates to supervise the public domain, including such vital services as streets, water supply and drainage; other magistrates to supervise the markets and other commercial activities, sometimes an architect to maintain public 
buildings;... and a mass of detailed provisions regulating the uses and abuses of private property".(2)

The providing of functional systems as water, drainage and streets are key elements in planning and controlling land-use. Persons charged.with directing this growth are analgolous to contemporary planners. The society's right to expropriate private property is evident. This right to eminent domain presumes society's right having precedent over property rights. The evolution of man's systematic interaction with the environment is old.

\footnotetext{
"Polis is a Greek word meaning "the selfevident expression of a way of life, an all embracing attitude to man and his environment". (3)
}

This perception of life provided parameters for planning to take place in. The word Agora described the political and social institutions within the polis. Agora "combined the functions of a market place, a place of assembly and a setting for ceremonies and spectacles the natural form of civic life for which there was no other specific provisions." (4)

The conceptual views of Greeks and their land demonstrate an order and harmony for their society. This view suggests society on the whole is greater than the individual parts. The Polis and Agora concept introduce the understanding of limitations or regulations on individual rights vis a vis societal rights.

The planning and perceptions of the Greeks are 
amazingly similar to notions within the contemporary views of comprehensive planning and land-use decision making.

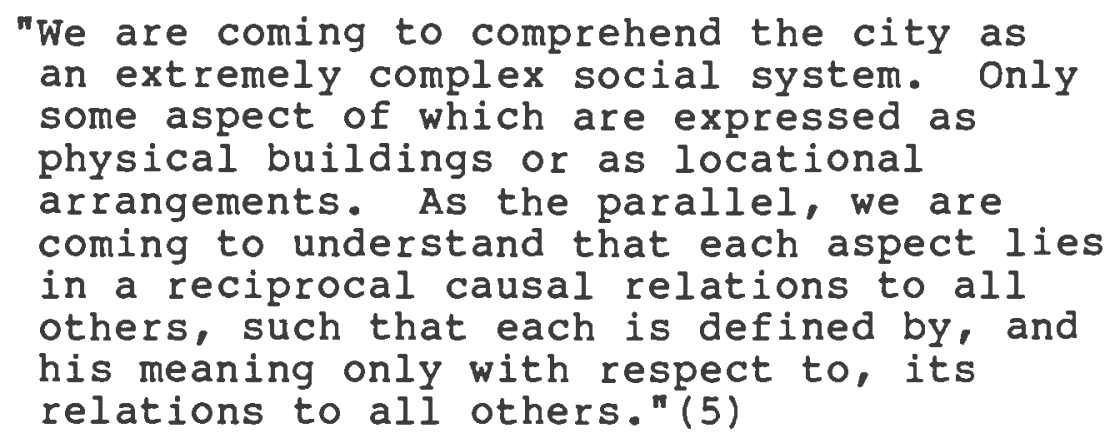

Understanding the development of laws and societies explains the current perception of man and his environment. The dynamic forces of man, environment, land ownership and use did not always maintain such a clear synergistic approach. The basic question of who, where, why and how became more narrow and less altruistic.

\section{Europe Middle-Ages}

To understand the system of land tenure and feudalism; its impact in English law (hence American law) must be examined. Feudalism evolved over two thousand years and eventually was weaned from existence. During its reign important legal and social concepts emerged. Property rights and land ownership were systematically incorporated into English law. This same English law affected the colonial perception of land. A brief overview follows.

The Celts were warlike people who invaded England around 600 B.C. They worshipped might and 
"during the following centuries emphasized the meaning that 'might makes right'; forcing the weak to seek the protection of the strong and permitting the strong to assume leadership." (6)

From this situation developed the military and political hierarchy, eventually known as the feudal system.

The social and political advances of Greek and Roman civilizations never reached England. Although England was conquered by Julius Caesar in 55 B.C., it remained little more than a distant outpost. After the fall of the Roman Empire, England was invaded by the Saxons of Geraminc origin, their culture was definite in nature.

A concept of Saxon culture was called "folcland" which means all of the land belongs to all of the people. Eventually the political evolution coined a word "bocland" meaning land granted by the book. The King began this practice of granting certain parcels of "folcland" to become "bocland" for political and military reasons.

"This practice melded with the Celtic concepts of 'might is right' and protection of the weak leading to the beginnings of a feudal system." (7)

Land tenure was a corollary to "folcland"; that is to say absolute ownership in the land remained with the sovereign. In other words, feudalism was in this regard a system of government based upon the organization of society upon the land. The underlying assumption is that property rights stem from society. This is an 
important subtlety to keep in mind. The European notion of property rights is different than the American concept of property rights. The American view is in part a reaction to the European experience.

William the I, Duke of Normandy, invaded England in 1066 and replaced the Saxons. With him he brought the Norman charter. The charter replaced the "bocland" and further codified feudalism.

The main land-use during the feudal period was a manor. In essence a manor could be thought of as a subsistent principality. It consisted of a walled fortress, usually in the form of a castle. The lord of the castle was in charge of the people (called serfs) who worked the surrounding farm land. In return for protection the serfs gave the product of their toils to the lord. Gradually these lords sought more autonomy from the Ring.

The Magna Carta in 1215 established and codified a system of redress among the $\mathrm{king}$ and the lords or landed gentry. Over the next 445 years there were many adjustments in the English feudal land tenure. The land tenure system culminated in 1660

"with the statute of Tenures, which outlawed the last important vestiges of the feudal land system." (8)

The feudal system of land tenure was still operative during the European exploration of the Americas. The feudal structure helped in the 
interaction of social, political and economic needs of the time.

\section{The Colonial Experience}

When Columbus discovered the New World competition began for new lands. European sovereigns claimed ownership chiefly by discovery and settlement. The English were the principal European power most interested in settlements in the New World. The Dutch did establish several large settlements, the most well known on the island of Manhattan in New York. In 1626, the Dutch bought New York for trade worth $\$ 24$. This practice of purchasing land from the Indians was practiced by the British as well.

$$
\begin{aligned}
& \text { "The process by which the white man acquired } \\
& \text { the land of the Indians ranged all the way } \\
& \text { from outright seizure to free barter and } \\
& \text { sale. Most of the land was purchased, } \\
& \text { although many of the Indians probably never } \\
& \text { fully understood that they were alienating } \\
& \text { their possessions forever."(9) }
\end{aligned}
$$

The Indians did not view land in terms of private property. Indians saw land as communally owned, the right to occupancy was paramount to possession.

The colonies legal authority was in the form of a charter from the king. Subsequent land grants emanated from these grants. In town areas lots were parceled out and were registered with the local government. Larger areas, known as plantations, were devoted mainly to agriculture. 


\section{The Rhode Island Experience}

Roger Williams founded Providence, Rhode Island in 1636. Religious friction forced Roger Williams out of Massachusetts Bay colony. He viewed his rights in the land as being derived from the Indians and the natural rights of man.

By 1640 the settlement at Providence wanted a formal social and political compact under which the town would be governed. The independent colonies of Portsmouth and Newport joined with Providence to form Rhode Island and Providence Plantations. The first General Assembly was held in 1647. This independent character and adherence to local autonomy remain strong today.

As a response to pressure for control by Massachusetts, Roger Williams went to England. In 1643 he obtained a charter endorsing the uniting of Providence, Newport and Portsmouth. Bhode Island's boundaries are essentially the same today.

Rhode Island Land-Use

Over the past 350 years Rhode Island's Iand-use has been closely tied to its waters. Narragansett Bay served as a transportation system for its early settlers. The location of new towns was tied to this transportation system. The fourth town, Warwick, was located on Greenwich Bay in 1693. The fifth town, Westerly, was founded in 1661 and was located on Rhode 
Island sound. This trend continued. In addition, water served as power to the early settlers. This was the only source of power for the saw mills and grist mills which dotted the state. Rhode Island's people throughout history have had close ties to the water. Explaining one of the reasons why Rhode Island is known as the ocean state. Fledgling industry usually had a marine orientation.

Basic industries began to appear over the next 100 years. Shipbuilding, barrel making and tanneries are the more notable ones. Residential patterns were centered on town squares and streets developed in a grid fashion. By 1700 significant growth had taken place.

\footnotetext{
"Town streets became unattractive for residences: warehouses were built, basements were made into shops, over which the owners lived."(10)
}

This mixed-use type village was typical of the rapidly growing state.

Commerce was the catalyst for much of this growth. The transportation system the bay provided enabled growth within the state and throughout the region. This sparked a ten fold increase in the population from 7,000 in 1700 to 70,000 in 1800 . The commerce and manufacturing capabilities soon rivaled that of the mother country, England. Dynamic human involvement in this trade and transportation network within the coastal zone had its beginnings. 


\section{Revolution}

English businessmen aware of the competition complained. By 1770 a system of onerous fares and regulating laws emerged. These acts were designed to limit and suppress the manufacturing and trade of the colonies. Over the next six years united resistance to England emerged. The Continental Congress was founded, militias were raised and revolution was an open topic. On May 4, 1776 Rhode Island was the first colony to declare her independence from England. The colonists were concerned with continuity of law during the revolution. This was manifested by the inclusion of the following in the act of independence.

"Provided, nevertheless, that nothing in this act contained shall render void or vitiate any commission, writ, process or instrument heretofore made or executed, on account of the name and authority of the said King being therein inserted".(11)

This in essence validated the existing order of life. A new State and Federal constitution would enumerate and define the powers of the government.

The colonists were concerned with the arbitrary powers of the king. Especially when it came to private property. As a result, Article I, section 16 of the Rhode Island Constitution reads

"Private property shall not be taken for the public uses without just compensation." (12)

This same concern is also expressed in the United States Constitution. 


\section{Summary}

The purpose of this chapter is to establish a historical background of man's interactions with land. From ancient times to present day human development parallels land development. Choices concerning land-use involves man's perceptions of his total environment.

Decision making has changed markedly since early

man. The emergence of a legal system set parameters for man's activities. Activities were controlled in the form of regulations. Land development was incremental in nature and based on the utilization of functional systems in the coastal zone. The major determinant of land use was economic factors.

The dynamic evolution of Rhode Island's colonial history culminated with the codification of laws. Part of which contained private property rights. The new Constitutional form of government specifically enumerated legal power; in part a reaction to the evolution of political power in England. The operative assumption in England was the King possessed all power in society and laws were enacted to limit the Ring's powers. The converse became true in America and Rhode Island. The Rhode Island assumption is that individual rights are paramount except where specifically limited. This has led to a dilemma with inherent societal rights. In America, and in Rhode Island, laws and regulations are enacted to limit private property rights. 
"In England inherent societal rights

are paramount to property rights. (13)

This perception of land and property rights in

Rhode Island exists and is firmly entrenched and

accounts for the nature of existing land-use controls. 


\section{CHAPTER II}

\section{Land-Use Control $=$ R.I. Experience}

Economic forces are a significant determinant of land-use patterns past and present. Linkages among industrial employment, commercial and residential factors influence land-use patterns.

Land-use control in Rhode Island can be active or passive. Passive land-use controls have direct impacts on the location of future land development. The systematic location of transportation networks are excellent examples of passive land-use controls. Legislation in the form of regulatory performance requirements are active controls on land-use. Regulation is based on the inherent rights of government to exercise police powers. This subject will be our primary focus.

\section{Economic Forces}

Basic industries and commerce are significant determinants in land-use patterns. The early shipping and textile industries of Rhode Island exemplify this notion. Newport and Providence were busy seaports in the latter $1700^{\prime}$ 's and early 1800's. The early shipbuilding industry produced vessels used in trade and shipping. The industries grew and Rhode Island played a significant role in the triangular trade of rum, slaves and molasses. Later on the focal point became the Far East and the China trade. Ancillary services supported 
the shipping industry.

Craftsmen for sail making and iron workers for making hardware and rigging for the ships flourished. Foundaries, warehouses and boarding houses for sailors all effected the land-use patterns. (1)

Manufacturing was not new to Rhode Island. Rhode Islanders had long been engaged in processing the goods shipped in and out of Rhode Island. Eventually there was a gradual shift of capital from the shipping industry to manufacturing and in particular the textile industry. The industry grew rapidly using a combination of natural resources, technological innovations and mercantile skills. With the expansion of mills came the increase of population to work the mills and the dominant residential patterns was the mill village. Water, being the energy source, most mills were located next to rivers and streams.

\section{Requlation}

Regulation of industries was an accepted way of life. Taxes on goods shipped and rules over the use of water power predate the revolution. The legal system before the revolution was based on the Ring's charter and English law. A major point of the previous chapter was the operating assumption of power vested in the King for societies sake. Simply put, the evolution of English laws was the requlating and defining of rights and powers.

The American revolution brought constitutional 
government with specific enumerated powers. The underlying assumption of inherent societal rights vested in the Ring shifted to the domain of the individual and brought the ascendency of individual rights. The mechanics of regulation did not change. Regulation still defines and limits what can be done and remains adverserial in nature.

Specific government powers as taxation and the police power are inherent in the Constitution. Statutes authorize additional powers of government. Since the revolution many statutes or public laws have been enacted. More often than not; the law will regulate an activity. Even with numerous regulations placed; undefined, hence all encompassing, individual rights are viewed as sacrosanct. This probably accounts for the ubiquitous statement, "It's a free country and I can do whatever I want". This view is transferred to individual property rights. The lines of the battle were drawn. Government regulation versus individual rights. Development of policies to implement a regulatory statute is a key issue, to be discussed later.

The practice of regulating has effected passive and active land-use control in Rhode Island. During February, 1810 the R.I. General Assembly passed a law regulating a transportation network enabling creation of a toll road.(2) Enabling or granting authority is 
common in R.I. During October, 1841 the General

Assembly enabled Providence to control and regulate

land-use in the coastal-zone. (3)

In January, 1888 the General Assembly passed laws

to control utilities. (4) i.e. Narragansett Electric

lighting company, and the same year

"An act authorizing the town council

of the town of Westerly to make ordinances regulating the erection, enlargement, height, materials and removal of buildings".(5)

The regulation of land-use began to get more specific.

These examples evident the increasing tendency for state government to delegate land-use control through

regulation. In 1921 the new concept of zoning was endorsed.

\section{Zoning}

zoning is the main tool local communities have for land-use control. Zoning is a police power used in controlling the height, volume, and use of buildings, the activities on land and the density or number of people who may occupy the land and buildings. The idea of zoning conflicted with the all encompassing liberal view of property rights. This dilemma still exists and is constantly defined and refined by laws and judicial decisions. The significance of the concept is worth further focus.

In 1921 the General Assembly passed Public Law, Chapter 2069. This was Rhode Island's first enabling legislation for zoning. The justification and scope of 
the law is found in section 1 .

"For the purpose of promoting health, safety, morals or general welfare, the city council of any city shall have power in accordance with the provisions of this chapter within the limits of such city by ordinance to

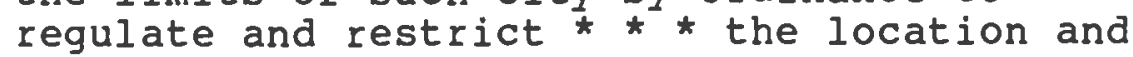
use of buildings, structures, and land for trade, industry, residence or other purposes. For any and all of said purposes said city council or representative council may divide the municipality into districts of such number, shape and area as it may deem best suited to carry out the purposes of this chapter; and within such districts it may regulate and restrict the erection, construction, reconstruc-tion, alteration, repair or use of buildings, structures or land. All such regulations shall be uniform for each class or kind of buildings throughout each district but the regulations in one district may differ from those in other districts. (6)

The law received mixed reviews. Some communities were quick to adopt it; others were slow.

Robert Whitten of Cleveland, Ohio was a zoning expert. On July 1,1922 he was hired by Providence to prepare a zoning plan. The trend of zoning urban areas was spreading rapidly across the country.

By January 1, 1923, 109 cities and towns in the united states had zoning regulations in operation. (7)

The Providence zone plan realized the radical nature of zoning and attempted to co-opt challenges by seeking a broad base of support in part by seeking input from concerned industry and organizations and requesting citizen participation. The grand fathering of existing land uses through non-conforming zoning, defused immediate challenges. Providence adopted the zone plan 
and it wasn't long before litigation arose.

Additional legislation and judicial interpretation help to mold and define current zoning laws in Rhode Island. Judicial decision has been significant in shaping zoning laws. The supremacy of government rights over individual property rights was upheld. The question of constitutional validity was addressed by the R.I. Supreme Court June 11, 1926 in City of Providence v. Stephen et.al. Early legal concerns centered on the reasonableness of zoning. To protect individual rights the laws could not be arbitrary or confiscatory. The inference for comprehensive planning is clear.

Eventually the Rhode Island General Assembly enacted general law section 45-24-3. The act required local zoning board to approach zoning comprehensively. The Rhode Island supreme Court affirmed this in Cianciarulo v. Tarro $1961168 \mathrm{~A}$ Zd 719. In part the court said

$$
\begin{aligned}
& \text { "we are of the opinion that the requirement } \\
& \text { set out in } 45-24-3 \text { that the zoning } \\
& \text { legislation conform to a comprehensive plan } \\
& \text { is mandatory and that strict compliance is } \\
& \text { required of a local legislature when it } \\
& \text { enacts a zoning ordinance". (8) }
\end{aligned}
$$

Outside regulations effecting the comprehensive plans have been modified by other land-use controls.

Other Land-Use Controls

The permitting process is the vehicle of land-use controls. Both local and state government use the permitting process. Building permits ensure the 
conformance with local zoning. Periodic inspection assures compliance of other local and state standards. A myriad of standards have evolved and are defined by performance measure. During the past 30 years there has been a significant increase in the number of required permits and a corresponding increase in higher standards of performance measures.

The 1968 permitting requirements of individual sewage disposal systems (ISDS), and the 1971 Wetland Act are examples on the state level permitting. Zoning and sub-division regulations typify the local level of permitting. The proliferation of necessary permits has been far reaching. Generally speaking, state permitting has been single function where as local permitting has been comprehensive in nature.

Most rural development require permits by both local and state government. In some cases, federal permits are also needed. This sequential and multiple level of permitting can be complex, confusing and costly for developers. This further enhances the adverserial role of government regulation. A more serious problem lies with the consistency and continuity of the local comprehensive plan.

State permits are issued for specific purposes. This narrow focus does not provide a method for coordination with comprehensive plans. The incremental adoption of state permit requirements has further 
exacerbated the lack of correlation with the community plan. State permits take precedence over local zoning or planning requirements. The impact of state permitting authority over previously local land-use decisions has effected community growth. To fully appreciate the dynamism of this interaction an explanation of the history of Rhode Island's local comprehensive community plan is in order.

\section{Summary}

The purpose of this chapter is to provide an insight into the development of land-use controls in R.I. Economic factors are a significant determinant of land-use patterns. Initial state regulatory control was concerned with commerce and industry. The evolution of our legal system has endowed the individual not society with inherent rights. Despite this government maintains certain rights. Zoning and the regulatory process are part of the police power. The possibility of a dichotomy occurs with state permitting and local comprehensive plans. 


\section{CHAPTER III}

\section{Comprehensive planning $=$ The Misnomer}

The theory of comprehensive planning and the reality of decision making is similar to an oil and vinegar salad dressing. When first combined and used they compliment each other. But when shelved and left alone they separate and become their own identity. A comprehensive plan is a dynamic entity which must continually be shaken and mixed with economic and political reality. Planning when separated from the reality of decision making is ineffectual. This chapter will briefly explain the evolution of, and some problems with, comprehensive planning in Rhode Island.

\section{History}

The concept of comprehensive planning is quite old. The Greek word agora and polis demonstrate this. The ascendancy of individual property within the U.S. and Rhode Island stullified the concept of agora and polis for 200 years. The zoning issue of arbitrariness resurrected this concept and brought it under the police power. Two months before the R.I. Supreme Court decision in 1926 upholding the constitutional validity of zoning the General Assembly authorized cities and towns to create planning boards. (Public Law 1926 Chapter 804) This law was well received by urban areas but apparently ignored by the rural area. In 1935 the General Assembly passed an act creating a state planning 
board (Public Law 1935 Chapter 2198) This board proved to be ineffective. The various elements of comprehensive planning needed a catalyst to coalesce and provide impetus.

Many elements combine to produce a comprehensive plan. Economic, social, and physical goals of a community are basic to a comprehensive plan. The physical goals center on land-use patterns and the guiding of future land-use. Functional systems such as transportation, police, fire, education, and utilities all help to shape the growth of land-use patterns, especially residential patterns. The nature of city life requires a comprehensive approach. Such urgency did not exist in rural areas. Despite its importance the practice of comprehensive planning is relatively new spurred on by the Federal Highway Act and the Housing Act of 1954.

After World War II the United States returned to a peace time economy. The economy grew and expanded especially in the housing and manufacturing sectors. Many of the returning servicemen used the G.I. Bill to receive low interest mortgages. The residential building boom was on, and the auto industry experienced rapid growth. These two facts influenced the federal government in the 1950's to undertake an ambitious housing and transportation program constructing highways throughout the country and providing state assistance in 
housing. The functional system of a national transportation plan greatly effected land-use patterns. Cognizant of need and affect, Congress authorized monies for planning on the local level.

The federal government initiated a local assistance planning program eventually known as the "701" program. Federal monies provided an incentive for the development of a community based comprehensive plan to include future land-use development. To continue to receive federal monies for transportation such plans were required. Eventually R.I. General Law 45-22 passed in 1972. The statue required establishment of local planning boards and was procedurally and substantively specific in its requirements and relationship to comprehensive plans.

When federal monies became available the former Rhode Island Development Council (RIDC) coordinated statewide planning programs. R.I.D.C. provided the expertise and assistance necessary for local comprehensive planning. Much of the emphasis was on local planning. One possible reason was the history of General Laws delegating the authority for land-use decision-making and planning to the local level. Certainly one root cause was the perception of individual private property rights.

Land-use decision making has historically gravitated to local government for several reasons. 
Local decision making authority is responsible to the electorate of the community. In practice

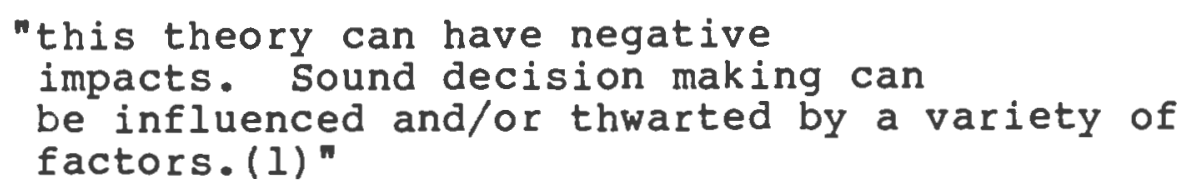

Legal authority for the planning and zoning of

communities rest with the local government. Citizen participation is apt to be more involved with issues concerning the local community. After all these are the people who live in the community. These issues meld and reinforce the inherent societal view of private property. The sense of fair plan and fair say is best conversed on the local level.

Rhode Island's 1,114 square miles have been divided into 39 autonomous land-use decision authorities. At the time of their creation a statewide guide plan was absent.

In 1965 the Statewide Planning Program (S.P.P.) was created. Among its goals was the development of a longrange state plan and program for land-use. S.W.P. provided technical assistance for the state Planning Council. This council consisted of numerous officials, elected and appointed, throughout the state. The council's mission was to establish broad guidelines and policies for future growth in Rhode Island. A technical committee comprised of state officials provides expertise to the council. One work product of the council is the state guide plan. The state guide plan 
consists of broad goals and recommended policies to guide growth. During this same time period of the 1960 's and 1970's environmental concerns became increasingly important.

Concerns over the environment persuaded Congress in 1969 to pass the National Environmental Protection Act (N.E.P.A.) This law had far reaching impacts. Greatly simplified it required resource use policies to be in harmony with environmental processes. Rhode Island's concern with the environment is also evident. In 1971 Rhode Island enacted two laws, both having major impacts. The Wetlands Act was single focused, requiring permits for building on, or altering an identified wetland. The other statute was much broader and required a comprehensive approach.

The Coastal Zone Management Act of 1971 established a council with significant powers within the coastal zone, especially seaward of the mean high-tide. Authority landward of the mean high-tide was specifically addressed, limiting land-use authority only in developments which were considered to have an impact on the coastal zone.

The underlying assumption in environmentalism is protection for the good of society. The presumption of inherent societal rights can, and often does, come in conflict with individual property rights. Environmental awareness was in its hey day. This awareness con- 
tributed to the enactment of encompassing and stringent regulations requiring government assent through permitting .

The growth of state and local planning tempered by environmental consideration was great during the 60's and 70's. Emphasis culminated with state-wide land-use legislation in 1976. The Statewide Planning Program was the architect of the bill. The proposed legislation was based on sound environmental consideration after an intensive and extensive research and study period. The plan was detailed and provided options for growth throughout the state.

Governor Noel submitted the 138 page bill to establish a state land-use plan in March, 1976. The bill was controversial from its outset. Several communities saw it as an usurpation of local control of zoning. After many public hearings the bill never came out of committee. The next year Governor Garrahy resubmitted a revised bill of 119 pages. Changes included a new name - the Land Management Bill, and an attempt to allay the local fear of imposition of state power into the local community. After many public hearings it became apparent the bill would not succeed. Communities saw the Land Management Bill as a threat to their own land-use decision making authority.

\section{Aftermath}

Zoning was slowly adopted by R.I. communities, and 
in many cases preceded the development of a formal comprehensive community plan. This is similar to putting the cart before the horse. The same analogy applies between the local community plan and the state guide plan. Most communities had developed their plan in the absence of guidance by an overall state plan. This convoluded evolution of zoning, and planning, has produced a defacto approach of incrementalism. This is further compounded by state regulation.

The incremental nature of single-function regulation by the state contributes to an incremental rather than a comprehensive approach to land-use. Communities also contribute to incrementalism, apriori policies of 39 autonomous zoning and planning boards do not lend itself to rational land-use development on a state wide level.

The attempt to establish basic planning precepts failed. The work product of the statewide planning agency, the land management bill, was defeated. One result from all the planning efforts of the 60's and 70 's was the establishment of a network of professionals in and out of the planning field.(9) One product of the land management bill was the publication of the state Land Use Policies and Plan. This 250 page document established land-use goals and policies and served as the basic source for the Land Management Bill.

The text, written by the Statewide Planning Program, was the first attempt to unify or coordinate 
statewide control of land-use. Many agencies, administrators and planners were greatly disappointed when the 1 and management bill did not succeed. The bill was viewed as a means of correcting the disjointed, incremental system of planning that had evolved. As we shall learn, one state council has quietly adopted a comprehensive system of land-use control. 
The historical analysis, presented in part one, provides a framework to examine the management plan for the Salt Pond region. Initial discussion will center on authority of the Coastal zone Management Act (CZMA) and development of policies for the Coastal Resource Management Council (CRMC). Insights to the creation and development of CRMC will explain the underlying rationale for the salt Pond Special Area Management Plan (SAM Plan). The authorities, boundaries, and policies of the plan are among the strongest expounded in government. A narrow focus of land-use control within the plan will be examined in greater detail. A major contention is the appropriateness of the policy-making process. Decisionmaking processes are seen as bureaucratic rather than legislative. The phenomena of conflicting criteria in legislation has "left a significant part of the actual determinational of policy in the hands of the administrator"(1), to the exclusion of operative forces. The Resource Center developed policies having a specific interest orientation. "Interest groups sometimes develop great skill in persuasion through partisan analysis. (2) Problems identified result from a structured analysis to support ecological considerations. Finally, a conclusion with recommendations are made. 


\section{CHAPTER IV}

The Rhode Island Coastal Zone Management Act (RICZMA)

In the late 1960's an eighty-seven member study commission assembled to examine overall policy and planning for Narragansett Bay and the coastal zone. There were many public hearings held, the results manifested themselves in legislation submitted in 1969 to the General Assembly. The bill was submitted by Rep. John Lyons of Tiverton and Rep. Skiffington of Woonsocket. The bill was strong in its powers and proposals; in effect creating a council to establish policies and plans throughout Rhode Island's coastal region. The council regulates policies and plans through a permitting authority utilizing cease and desist orders. The strength of the law was due in part to the era in which passage occurred.

The national and state mood of the late 1960's and early 1970's was of increasing environmental concern. This concern produced a strong law. There are nineteen sections to the RICZMA(I) ranging from legislative findings 46-23-1 to appointment of sub-committees for contested cases presented to the council 46-23-19. The legal strength of RICZMA lies in section 46-23-6, power and duties and in section 46-23-7, violations. Section 46-23-2 establishes the Coastal Resources Management Council (CRMC). 
The CRMC consists of seventeen members. These members are appointed by the Governor, the Lt. Governor and the Speaker of the House of Representatives. Various criteria are used for the selection of the council, these include: population, elected officials, coastal communities representation, the general public and ex-officio, the Director of the Department of Environmental Management (DEM) and the Director of the Department of Health. The senate has the power of advice.

Membership on the council has come under political and judicial scrutiny in 1986. An amendment in 1985, limits the number of times a member may serve on the council to two successive terms. Approximately onethird of the current council has served since the establishment of CRMC, providing continuity of goals, plans, and policies. With tenure now limited, the direction of CRMC and its consistency could shift.

The curious criteria in the selection of members is probably unique to Rhode Island, given its small size, large relative coastline and numerous coastal communities. Oddly enough, private industry - in particular the oil industry* - or environmental or nature groups are not mandated representation. But as we shall see, both groups are, in fact, represented and

*Port of Providence major port in Narragansett Bay 93.58 of import are petroleum based 1976 CRMC report 1981, p. 175 . 
greatly influence policy of the CRMC.

Section 46-23-4 deals with quorum and the necessary vote needed for action. A seventeen member council is a large regulatory body. In order for a quorum, slightly over half the council or nine members must be present. A majority of those present is needed for required action. This means as little as five members can set policy and regulation out of a seventeen member council. This represents less than one-third of the fully seated council. With such a small vote needed for action it is critical members are informed and are timely for their meetings.

The appointing authority for CRMC members has been called into question. On appeal before the R.I. Supreme Court is the constitutionality of eight legislative appointments to CRMC. If this case is sustained the organizational membership of CRMC could change significantly. In any case; CRMC is being closely examined by judicial, legislative, and as we shall see, executive authorities.

\section{Policy Development}

The management council has broad powers in policy making, implementation, and the quasi-judicial power of policy interpretation. During policy development CRMC exercised considerable freedom in describing to what extent it would address specific issues.

After the enactment of the RICZMA the CRMC was 
slow in promulgating its policies and regulations. This is understandable considering the scope and magnitude of its authority and the frontier setting nature of CRMC. Another reason to be considered in its slow start-up is bureaucratic in nature. The CRMC was created but not significantly funded.(2) The council was to utilize the Department of Natural Resources (DNR) now (DEM) for staff support. But DNR did not get any funding for this assistance. Understandably there was friction initially growing out of this funding problem. Also the mandate to coordinate local, state, regional and federal agencies and private agencies set up a jurisdictional battle. Resulting in is a new agency with broad powers and no staff using the finite resources of existing agencies and possibly usurping their jurisdictional and bureaucratic powers. These problems were mitigated with the enactment of the federal CzMA of 1972. The national CZMA provided monies for much of CRMC functions, but it took time for the federal support to become available. By 1974 only two sections of the CRMC plan had been established. These concerned barrier beaches and the ship to ship transfer of oil.

Council membership includes a registered lobbyist for the oil companies, who also served as secretary of the CRMC during much of its policy formulation stage. The secretary is elected from among the councils membership or staff. The duties of this position are 
not clearly defined or identified in the RICZMA. In the absence of such, the first person who holds this office sets the parameters of his duties. Let us now turn to a brief history of the development of the policies and regulations of the council.

Professional lobbyists are known for their friendly persuasion. With the significant oil imports of Narragansett Bay it is important for an oil company to be heard. Some people would argue there is an inherent conflict with a professional lobbyist, especially as secretary and a voting member of a council with regulatory power over their industry. A student investigation into this apparent conflict was conducted and the lobbyist was seen as an important member and seen as a facilitator; having great knowledge of the oil companies, oil transference procedures and being able to assist in an emergency, if an oil spill occurred by providing needed equipment. (3)

\section{Lightering Policy}

The process of lightering is an important and regular practice in Narragansett Bay. Lightering is when oil is transferred from one ship to another for the purpose of making the ship lighter and in effect reducing the amount of water necessary for the ship to sail. This process became more common after the 1974 oil embargo with the resulting advent of large oil tankers. The vast majority of Narragansett Bay shipping 
is petroleum based and in order for large tankers to make it to the storage terminals at the head of the bay this lightering process must occur. This process is conducted in state waters, therefore, the Coast Guard does not have federal mandate to cover lightering. Rather the Coast Guard enforces the regulation promulgated by the CRMC. Coast Guard and CRMC policies are substantially the same.

Procedurally the Coast Guard regulations were more stringent. Naming type of materials to be used specifically and the process in which oil transference should be conducted. This could be attributed to the semi-military nature of the coast Guard or it could be the implicit wish of the CRMC not to hamper the oil companies. Other interesting policy concerning lightering follow. Oil lightering was one of the first policies developed by CRMC.

There are designated anchorage areas for the lightering of oil. But there is an apparent disclaimer to this in section $D$ under polices and regulations found in the RICRMP. (4) Under section 630-3-2 vessel to vessel transfer it reads D. Bunkering and lightering: "Nothing in the foregoing regulation should be construed as to prohibit the function of bunkering vessels or when a demonstrated need is shown, the lightering of vessels at a place other than the area designated in these regulations. Such demonstrated need should be evaluated 
by the Council who is authorized to set temporary regulations for such procedures".

The section is nebulous. It does not define the parameters of demonstrated need and it does not indicate if the council's evaluation is before or after the fact. Also, it is ambiguous - it doesn't say if these temporary regulations are in addition to or are instead of existing regulation.

New oil transference procedures are currently being written by the Department of Environmental Management. Recently the state received $\$ 5,000,000$ federal dollars to conduct a study of Narragansett Bay. A brief review of the proposed regulations indicate detailed and specific procedures for oil transference. Two implications exist. The regulation for oil transference published by CRMC are viewed as inadequate and secondly, the money was channeled to DEM, a department under direct control of the governor. The portent of the shift in funding is still unclear, especially when Narrangansett Bay is considered to be clearly under the jurisdiction of CRMC. For many years CRMC was the major recipient for funding related to the coastal zone.

By late 1977, with the infusion of federal funding, all policies and regulations of the coastal zone plan had been formulated. The broad goal of oil transference is controlled but substantive specifics are missing. The trend of being influenced by helpful friends and 
interested parties, i.e. oil lobbyist, is introduced during these first policies.

Coastal physiographic features and activities under council jurisdiction are subjected to these regulations. These regulations were manifested in March of 1978 with the publication of the State of Rhode Island Coastal Resources Management Program (RICRMP). The document has since been revamped into separate functional areas. They include a three part document describing authorities, procedures and jurisdictions. Other elements of the Rhode Island program include the Energy Amendments of 1979; Management Procedures; Rights of Way to the Shore; and Special Area Management Plans for selected areas. It is the latter we are concerned with, notably the Salt Pond Management Area.

The early policy issues before CRMC helped to establish precedence and procedure for dealing with future issues. There appears to be a paradox: broadly defined goals reached via specific and selective objectives. This same prospectus could apply to the environmental orientation of CRMC's policies.

\section{Environmental orientation}

The current chairman of the council in 1986 is considered to be a champion of environmental causes. The genesis of the CZMA is steeped with environmental concerns. Legislative finding creating the CRMC, is typical compromise language of a democracy. 
46-23-1. Legislative Findings. Creation

"The general assembly recognizes and declares that the coastal resources of Rhode Island, a rich variety of natural, commercial, industrial, recreational, and aesthetic assets are of immediate and potential value to the present and future development of this state; that unplanned or poorly planned development of this basic natural environment has already damaged or destroyed, or has the potential of damaging or destroying, the state's coastal resources, and has restricted the most efficient and beneficial utilization of such resources; that it shall be the policy of this state to preserve, protect, develop, and where possible, restore the coastal resources of the state for this and succeeding generations through comprehensive and coordinated long-range planning and management designed to produce the maximum benefit for society from such coastal resources; and that preservation and restoration of ecological systems shall be the primary guiding principle upon which environmental alteration of coastal resources will be measure, judged, and regulated." (5)

The findings say preserve and conserve and to utilize and develop. These terms appear to contradict. CRMC has interpreted the statue to allow development only in conformance with strict environmental standards. To preserve, protect and develop sends mixed signals. The preservation of ecological systems is the hallmark of most environmentalists and is based on inherent societal rights. To develop and utilize is language builders or developers would use, their cause is steeped in individual property rights. Yet both are found in the legislative finding. The dilemma is ironically linked to a paradox. This paradox is the philosophical dichotomy of man's interaction with his spatial environment. Put simply; man is considered a 
part of his environment or is he to be viewed as a separate force acting upon his environment. Of course, there are extremes to both perspectives, but one's approach to this philosophy in large measure shapes his findings.

A Close Relationship

The University of Rhode Island (U.R.I.) is world renown for its curriculum in oceanography and related fields (i.e. ocean engineering, marine biology, marine affairs, etc.). This vast and significant resource has worked closely with CRMC. The Coastal Resource Center (CRC) is part of the Graduate school of Oceanography at U.R.I. The C.R.C. has provided expertise in scientific areas and researchers have contributed much in the form of policy development, having written basic documents for and undertaken joint studies with the C.R.M.C.

"In fact, during its early years the Coastal Resource Center at the U.R.I. had to rely upon sea Grant funds and direct support from the Graduate school of Oceanography to carry out its responsibilities to the CRMC." (5)

Relationships between regulatory councils and a public institutions are not without precedent. But few have worked so closely sharing various sources of funding .

Employees of the CRC usually have advanced degrees in a hard science area, mostly with a marine 
orientation. A natural inclination for researchers with science backgrounds is to analyze in terms of hard scientific data. The orientation of CRC towards the natural sciences and the mixed mandate in the legislative finding has shaped CRMC policies. CRMC has taken significant steps to protect ecological systems in the coastal zone. Preservation of these ecosystems, to include the watershed, has caused the landward boundary to expand to contiguous areas. The CZMA has been amended several times (table 4-1). Most of these amendments have been sought by CRMC. Subtle, yet significant, changes in the description of powers and duties have increased areas under the CRMC control. The new description justified a comprehensive planning approach to areas several miles inland. Potential and actual land use within the region came under council scrutiny.

Land-use planning, in detail, is now in place within the salt Pond region, other areas are soon to follow. These regional areas are known as special area management plans, commonly referred to as SAMPs. This occurs at a time when federal funding is decreasing while CRMC is enlarging its scope of authority and responsibility. The upshot is CRMC already has a dismal record of enforcement. (7) These facts beg the question; what good is a plan unless it is used? 


\section{TABLE $\underline{4-1}$}

\section{AMENDMENT TO THE 1971 COASTAL ZONE MANAGEMENT ACT}

CHAPTER 46-23 - COASTAL RESOURCES

MANAGEMENT COUNCIL..............Added, 1971

Section

46-23-5. Expenses of members..........Amended, 1974

46-23-6. Powers and duties.............mended, 1976, 1977,1984

46-23-7. Violations.................mended, 1973, 1976,1977 , 1980

46-23-13. Application and hearing fees..Added, 1973

46-23-14. Expert testimony.............Added, 1973

46-23-15. Federal and interstate relations...............Added, 1973

46-23-16. Length of permits, licenses and easements (formerly

Fifty year permits)........Added, 1973 Amended, 1976

46-23-17. Annual progress report on rights of way.............Added, 1977

46-23-18. Activities permitted without permission of council.......Added, 1983 


\section{Verification}

CRMC's control of land-use in barrier beaches was upheld by the R.I. Supreme Court in 1981. Sebatian Milardo v. Coastal Resource Management Council. The case concerns the granting of a permit to build a house with an individual sewage disposal system (ISDS) on Winnapaug Pond in Westerly.

The court saw three issues needing clarification and judicial decision. (1) Had the state the power to regulate the use of his property; (2) is it valid to delegate this power to the council; and (3) was the exercise of this power by the council correct in the case. The court upheld CRMC on all three issues, reinforcing the powers and jurisdiction of the council. Another case concerning ISDS was about to appear before the council.

Foster Cove is located in Charlestown, R.I. Located behind a barrier beach it is considered environmentally delicate. A fifty-nine lot sub-division was scheduled to be built there. There are no sewers and an ISDS is required. In order to build several state permits are needed, including D.E.M. and CRMC. D.E.M. is mandated to approve where minimum ISDS standards are met. Individually each ISDS would pass but collectively they would adversely effect the ecology of the cove. D.E.M. was in the ironic position of having to argue before CRMC against their own 
approval.(8) The comprehensive approach is within the legal mandate of the CRMC.

The Foster Cove development received limited approval by CRMC; only eight to ten houses have been built with strict adherence to stipulations placed by CRMC. The requirements include the installation of a specialized denitrification ISDS. These systems are expensive and are priced around $\$ 10,000$. Also the systems must be monitored causing an additional ongoing expense. The additional expense scaled back the original development plans for Foster Cove.

Broad goals such as protection of watersheds from harmful pollution is generically appealing and without detraction. The selective recognition of specifics to support the goal may have some problems. The next chapter will examine this occurrence in greater detail.

\section{Under Fire}

A powerful council and politics are inseparable. Recent procedural questions have risen concerning the council.(9) A conflict between the Governor and the CRMC has surfaced in the media.

Staff support is no longer provided by D.E.M. Hence, CRMC has requested funding for its own operation. Their rationale is they can be more effective and efficient if the staff support did not have dual allegience to the Director of D.E.M. and to CRMC. The request was approved but ironically it has not worked 
out as planned.

Governor Diprete is in a dispute with the CRMC. Philosophically he questions whether the commissions boards or councils should have the significant policy making, operational control and quasi-judicial power the CRMC has assumed. Reeping with this perspective he has been slow on releasing appropriations for CRMC staff. The lack of money for the CRMC staff has hampered the administrative processing of CRMC policies.

\section{Summary}

The environmental awareness of the early 1970 's produced a council with sweeping powers in the coastal zone. The council has been a strong advocate of environmental considerations; in part due to legislative mandate, and the way policies were developed and to the close association with parties having obvious goals and hidden agenda. The legality of CRMC's ISDS decisions on barrier beaches have been affirmed but in recent years judicial questions and executive funding have begun to undermine CRMC's authority. 


\section{CHAPTER V}

This chapter will be an analysis and critique of the Salt Pond Region Special Area Management Plan (SAM Plan). The SAM plan has a rigid environmental orientation and justification due to the backgrounds and philosophical approach of its authors. The plan is a comprehensive approach towards management but is not balanced against economics, political and social needs of the communities and the citizenry of Rhode Island.

The SAM Plan

The SAM plan is based on eight broad goals (see Table 5-1). The plan provides greater detail and compliments policies, standards and regulations promulgated in the Rhode Island Coastal Resource Management Program (CRMP). Required in the plan is a special exception for any action not conforming to policies of the plan. In several areas the plan significantly expands the previous geographic jurisdiction of CRMC, most notably in Charlestown. The one hundred page, seven chapter plan has superceded established local land-use discretion and replaced it with an attempt to coordinate state regulatory permitting.

The plan is two years old and includes twenty percent of Narragansett, thirty percent of South Kingston and forty percent of Charlestown for a regional area of thirty-two square miles. Recently the town of 


\section{TABLE 5-1}

\section{THE GOALS OF THE PLAN}

This Special Area Management Plan is based on eight goals.

1. To maintain the exceptional scenic qualities of the salt pond region and a diversity in the mix and intensity of the activities they support.

2. To prevent expansion near areas of the salt ponds that are contaminated by potentially harmful bacteria or eutrophic conditions.

3. To ensure that groundwater will be unpolluted.

4. To preserve and enhance the diversity and abundance of fish and shellfish.

5. To restore barrier beaches, salt marshes, and fish and wildlife habitats damaged by past construction or present use.

6. To prepare a post-hurricane restoration plan.

7. To maintain point Judith harbor as a commercial fishing port and provide for expansion of port facilities.

8. To create a decision-making process appropriate to the management of the region as an ecosystem. 
Westerly has requested to be included in the plan. (Westerly will not be part of this analysis.)

The plan calls for coordinated management of growth, especially residential development. The plan cites 5,570 housing units within the region, with a potential of local zoning allowing three times more housing and seven times more people in the region. This unlikely development is seen as problematic.

Recommendations in the plan call for CRMC approval of functional systems. The extension or creation of roads, water and sewer systems are normally the prerogative of a local community. These systems are key in directing and determining growth patterns. Within the SAM plan region a permit is reguired if the town wants to initiate any of these functional systems.

The plan is supposed to compliment local zoning but compliment could be considered a euphemism. In reality the plan overrides the primary land-use decision-making tools; namely, community functional systems and local zoning. According to the plan approximately fifty percent of undeveloped land is privately owned and zoned for residential use.

The plan projects significant growth for several reasons. The desirability of the area is rated high because of the high quality environment and exceptional beauty.

There are a few individuals who own large parcels 
and the economic incentives to subdivide these holdings are increasing in order to avoid spiraling tax bills. This argument is tempered with the Farm, Forest and open Space Act allowing property owners to enroll in a program requiring property taxation at current use, i.e. vacant land, rather than highest potential value, i.e. residential housing lots.

The plan is premised on growth leading to environmental and ecological damage to salt ponds, ground water, fish and shellfish nurseries. Potential development is predicted as altering aesthetic and recreational qualities of the region. Most development is viewed as negative and contrary to maintaining the regions current pristene nature. The authors of the plan focus on effluents from septic systems contributing to ecological alteration.

An Individual Sewage Disposal System (ISDS) is key to the argument. Since 1969 all ISDS must meet minimum engineering and construction standards published by D.E.M. These standards have been amended and approved six times since 1969. The SAM plan views ISDS as a culprit in eutrophication and bacterial contamination. All ponds experience these natural processes and the question should center on the extent and degree of these processes. Unfortunately, the plan uses inadequate data to support its hypothesis.

Man's acceleration of eutrophication by ISDS 
increases nutrients and bacteria causing a rapid growth of algae. This depletes oxygen levels in the water, thereby changing the ecology of the pond. The amount of tidal flushing, temperature, currents and salinity also affect eutrophication. Lawn fertilization is surmised 0 be a factor in eutrophication. Nutrients from fertilizers can leach to the salt ponds or come in the form of surface runoff.

Bacterial contamination in the form of fecal coliform is a problem produced by domestic animals and failed ISDS systems and are the primary cause of high fecal coliform counts. An ISDS is judged to have failed when waste water is no longer absorbed below ground level. By any standard, this an extreme case of failure.

Scientific data indicates a great variance in eutrophication and bacterial contamination depending on the intermixing of current, temperature, tides and salinity. In any case, the dynamics of salt ponds are influenced by type and intensity of land-use. This in essence is the justification for the SAM plan placing restrictions on types and intensities of land-use. The 1977 Amendments to the CZMA broaden the CRMC jurdisdiction to contiguous areas. (1) The wording of this legislation has been interpreted liberally and provided the expansion of coastal boundaries for two primary reasons. A vacuum existed for comprehensive 
planning and second, the inherent nature of bureaucracy to expand. Other factors shaped and molded policy development to an environmental orientation.

Policy Development

Early policy formulation established precedent with structural biases. To achieve stated goals CRMC relied on interested parties to establish objectives leading to the goals. The objectives were selective and not balanced against all segments of society. For instance, the policy language for oil transference could be viewed as providing interpretive flexibility to oil lightering and bunkering. An alternative would have been the full adoption of the Coast Guard procedures for oil transference. The main interested party in CRMC policy development were environmental groups. Their influence has greatly shaped policy and regulation and assisted CRMC in establishing land-use planning methods.(2)

The legislative findings say the "preservation and restoration of ecological systems shall be the primary guiding principlen. The inference is other principles are operative, such as to develop and produce the maximum benefit for society within the coastal zone. In formulating its policies the CRMC focused on the guiding principle to the exclusion of others. There is little or no active planning to produce a range of tangible benefits to society beside maintaining the status-quo of the natural environment. Environmentalists would argue 
this is the tangible benefit; the preservation of a natural environment. Development is viewed as hostile to the environment. Clearly, the philosophical perspective of policy formulation is that man is not considered a part of the natural process. The ecology of the coastal zone and contiguus area are paramount to man's interaction with his environment. Therefore, any development must be strictly controlled so as not to alter the existing ecology. There are problems with this view.

Is man part of the environment or is he viewed separate from the environment? The biases of one philosophical approach over another is not an equitable or a solid foundation to build a comprehensive plan for the coastal zone. A preferred methodology would be to incorporate both approaches utilizing legislative rather than bureaucratic means. It could be argued that the SAM plan uses both perspectives but rationalists would argue negatively. The current regulatory permitting systems puts the builder, developer or homeowner in an adverserial relationship with the SAM plan. The burden is to prove no damage or alteration to the ecology of the coastal zone. This belies the fact the coastal zone, and salt ponds in particular, are a dynamic environment that experience annual change. Their ecosystems are just recently coming under intensive and extensive research, and this research is time sensitive. 
Incomplete base line data on ecosystems thousands of years old and ever changing is not a firm footing to build sweeping land-use decisions by an appointed regulatory council.

\section{Critique of SAM PIan}

The SAM plan was prepared for CRMC by Stephen Olsen and Virginia Lee. Both are researchers for the Coastal Resources Center (CRC) which is a part of the Graduate School of Oceanography (GSO) located at the University of Rhode Island (U.R.I.) Bay campus. As previously mentioned, the CRC has had an extremely close working relationship with CRMC. Both groups are environmentally oriented and to a large measure predetermined the outcome of the plan. Institutional factors also guided the plan to its unchallenged outcome. They include bureaucratic networking and the phenomena of "passing the buck", in difficult and possibly unpopular, local political decision-making.(4) The mix of these operative factors has produced an environmentally sound comprehensive plan adopted by an appointed council that has the full effect and force of state law. The abdication of land-use decision making authority, to an appointed council, guided by interested parties, renders usurpation of local land-use decision-making a moot issue. Rather this critique will analyze an attempt to verify the SAM plan policies. A discussion of land-use decision-making and other related policy issues 
will be discussed in the final chapter.

What's the question

To a large extent what is the question, and who answers the question, determines the answer to the question.

Section 120. Origins of the Plan provides the genesis of the questions asked. Scores of residents of the Charlestown area established the issues, they essentially are concerned with environmental degradation of the area.

\footnotetext{
"What's the question? is to a large extent dependent upon the researchers skill, interest, and sensitivity in understanding the problem". (5)
}

The strong enviromental orientation of CRMC and the researchers biases framed the question with an inevitable answer. Preservation of the estuarine ecology is the jusitification for rigid council control of land-use. An analogy may help in understanding the point.

Currently Pettasquanscutt Cove and its surrounding region is about to come under the control of a similar SAM plan. The inlet and much of the cove is in Narragansett. During the late 1950's the town of Narragansett asked the Army Corp of Engineers to develop a plan to protect Pettasquanscutt Cove and control flooding. In 1960 the Corp responded with a proposal including dredging, building of a breakwater and a marina. Such a proposal now would be highly ridiculed. 
Time has a way of changing priorities. When engineers were asked to protect the cove they provided a solution with an engineering focus. Similarly when CRC was asked to prepare a plan their pre-disposed biases(6) produced a stringent environmentally oriented plan based on selective and incomplete data.

\section{Data Analysis}

The policy formulation for the SAMP has been influenced by the development process, the researchers biases and the questions asked. Hence the goals of the plan are narrowly focused. Data used to justify the goals of the SAMP is scientific with many studys from U.R.I. cited. Since the thrust of this paper is landuse, an analysis of the data used to justify land-use control will be presented. (See Appendix C)

Initial examination of the SAM plan and supporting data proved to be challenging. The documentation and scientific analysis overwhelms the reader. But after rereading several times subtle statements begin to stand out. An alarmist view is taken on several issues. In addition, contradictory statements are made, old data is used and extreme examples as presented as if representative, this misleads the reader. A discussion of these facts follows. Found in the Appendix $\mathrm{C}$ are the pages in question which are used to justify the expansion of land-use control in upland areas.

On page eight, section three, the topic of 
groundwater pollution is discussed. It mentions the necessity of installing water supply systems due to bacterial contamination in private wells. On page twenty-eight, section three, says "Properly designed and sited septic systems effectively treat the bacteria in domestic waste." D.E.M. regulates the design and siting of septic systems so bacterial contamination from new ISDS is a moot issue unless there is an ISDS failure. The standards used in the SAM plan for ISDS failure is extreme. "A septic system is judged to have failed when the wastewaters are no longer absorbed below ground level." This occurrence is problematic with ISDS built prior to 1969. A random telephone survey to septic systems cleaners indicates emergency service is normally on older systems predating D.E.M. standards. Symptoms like poor flushing or draining prompt people to pump out their system prior to total failure. In addition, annual maintenance of systems is increasing.

To buttress the SAMP argument for residential down zoning old data is presented and information is provided which is contradictory and confusing. To document the movement of fecal coliform from ISDS effluents the plan uses a study from 1923. Surely more recent data could be gathered concerning water saturated soils and soils with high-permability. There is also an apparent contradiction of how quickly groundwater moves through the soils in the region. 
On page twenty-three, section $B$, paragraph two, the distinct impression of rapid groundwater movement is given and that gravelly glacial outwash soils that predominate the region are susceptible to nitrate enriched groundwater that "flows toward the ponds at speeds ranging fron one to four feet per day". Yet on page thirty-nine, section six it states, "the slow rate at which groundwater moves towards the pond suggests that the impact of much recent development in the watersheds is not yet being expresesd as increased annual loadings of nitrate to the ponds." Using the very same soils, an attempt is made to design an argument to further biased objectives. The reader is left wondering how the same soils can leach nitrates quickly yet restrict the collection of data which would support an unfavorable inference. The inference being modern ISDS do an adequate job in controlling wastewater in groundwater.

Soils within the salt Pond region are the justification for using a water study conducted in Long Island, New York. It is true both soils are similar but the similarities stop there. The majority of surburbanization on Long Island took place during the $1950^{\prime}$ 's and 1960 before the advent of improved standards for design and construction of ISDS. In addition, residential patterns vary considerably and are mainly year round rathern than seasonal. 
The physical and social characteristics of Long Island is significantly dissimilar to Charlestown, South Ringston and Narragansett. Using a household on one acre of land with 15,050 square feet of lawn or garden is inappropriate for several reasons. A windshield survey indicates the size of attended lawns within the salt pond region are much smaller. The periodic use of fertilizer is associated with a higher levels of income. The median income level of households in the salt pond area is significantly lower than median income levels of Long Island (see Table 5-2). The combination of different residential patterns, older ISDS and dissimilar physical, i.e. road networks, and social characteristics found on Long Island renders any comparisons inaccurate. Page thirty-three, table 3-3 and figure 3-5 uses the Long Island study as a basis for predicting the amount of inorganic nitrogen in groundwater within the major salt ponds. This table is most likely inaccurate and does not represent either the amount or the distribution of inorganic nitrogen. The collection of field data is also misrepresented.

The field data collected indicates there is a nitrogen problem within the salt pond region. The vast majority of the testing is south of Route 1 (see figures 3-4 and 3-6). The majority of housing units in these areas predate ISDS standards of $1969(7)$. Two factors are operative here, ISDS standards and 
$\underline{T A B L E} \underline{5-2}$

MEDIAN INCOME ON COUNTY LEVEL

COUNTY
*WASHINGTON COUNTY, R.I.
** RING
**QUEEN
***NASSAU
$\star * \star$ SUFFOLK

1979

$\$ 20,859$

14,604

20,506

28,444

24,194

*Washington County is rural and suburban in nature

** King and Queen counties are closest to New York City. The income are reflective of urban inner city incomes.

***Nassau and suffolk counties are more rural and suburban in nature.

Source for Median Income

1980 U.S. Census Bureau

County and City Data 
housing density. Page thirty-five, section three states "base density for self-sustaining environments has, however, already been exceeded in many areas close to the ponds where houses are crowded together on $1 / 8$ acre to $1 / 4$ acre lots." This high density, antiquated ISDS, and pond proximity will expectedly produce high nitrogen levels.

Both zoning in the area and ISDS has been upgraded. The data collected and the problems resulting from these older developments should not be transferred to new developments. The new standards in the plan are based on data collected from substandard zoning and ISDS. It is incorrect to apply deficient standards utilized in older developments to justify stringent development control based on more modern and higher standards of zoning and ISDS.

Unfortunately, the plan uses alarmist examples in an off hand manner. On page thirty-one, figure 3-4, a study cites milligrams of nitrate nitrogen per liter (mg/l) taken seasonally from groundwater of two hundred residential wells. There are several problems with the data. The narrative addressing the data uses part per million by weight (ppm) but the data used to support the contention of high nitrates is in milligrams per liter which apparently is the same as p.p.m. This leads to confusion when interpreting the data. The next problem is in the extreme example given. The federal health 
limits for nitrates is 10 p.p.m. The report goes on to say "Higher concentrations are considered a public health hazard and can cause infant cyanosis, a condition where nitrogen rather than oxygen is transported by the blood and the child suffers oxygen starvation which, in severe cases, can lead to brain damage or death. (8) The use of such extreme examples is inappropriate and is used to startle the reader and to sway judgement. The field data collected is in milligrams per liter (mg/ 1 ) and it overwhelmingly indicates concentrations less than 5.6 p.p.m., with one small area in excess of $5.6 \mathrm{mg} / 1$. This information suggests the concentrations are well below federal health limits.

The data is constructed using a worse case scenario. Table 3-5 (page 37) projects nitrogen loading to the salt pond watershed. These projections are based on faulty assumptions. Determining potential building sites utilized in the prosection a bias assumption was used "lots of less than applicable zoned lot size were counted as buildable lots in cases where lots were in separate and non-contigous ownership. Ostensibly this is to account for lots with "grandfathered" zoning rights. To assume all of them would be developed is tenous. Since ISDS and well permits may be necessary this assumption is weak. To presume building on developed lots with enough space for an additional building permit is also faulty. The data presentation 
is prejudicial to maintaining the current ecology of salt ponds.

\section{Ecology of Salt Ponds}

The ecology of salt ponds are thousands of years old and ever changing and the various perceptions and use of salt ponds is also old and ever changing. Early Rhode Island settlers used to drain marshes for pastures(9). Salt ponds were used for trading and acqua-culture purposes(10). Man's perception was to use this environ to his advantage. Often the results were unexpected. The attempt to enhance brackish water fisheries, i.e. oyster and white perch, by stabilizing breechways ultimately lead to the decline of these fish. The breechway altered the ecology of the pond and common fish stocks were replaced by species such as quahogs, bay scallops and winter flounder. The winter flounder is curently viewed as an important recreational and commercial fish.(11) The perceptions of man's use of the salt marshes and ponds can change within a short period of time.

In 1973, Dr. Scott Nixon, a professor of oceanography was speculating the possibility of using salt marshes as "living filters for sewage where nitrogen and other nutrients could be taken up and held by the grass, then later released slowly as the plants died, decayed and were carried into the estuary to serve as a rich source of detrital food."(12) such 
speculation runs contrary to current perceptions.

There are a great number of variables involved in the ecology of salt ponds. The dynamics of these variables are complex and not fully understood, especially in terms of scientific analysis. The impacts of wastewater disposal on estuarine systems is still under study and only educated guesses can be made as to its future impact.

The SAM plan development management strategies are based on "a preponderance of evidence to draw responsible conclusions regarding the future of the ponds."(13) There are deficiencies with this approach. The evidence gathered is scientific in nature. The components which comprise the scientific analysis are not completely understood so any prediction is at least questionable.

Secondly, the analysis is conducted during a specific and limited time period. The ecosystem within a salt pond is thousands of years old, and in a constant flux, rendering relative baseline data useless. Therefore, any comparisons are useful but only applicable for a limited duration.

Most importantly, the scientific data does attempt to measure man's chemical interaction with the coast zone but does little to measure all around use of the environ. Implicit in scientific studies are a single focus analysis excluding outside unrelated events. The 
data measures the status-quo or static environ and ignores the evolutionary changes to estuarines.

Inherent in scientific studies used is the presumption of man not being included as part of the environ. Therefore, any resulting actions of man would be a deviation from the natural ecology. This speaks directly to the philosohical approaches mentioned in chapter four. The scientific evidence used supports the extreme point of view regarding man and the environment. Namely, man is separate from and not to be considered a part of the environ. This radical view is single focused, especially considering man's historical interaction with the coastal zone.

\section{Insight}

In $1980 \mathrm{Dr}$. Nixon of G.S.O. wrote a paper reviewing twenty years of speculation and research on the role of salt marshes in estuarine productivity and water chemistry. In the introduction he provides some historical perspectives about John Teal. Teal's 1962 paper synthisized a variety of studies concerning the ecosystems of salt marshes. The conclusion of the paper supported a then popular belief, no longer valid, that had great appeal. Dr. Nixon warns researchers to be wary of conclusions pronounced with more weight than the data warrants.

At the end of the paper Dr. Nixon provides an insightful look at researchers perceptions and views of 
ecology and oceanography. Dr. Nixon expresses a common sentiment found in the ecological community doing research on the question of marsh-estuarine interactions. He talks in terms of the battle to preserve the marshes.

\footnotetext{
"The momentum of the developers was so great that an atmosphere of certainty and consensus was necessary for the voice of the ecologists to be heard. The essence of the argument is that, "Yes, perhaps we overstated the case a bit, but it was important to help save the marshes." (14)
}

Dr. Nixon clearly disagreed with this approach, he feels trading credibility for political advantage is a bad bargain.

"Reading the literature on marsh-estuarine
interactions convinces me that we have been
too willing to trust our own preconceptions,
and too eager to believe what other people
are saying about their data when they agree
with those preconceptions. Ecology is a
young science, and we are still about the
business of learning some of the basics." (15)

These apparently prevalent views should be taken into consideration when evaluating the SAM plan.

\section{Summary}

Collaboration with U.R.I. Coastal Resources Center and staff from DEM Coastal Resource Division further enhanced an environmental orientation by CRMC. The data used to make policy was prepared and presented by CRC Researchers with a specific orientation. The data is incomlete and consistently presents the extreme case. 


\section{CHAPTER VI}

\section{Lessons in Bureaucracy}

This chapter will integrate Part I and Part II and identify major issues that include, bureaucratic and institutional dynamics, and the government level at which local land-use decision-making should be made. The analysis to this point has determined that planning is taking place on a regional level by an appointed council having questionable authority and justification for their non-coastal concerns.

\section{Networking}

Rhode Island is a small state, that allows close professional contacts at various levels of government. This familiarity provides a network of local and state bureaucracy. State and local planning efforts during the 60's and 70's established a professional net work and a sound data base.(1) Various policies emerged from this planning effort and culminated with the landmanagement bill of 1976. The main architect for the bill was the statewide planning program (SPP). S.P.P. chief served as the point man in guiding the bill through its public hearing.(2) The bill did not have wide community support(3) but some shore region policies promulgated from the support document (Table 6-I) are in place.

The policies advocated by the S.P.P. recognize human interaction with the coastal zone and are 
TABLE $\underline{6-1}$

1975 STATEWIDE POLICIES FOR THE SHORE REGION

Policy \#1:

"DEVELOP RESOURCE MANAGEMENT PLANS" FOR THE SHORE REgION WHICH ARE "COMPATIBLE WITH THE NEEDS OF THE PEOPLE OF RHODE ISLAND, WHILE PRESERVING AND ENHANCING AS FAR AS POSSIBLE THE NATURAL QUALITIES OF THE MARINE ENVI RONMENT. "

Policy \#2:

EXAMINE PROPOSALS FOR CHANGES IN THE COASTAL REGION "IN TERMS OF THEIR ECONOMIC, RECREATIONAL, AESTHETIC AND ENVIRONMENTAL IMPORTANCE TO ALL OF THE PEOPLE OF THE STATE" IN COMMON RATHER THAN TO INDIVIDUAL COMMUNITIES OR "SMALL, SPECIAL INTEREST GROUPS."

Policy \#3:

SUPPORT "PROGRAMS TO ABATE POLLUTION" AND "EXAMINE ALL PROPOSALS FOR USE OF THE STATE'S MARINE RESOURCES IN RELATION TO THE DEGREE OF POLLUTION WHICH MAY RESULT."

Policy \#4:

"ENCOURAGE DEVELOPMENT OF BOTH SPORT AND COMMERCIAL FISHERIES BOTH INSHORE AND OFFSHORE UP TO LEVELS OF MAXIMUM SUSTAINABLE YIELD PROVIDING SUCH DEVELOPMENT DOES NOT CURTAIL OTHER MORE IMPORTANT USES."

Policy \#5:

"DEVELOP MANAGEMENT REGULATIONS FOR SAND AND GRAVEL AND MINERAL EXTRACTION WHICH WILL PERMIT EXPLOITATION ONLY IN WAYS WHICH WILL NOT PREVENT OTHER USES OR DAMAGE MARINE LIFE."

Policy \#6:

PREVENT FILLING OF COASTAL WATERS AND WETLANDS EXCEPT WHEN NECESSARY TO THE HEALTH OR WELFARE OF THE PEOPLE OF THE STATE, AND THERE IS NO OTHER ALTERNATIVE. 
Policy \#7:

PROTECT SELECTED AREAS FROM THE EFFECTS OF FLOODING AND EXTREME TIDAL ACTION; LIMIT TEE INTENSITY OF DEVELOPMENT OF UNPROTECTED AREAS.

Policy \#8:

"COOPERATE WITH LOCAL GOVERNMENTS IN ALL MATTERS OF MUTUAL INTERESTS AND . . ENCOURAGE MUNICIPALITIES TO MAKE FULL USE OF THE JURISDICTION AVAILABLE TO THEM."

Policy \#9:

EXTEND "THE JURISDICTION OF THE STATE OVER OFFSHORE WATERS TO THE MAXIMOM EXTENT POSSIBLE AND (WORK) • • CLOSELY WITH THE FEDERAL GOVERNMENT TO INSURE THAT FEDERAL AGENCIES EXERCISE THEIR AUTHORITY IN A MANNER CONSISTENT WITH THE INTEREST OF RHODE ISLAND." 
sensitive to environmental considerations. The goals of the SAM plan limit human interaction and fosters an ecosystem approach which views most human activity as separate from and detrimental to the coastal zone. CRC, DEM, and SPP are state agencies oriented towards science, the environment and planning. CRMC relied heavily on these agencies for establishing policies. Bureaucratic networks established strong lines of communication during the policy formulation stage. Compatible goals of each agency melded together eventually leading to the development of questionable SAMP land-use powers justified by tenuous scientific data. As is often the case, regulatory agencies attempt to justify their existence and sometimes overstep their bounds. (4)

The penchant of state agencies towards scientific environmental planning is understandable and a natural extension of agency policy. The practice of combining federal grants to achieve similar goals reinforced bureaucratic networking.(5) Unfortunately, the result of such networking during policy development quietly expanded CRMC in areas outside its legislative mandate and a conscious effort to establish sound planning principals on a regional basis. The argument is not the propriety of assumption of land-use powers, but rather the process used in acquiring land-use authority. 


\section{Challenges}

The correct authority for land-use decision-making is the legislative process, not bureaucratic networking and policy making. The General Assembly using the legislative process defeated the land-management bill. Pending bills in the Assembly should diligently consider other land-use tools that reorder and reprioritize basic concepts. A bill advocating environmentally based zoning was before the last session of the General Assembly.

Perception of the environment varies over time and place. The worldwide prevailing societal view of property rights, has a unique American twist. The twist is the ascendency of individual property rights. Perceived vested rights has led to the establishment of land-use planning and decision making at the local level. Most fundamental land-use determinants of community growth patterns are controlled by the local government. Such basic funtional systems are utility lines and ordinance, i.e. zoning and subdivision regulation.

Economic and locational determinants affecting land-use are important where historically mankind has been a major factor in the coastal zone. Increasing pressure for additional residential development in the coastal zone is expected to continue and can be translated into economic terms. 
Economic determinants play a significant role in land-use patterns. Historically industry, commerce, and manufacturing have located on or adjacent to coastal zones influenced by the land-water interface that provided transportation and communication networks. With the advent of modern communication and highway systems this dependency was not as critical. The same system enabling industry, commerce and manufacturing to disperse from the coast line enabled easy access to the coast by people. Coastal residential patterns are a reflection of man's interaction with the coast and his desire to be near the coast. Building permits for residential units have increased dramatically in SAMP towns.

Demand for residential units in the coastal zone creates a regional development boom. This development boom has all the facets associated with a microcosm industry: developers, speculators, realtors, general contractors, individual craftsmen, and all the other components of the building industry. This industry sells a product; namely, houses, usually expensive housing. The orientation of the development industry is to muster large amounts of money to maximize profit. These two facts produce an ominous future for SAMP. Expenses to earn greater profits are always acceptable. Industries with large amounts of capital, such as the development/building industry are willing to 
incur an upfront expense to make more money at the bottom line. Residential zoning density is one way to increase profits. Areas of discrepancy exist between SAM plan residential policies and local zoning. Eventually legal challenges may arise from the communities.

The legal foundation for land-use decision-making rests with local government. The consistency between comprehensive plans and zoning is a long established legal precedence. Discrepancies between SAMP and local zoning could be problematic. A legal standard used in determining consistency is whether the finding was quasi-judicial or legislative.(6) "When a court characterizes a land-use decision as quasi-judicial, the traditional presumption of validity accorded legislative decisions does not apply."(7) This rule means the burden of justifying the challenged decision is with the quasi-judicial body.

Land-use regulation should be at the local level with sound and comprehensive planning guidance by the state. Zoning enabling legislation by the state should be environmentally oriented. A move in this direction through legislative means is the correct process for developing and implementing environmental land-use policies.

The legality of the decision-making process is important because of the perception of property rights. 
The assignment of these constitutional rights are supercedent to CRMC implicit presumption of societal rights. Inherent societal rights are the underlying presumption of environmental issue. The operative force, contrary to environmental issues, is individual property rights and until the dilemma in perception of these rights is resolved, using legislative process, sound environmental comprehensive planning will not take place.

The perception of property rights and decision making are important when evaluating programs. SAMP affects community development. As communities grow and change, the perceptions of the residents are liable to change. Growth options will be limited and this may present problems for a regional plan like SAMP.

In the coastal communities various human activities, including residential, industrial and commercial land-use patterns, have and will continue to interact in a dynamic and ever evolving process. The process, includes land-use decision-making on the local level. The special area management plans (SAMP) have limited potential options available to a community. Control of infra-structure functional systems such as water and sewer 1 ines and road networks are the essential tool for community development planning. (8) Traditionally, permission by the state is not required for initiating such systems. The SAMP requires CRMC 
assent for sewers, waterlines and roads within the region. It is questionable if the coastal zone management act (CZMA) was meant to grant sweeping landuse control to the Coastal Resource Management Council (CRMC) .

The legislation was specific in limiting authority over land areas to that necessary to carry out effective resource management.

At issue here is can a state management council justify control of key community development tools necessary to determine future growth? The suggestion is CRMC has overstepped their jurisdictional authority by narrowly focusing their legislative mandate. Justification for controlling land-use decisions centers on groundwater pollution. Incomplete data indicates nitrogen, in the form of nitrates, are entering the salt ponds. Nitrates enter from a variety of sources. (Table 6-2) Some scientic research attributes groundwater nitrates from ISDS. Assigning percentages of nitrates leaching from a variety of sources is difficult at best. Groundwater is the most difficult of all sources to determine nitrate leaching.(9)

Nitrates within a salt pond eco-system are an essential part of the ecology. Uncertainty exists on the amount present and how quickly these amounts accumulate or dissipate. Until adequate research is conducted; the verifiable impact of nitrates leaching 


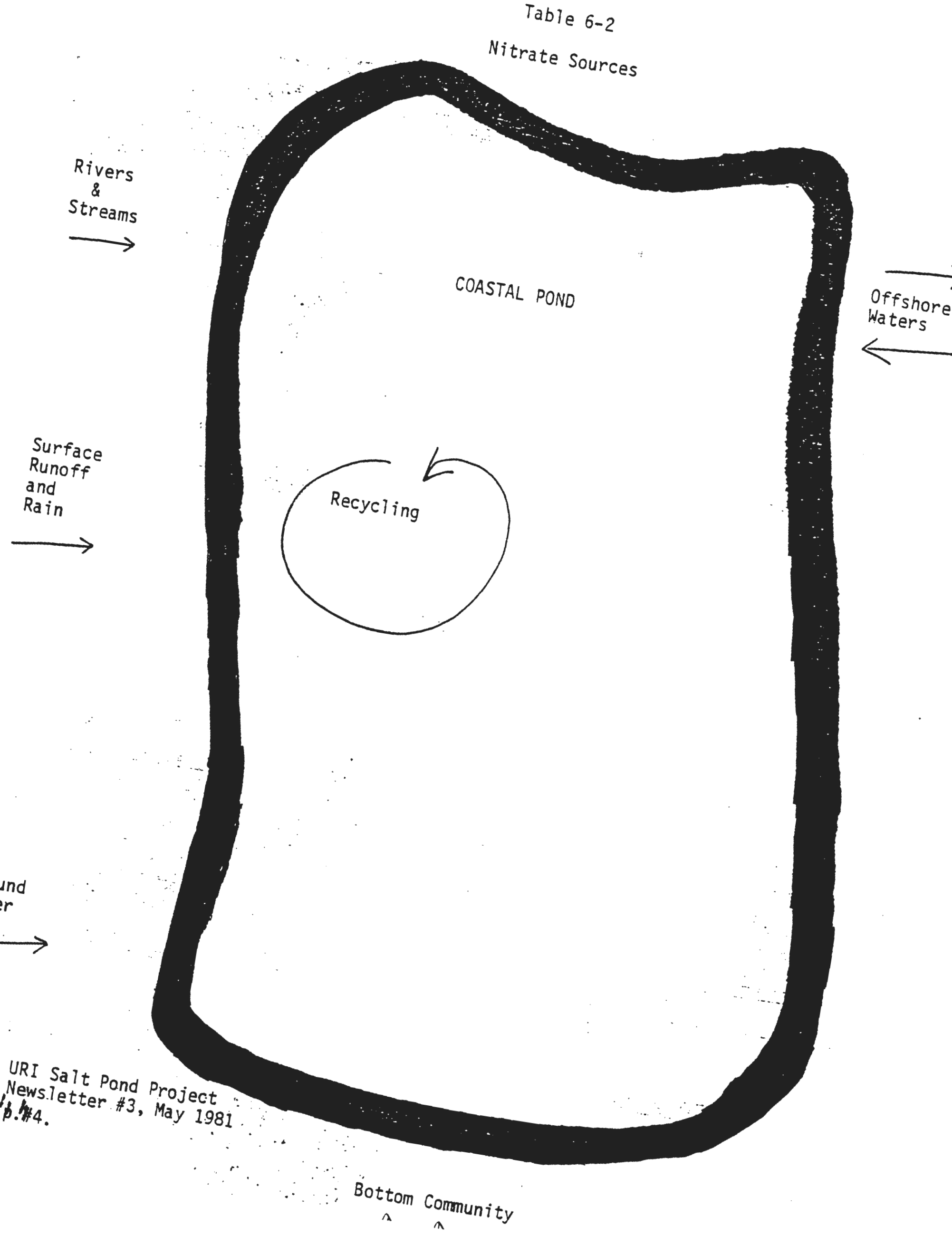


from ISDS should be viewed as a warning. Cause and effect have not been established.

SAMP's primary rational for the expansion of the landward boundary is nutrient loading and eutrophication of the salt ponds. But as demonstrated, this premise may be biased and at best incomplete. In any case, the future of SAMP is up in the air.

A 1986 report documents the trouble CRMC has enforcing its statewide program. Many people disregard policies, especially concerning follow-ups on cease and desist orders.(10) At issue is the oil and vinegar argument. What good is a plan unless it is used.

The state funded permit coordinator never materialized. Permit coordination is done on the town level. A dilemma is present for the coordinator. Whose residential rules does he follow; the towns or CRMC's? Further weakening the efficacy of SAMP.

Another institutional study by U.R.I. and CRC heralds the adaptive implementation of CRMC policy. Its quite true CRMC was adaptive. The report suggests adaptive implementation of policy by developing policies in an open forum which attempts to co-opt potential challengers. The report ends by saying, "If implementaation were automatic, then the governance of coastal ecosystems would be easy. The case of the Rhode Island Coastal Resource Management Council dramatically illustrates the opposite is true."(11) The problem can 
be viewed very differently.

The use of bureaucratic networking and biased information will hurt the credibility and implementation of SAMP. The perception of property rights and land-use regulatory control at the local level is very strong. Environmental and ecological planning use presumptive societal rights. The rights be properly identified through the legislative process because of the evolution of our systems of laws and planning concepts. The defacto practice of regional and environmental planning will not be effective. Eventually it will be altered and replaced by a more appropriate system developed by legislative not bureaucratic channels.

"Unless the initiator of a policy can galvanize the energy, attention and skills of those affected by it, thereby bringing these resources into a loosely structured bargaining arena, the effects of a policy are likely to be anything but weak and diffuse." (12)

\section{Conclusions}

The evolution of land-use controls and decisionmaking has been shaped and influenced by various catalysts. It is clear that legislative and judicial decisions have delegated to local government the authority for land use. However, it is not clear if land-use control can be assumed by a management council; nor it is clear if a local government can abrogate landuse decision-making. A 1986 Federal court decision upheld the consistency issue between regulation and the 
local comprehensive community plan.(13) This reinforces land-use decision-making at the local level.

The General Assembly never intended to grant sweeping land-use powers to the CRMC in areas outside the coastal zone. On the contrary, the Assembly quite specifically limited land-use control land-ward of the mean high-tide. The assumption and expansion of ecological management control by CRMC is based on implicit language, justified by incomplete data and assembled by a research center that has biases. The conflicting criteria in the coastal zone management act allowed the focusing of the primary ecological principals to the exclusion of operative and influcencing factors. Bureaucratic networking among state agencies, the management council and local government enabled the promulgation of land-use policies tantamount to regional land-use control. One reason for this is the disjointed and incremental nature of comprehensive planning and land use decision-making in R.I. Societal rights based on ecological considerations and perceived property rights cause a dilemma. To resolve the conflict legislative process is the proper forum.

\section{Recommendations}

The legislative process is the proper arena for solving the dilemma of societal rights and property rights. The compromise language of enabling legislation 
often taken into account variables affecting the coastal zone. The assembly should pass zoning legislation which allows local communities to control and limit excessive ecological degradation.

In the last General Assembly housebill, bill 86801, an act relating to zoning and senate bill 86-2591, an act relating to zoning would assist toward this goal. This legislation, if enacted, would provide a preferable means of controlling land-use utilizing economic and environmental considerations.

A more controversial solution would be to address the issue of individual property rights. This consitutional hallmark is ingrained to the American perception of individual property rights and would require careful study.

"Lynton Caldwell (1974) cites everal reasons for the necessity of a change in outlook toward land - a new view, one in which "privilege of use" replaced "ownership rights." He suggests that since "no man made the land, no man may possess it as his 'own." There is a strong presumption in this sort of view that the right to ownership derives from a creative input. Beyond that, there is a fundamental divergency between "the transiency of man" in this world and "the relative permanence of land." This distinction, Caldwell points out, logically leads to viewing the use of land as a privilege which carries with it a responsibility to pass it along to successive generations in essentially the condition in which it was received. He suggests the redefinition of rights to mean the right to use or occupy land in accordance with criteria established in the public interest, with the right of use or occupancy tied to defined economic and ecological capabilities." (14) 
A new realistic approach to the dynamic and multi-variables affecting land-use within the coastal zone must be found. These decisions should be made within a comprehensive framework which recognizes regional ecological consideration. This must be tempered by recognizing man's desire for working, recreating and living in the coastal zone. 


\section{FOOTNOTES}

Chapter I - Perceptions of Land Use

1 Perkins Ward, 1976, Planning and Cities, University Press, p. 14 .

2 Ibid., p. 16.

3 Ibid., p. 18.

4 Ibid., p. 12.

5 Faludi Andrens, 1973, A Reader in Planning Theory, Pergamon Press, p. 95.

6 Harris Marshall, 1953, Origins of Land Tenure System in the United States, Greenwood Press.

7 Ibid., p. 23.

8 Ibid., p. 40.

9 Ibid., p. 155.

10 Miner, Lilian, 1925, Our State Rhode Island, p. 95 .

11 Ibid., p. 210.

12 Ibid., p. 187.

13 Harris, Land Tenure, p. 3.

Chapter II $=$ Land-Use Control Rhode Island's Experience

I Rlyberg, Albert, 1979, The Lay of the Land, R.I. Historical Society.

2 Rhode Island General Assembly, February 1810, "An Act to Establish the Woonasquatucket Turnpike Corporation."

3 Ibid., October 1841, "An Act Relative to the Harbor and Public Waters of the Town of Providence."

4 Ibid., February 9, 1888, "An Act to Amend the Charter of the Narragansett Electric Lighting Company. 
5 Ibid., Chapter 679, March 23, 1888.

6 Ibid., Chapter 2069, 1921.

7 Whitten, Robert, 1923, Providence Zone Plan, p. 3 .

8 Cianciarulo v. Tarro, 1961, 168A Zd 719.

Chapter III - Comprehensive Planning in Rhode Island

I Muniak, Dennis, 1981, Class notes from U.R.I., CL 570, Plan Implementation.

\section{Part II - Introduction}

1 Lindblom, Charles, 1980, The Policy-making Process, 2nd Edition, p. 66.

2 Ibid., p. 88 .

\section{Chapter IV - Coastal Zone Management Act}

I See Appendix A.

2 Interview John Lyons, CRMC member and author of CzMA legislation, November, 1986.

3 Quinn, Thomas, 1981, R.I. Coastal Zone Management, An Evaluation, term paper.

4 R.I. Coastal Resources Management Council, January, 1981, Coastal Resources Management Program, p. 229.

5 R.I. General Law, 46-23-I.

6 Hennessey, Timothy, Robadue, Donald, November, 1986, Adaptive Implementation and Coastal Ecosystems Management, p. 12 .

$7 \quad$ Kaiser enforcement.

9 Journal Bulletin, February 24, 1981.

10 Providence Sunday Journal, October 20, 1985, P. C-12.

\section{Chapter $\underline{V}-\underline{\text { SAM }} \underline{\text { Plan }}$}


1 The 1977 Amendment Language before and after is found in Appendix A.

2 Hennessey, Timothy, Robadue, Donald, 1986, U.R.I. Coastal Resource Center, Adaptative Implementation Coastal Management, Noaa, Sea Econsystem, Grant, p. 25 .

3 R.I. General Law, 46-23.1.

4 Charlestown and South Kingston had identical reports for 18 months before the adoption of the SAM plan, this would indicate a lack of political resolve to adopt the plan at the local level.

5 Brewer, Gary, 1973, Politicians, Bureaucrats, and the Consultant, Basic Books.

6 See Appendix B for list of previous work by the SAM plan authors, Lee and Olsen.

7 Lee, Virginia, Olsen, Stephen, 1984, R.I. Salt Pond Region: A Special Area Management Program. Coastal Resources Management Council, p. 28 .

8 Ibid., p. 30 .

9 Klyberg, Lay of the Land, p. 19.

10 Lee, Virginia, 1980, An Elusive Compromise - R.I. Coastal Ponds and Their People, U.R.I. Coastal Resources Center Report \$73, p. 15.

11 Lee, Virginia, Olsen, Stephen, 1984, R.I. Salt Pond Region, p. 71 .

12 Nixon, S., Oviatt, C., 1973, Analysis of Local Variation in the standing Crop of Spartina Alterniflora, U.R.I. Marine Reprint \#7, p.108.

13 Lee, Virginia, Olsen, Stephen, 1985, Eutrophication and Management Initiatives for the Control of Nutrient Inputs to R.I. Coastal Lagoons, U.R.I. Coastal Resource Center, \#167, p. 198.

14 Nixon, Scott, 1980, Between Coastal Marshes and Coastal Waters, U.R.I. School of Oceanography Marine Reprint \#124, p. 439. 
1 Cannon, Vincent, 1976, An Analysis fo the Attitudes of Local Planning Directors, U.R.I. thesis.

2 Journal Bulletin, April 6, 1976.

3 Ibid., November 23, 1977.

4 Galloway, Thomas, 1982, The Newest Federalism, A New Framework for Coastal Issues, center for Ocean Management Studies, p. 199 .

5 Funding for the Salt Pond Project was provided by the Sea Grant Program, the Office of Coastal Zone Management, and the 208 Water Quality Program.

6 Galley, Benjamin, 1985, Zoning and Planning Law Handbook, Clark Boardmen Co., Ltd., p. 111 .

7 Netter, Edith, 1981, Land-Use Law: Issues for the Eighties, American Planning Association, p. 66 .

8 Gailey, Benjamin, 1986, Zoning and Planning Law Handbook, p. 151 .

9 U.R.I. Newsletter, Salt Pont Project, Salt Ponds $\# 2$, p. 5

10 Kaiser, David, 1986, U.R.I. Coastal Resources Center, The Role of Enforcement in Coastal Resource Management, p. 10 .

11 Hennessey, T., Robadue, D., 1986, Adaptive Implemenmtation and Coastal Ecosystem Management, p. 30 .

12 Ibid., p. 4

13 Journal Bulletin, December 18, 1986, p. 1 . The town of Johnston was ordered to issue building permits because of a lack of consistency between comprehensive planning and town regulation.

14 Chapin, F. Kaiser, E., 1979, Urban Land-Use Planning, 3 rd Edition, p. 21 . 


\section{BIBLIOGRAPHY}

Balderston, 1974, Dentrification in closed System Aquaculture. Brewer, Garry D., 1973, Politicans, Bureaucrats and the Consultant, Basic Books

Chapin, F. Kaiser, E., 1979, Urban Land-Use Planning. 3rd Edition

Fitzgerald, George, 1971, Nutrient Source for Algae and their Control. Enviromental Protection Agency.

Frankfurter Felix, Mr Justice Holmes and the supreme court, Harvard Press.

Gailey, B. 1985, Zoning and Planning Law Handbook, Boardman, Co.

Gailey, B. 1986, Zoning and Planning Law Handbook, Boardman, Co.

Galloway, T. 1982, The Newest Federalism; A New Framework for Coastal Issues, Wilson Publishing Co.

Geller, Leslie M., 1983, Strategy Zoning, Prentice Hall. Gilcrhrist John A., Griggs, Gary, The Earth and Land-Use Planning, Duxberry Press.

Hale, 1974, The Role of Benthic Communities in the Nitrogen and Phosphorus Cycles of a Estuary.

Harris, Marshall, 1953, Origins of Land Tenure systems in the United States, Greenwood Press.

Hershman, M., 1981, Coastal Management; Readings and Notes, University of Washington.

Hutchinson, 1981, An Introduction to Town and Country Planning.

Isaji, Spaulding, Stace, 1985, Tidal Exchange Between a Coastal Lagoon and offshore Waters.

Kaiser, D. 1986, The Role of Enforcement in Coastal Resource Management, Coastal Resource Center

Klyberg, Albert, 1979, The Lay of the Land, Rhode Island Historical Society. 
Lee, V. 1980, An Elusive Compromise: Rhode Island Coastal Ponds and their People., report \#73.

Lemire, Robert A, 1979, Creative land Development Bridge to the Future. Mifflin co.

Likens, G.E. 1972, Nutrients and Eutrophication, Volume 1 . Iistokin, David 1974, Land Use Controls Present Problems and Future Reform, Rutgers University.

Lockwood, 1976, Effects of Pollutants on Acquatice Organism, University Press.

Mayer, Kurt, 1953, Economic Development and Population Growth in Rhode Island. Brown University.

Miner, Lilian, 1925, Our State Rhode Island.

Netter, E. 1981, Land-Use Law: Issue for the Eighties. A.P.A. Planning Press.

Nixon, Scott W. 1980, Between Coastal Marshes and Coastal Waters \#124

Odum, William 1976, Ecological Guidelines for Tropical Coastal Development. \#42.

Olsen, Lee, 1985, Eutrophication and Management Initiatives for the Control of Nutrient inputs to Rhode Island Lagoons.

Robadue, D., Hennessey, T., 1986, A Comparison of the Governance of Narragansett and San Francisco Bays. Coastal Resources Center.

Robinson, G. Gellhorn, E. Bruff, H., 1983, The Administrative Process. West Publishing Company.

Schaffer, Bernard, 1973, The Administrative Factor. Cass Publication

Thompson, Victor, 1969, Bureaucracy and Innovation. Alabam Press

Toll, Seymour, 1969, Zoned American. Grossman Publication. Warriner, Doreen, 1969, Land Reform in Principle \& Practice. Whitter, Robert, 1923, Providence Zone Plan. 


\section{GOVERNMENT PUBLICATIONS}

Planning and Your Community, 1961

Rhode Island Development Council

Non-Urban Land - Present Use and Economic

Classification, 1962

Rhode Island Development Council

Analysis of Rhode Island Land-Use, 1965

Rhode Island Development Council

Local Planning Board Survey, 1973

Rhode Island Development Council

State Land-Use Policies and Plan, 1975

Rhode Island Statewide Planning Program

Handbook for Local Planning Boards and Commissions, 1979 Rhode Island Development Council

Rhode Island State Enabling, 1981

Rhode Island Development Council

Rhode Island Basic Economic Statistics, 1985-1986

Rhode Island Department of Economics 


\section{APPENDIX}

$\underline{A P P E N D I X} \underline{\mathrm{A}}$

The original language of the Coastal zone Management Act and the Amendment to the Act.

$\underline{A P P E N D I X} \underline{B}$

List of published works of authors of the Management PIan.

APPENDIX $\underline{\mathrm{C}}$

Chapter 3 of the Management Plan. This chapter provides the major justification for expanding land use control within the management area. 
APPENDIX A

The original language of the Coastal zone Management Act and the Amendment to the Act. 


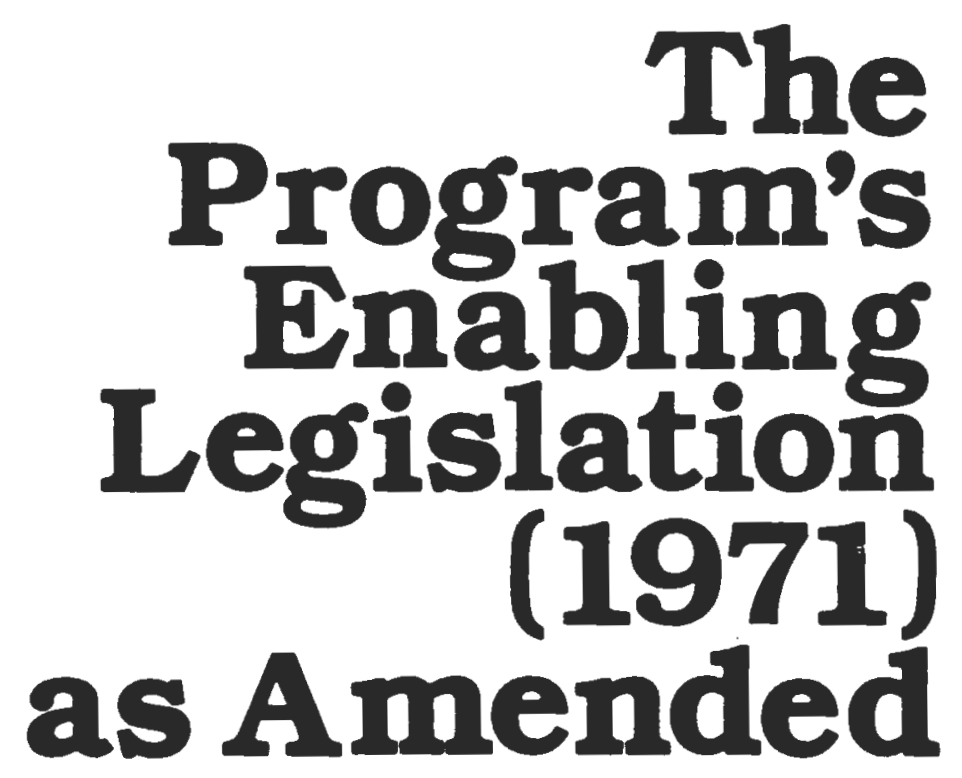




\section{Chapter 23 of the General Laws of Rhode Island}

\section{Coastal Resources Management Council}

46-23-1. Legislative Finding8. Creation. The general assembly recognizes and declares that the coastal resources of Rhode Island, a rich variety of natural. commercial. Industrial, recreational, and aesthetic assets are of Immediate and potentlal value to the present and future development of this state: that unplanned or poorly planned development of this basic natural environment has already damaged or destroyed, or has the potential of damaging or destroying. the state's coastal resources. and has restricted the most efficlent and beneficial utilization of such resources: that it shall be the policy of this state to preserve. protect. develop. and where possible. restore the coastal resources of the state for this and succeeding generations through comprehenslve and coordinated long-range planning and management designed to produce the maximum benefit for soclety from such coastal resources; and that preservation and restoration of ecological systems shall be the primary guiding principle upon which environmental alteration of coastal resources will be measured. judged. and regulated.

That effective implementation of these policies is essentlal to the social and economic well-being of the people of Rhode Island because the sea and Its adjacent lands are major sources of food and public recreation. because these resources are used by and for industry. transportation. waste disposal, and other purposes, and because the demands made on these resources are increasing in number, magnitude, and complexity; and that these policies are necessary to protect the public health. safety. and general welfare. Furthermore, that implementation of these policles is necessary in order to secure the rights of the people of Rhode Island to the use and enjoyment of the natural resources of the state with due regard for the preservation of their values. and in order to allow the general assembly to fulfill its duty to provide for the conservation of the alr. land. water. plant. animal. mineral. and other natural resources of the state. and to adopt all means necessary and proper by law to protect the natural environment of the people of the state by providing adequate resource planning for the control and regulation of the use of the natural resources of the state and for the preservation. regeneration. and restoratlon of the natural environment of the state.

That these policies can best be achleved through the creation of a coastal resources management council as the principal mechanism for management of the state's coastal resources.

46-23-2. COASTAL RESOURCES MANAGEMENT COUNCIL CREATED-APPOUNTMENT OF MEMBER8. There is hereby created the coastal resources management council. The coastal resources management council shall consist of seventeen (17) members, two (2) of whom shall be members of the house of representatives, at least one (1) of said members shall represent a coastal municipality, appointed by the speaker, two (2) of whom shall be members of the senate, each of whom shall represent a coastal municipality, appointed by the lieutenant governor, two (2) of whom shall be from the general public appointed by the speaker of the house for a term of two (2) years, two (2) of whom shall be from a coastal municipality appointed by the speaker of the house for a term of three (3) years. Four (4) appointed or elected officials of local government appointed by the governor, one (1) of whom shall be from a municipality of less than 25,000 population, appointed to serve until January 31,1972 , one (1) of whom shall be from a coastal municipality of more than twenty-five thousand $(25,000)$ population appointed to serve until January 31,1973 , one (1) of whom shall be from a coastal municipality of less than 25,000 population appointed to serve until January 31 . 1974 , and one (1) of whom shall be from a coastal community of more than 25,000 population appointed to serve until January 31,1975 , said populations are to be determined by the latest federal census; all such members shall serve until their successors are appointed and qualified; during the month of January 1972 and during the month of January thereafter, the governor shall appoint a member to succeed the member whose term will then next expire for a term of four (4) years commencing on the first day of February then next following and until his successor is named and qualified; each such municipal appointment shall cease if the appointed or elected official shall no longer hold or change the office which he held upon appointment, and further, each such appointee shall be eligible to succeed himself. Three (3) members shall be appointed by the governor from the public, with the advice and consent of the senate, one (1) of whom shall serve until January 1,1972 , one (1) of whom shall serve until January 1, 1973, and one (1) of whom shall serve until January 1, 1974, said members and their successors shall represent a coastal community. All such members shall serve until their successors are appointed and qualified; during the month of January 1972 and during the month of January thereafter the governor shall appoint, with advice and consent of senate, a member to succeed the members whose term will then next expire for a term of three (3) years commencing on the first day of February next following and until his suc. cessor is named and qualified. A member shall be eligible to succeed himself. No more than two (2) persons on said council shall be from the same community.

Appointments shall first be made by the governor then by the lieutenant governor and, then by the speaker. A vacancy other than by expiration, shall be filled in like manner as an original appointment but only for the unexpired portion of the term. The director of environmental management and the director of health shall serve ex officio.

In addition to the foregoing voting members, the council shall include a varying number of other members who shall serve in an advisory capacity without the right to vote and who shall be invited to serve by either the governor or the voting members. 
These advisory members shall represent the federal agencies such as the navy, coast guard, corps of engineers, public health service and the federal water pollution control administration and such regional agencies as the New England river basins commission and the New England regional commission and any other group or interest not otherwise represented. The council shall have authority to form committees of other advisory groups as needed from both of its own members and others.

46-23-2.1. The term of office of the appointed members shall be three ( 3 ) years only so long as the members shall remain eligible to serve on the council under the appointment authority.

The members shall be eligible to succeed themselves for one additional term only. Thereafter, no former member shall be eligible to be reappointed for a period of two (2) years.

Elected or appointed municipal officials shall hold seats on the council only so long as they remain in their elected or appointed office.

A vacancy, other than by expiration, shall be filled in the manner of the original appointment but only for the unexpired portion of the term. The appointing authority shall have the power to remove its appointee for just cause.

This section shall take effect on July 1, 1985 and shall apply prospectively to those members currently serving on the council whose terms expire thereafter.

46-23-3. QUALIFICATIONS OF MEMBERS. Each appointed member of the council, before entering upon his duties, shall take an oath to administer the duties of his office faithfully and impartially, and such oath shall be filed in the office of the secretary of state.

46-23-4. OFFICERS OF THE COUNCIL; QUORUM AND VOTE REQUIRED FOR ACTION. The governor, upon the appointment of the appointed members of the council shall select from said appointed members a chairman and vice chairman. The council shall thereupon select a secretary from among its membership or staff. The council may engage such staff as it deems necessary. A quorum shall consist of nine (9) members of said council. A majority vote of those present shall be required for action.

46-23-4.1. EXECUTIVE DIRECTOR. The council shall engage an executive director who shall be an employee of the council and who shall not be a member of the council. The executive director shall be in the unclassified service. The duties and powers of the executive director shall be determined by the council. The council shall not engage an executive director for more than three (3) years; provided, however, that the council may renew its contract with the executive director.
46-23-5. EXPENSES OF MEMBERS. The members of the council shall be paid fifty dollars $(\$ 50.00)$ per meeting as compensation and except for the chairman who shall be paid seventy-five $(\$ 75.00)$ dollars per meeting as compensation; the members and chairman shall be reimbursed for their actual expenses necessarily incurred in the performance of their duties.

Any member other than the chairman who shall act as chairman, or any member other than the chairman who shall chair any subcommittee of the council shall not receive the additional compensation paid to the chairman.

46-23-6. POWERS AND DUTIES. In order to properly manage coastal resources the council shall have the following powers and duties:

\section{A. Planning and Management.}

The primary responsibility of the council shall be the continuing planning for and management of the resources of the state's coastal region. The council shall be able to make any studies of conditions, activities, or problems of the state's coastal region needed to carry out its responsibilities.

The resources management process shall include the following basic phases:

a) Identify all of the state's coastal resources, water, submerged land, air space, finfish, shellfish, minerals, physiographic features, and so forth.

b) Evaluate these resources in terms of their quantity, quality, capability for use, and other key characteristics.

c) Determine the current and potential uses of each resource.

d) Determine the current and potential problems of each resource.

e) Formulate plans and programs for the management of each resource, identifying permitted uses, locations, protection measures, and so forth.

f) Carry out these resources management programs through implementing authority and coordination of state, federal, local, and private activities.

g) Formulation of standards where these do not exist, and reevaluation of existing standards.

An initial series of resources management activities shall be initiated through this basic process, then each phase shall continuously be recycled and used to modify the council's resources management programs and keep them current.

Planning and management programs shall be formulated in terms of the characteristics and needs of each resource or group of related resources. However, all plans and programs shall be developed around basic standards and criteria, including:

a) The need and demand for various activities and their impact upon ecological systems.

b) The degree of compatibility of various activities.

c) The capability of coastal resources to support various activities.

d) Water quality standards set by the department of health. 
e) Consideration of plans, studies, surveys, inventories, and so forth prepared by other public and private sources.

f) Consideration of contiguous land uses and transportation facilities.

g) Consistency with the state guide plan.

\section{B. Implementation.}

The council is authorized to formulate policies and plans and to adopt regulations necessary to implement its various management programs.

Any person, firm, or governmental agency proposing any development or operation within, above, or beneath the tidal water below the mean high water mark, extending out to the extent of the state's jurisdic. tion in the territorial sea shall be required to demonstrate that its proposal would not (1) conflict with any resources management plan or program; (2) make any area unsuitable for any uses or activities to which it is allocated by a resources management plan or program; or (3) significantly damage the environment of the coastal region. The council shall be authorized to approve, modify, set conditions for, or reject any such proposal.

The authority of the council over land areas (those areas above the mean high water mark) shall be limited to that necessary to carry out effective resources management programs. This shall be limited to the authority to appinve, modify, set conditions for, or reject the design, location, construction, alteration, and operation of specified activities or land uses when these are related to a water area under the agency's jurisdiction, regardless of their actual location. The council's authority over these land uses and activities shall be limited to situations in which there is a reasonable probability of conflict with a plan or program for resources management or damage to the coastal environment. These uses and activities are:

a) Power generating and desalination plants.

b) Chemical or petroleum processing, transfer, or storage.

c) Minerals extraction.

d) Shoreline protection facilities and physiograhical features and all directly associated contiguous areas which are necessary to preserve the integrity of such facility and/or features.

e) Coastal wetlands and all directly associated contiguous areas which are necessary to preserve the integrity of such wetlands. For the purpose of this chapter a coastal wetland shall mean any sale marsh bordering on the tidal waters of this state, whether or not the tidal waters reach the littoral areas through natural or artificial watercourses, and such uplands directly associated and contiguous thereto which are necessary to preserve the integrity of such marsh. Marshes shall include those areas upon which grow one (1) or more of the following: Smooth cordgrass (spartina alterniflora), salt meadow grass (spartina patens), spike grass (distichlis spicata), black rush (juncus gerar. di), saltworts (salicarnia spp.), sea lavender (limonium carolinianum), saltmarsh bulrushes (scirpus spp.) hightide bush (iva frutescens), tall reed (phragmites communis), tall cordgrass (spartina pectinata), broadleaf cattail (typha latifolia), narrowleaf cattail (typha angustifolia), spike rush (eleocharis rostellata). chairmaker's rush (scirpus americana), creeping bentgrass (agrostis palustris), sweet grass (hierochloe odorata), wild rye (elymus virginicus).

f) Sewage treatment and disposal and solid waste disposal facilities.

\section{Coordination.}

The council shall have the following coordinating powers and duties:

a) Functioning as a binding arbitrator in any matter of dispute involving both the resources of the state's coastal region and the interests of two (2) or more municipalies or state agencies.

b) Consulting and coordinating actions with local, state, regional, and federal agencies and private interests.

c) Conducting or sponsoring coastal research.

d) Advising the governor, the general assembly, and the public on coastal matters.

\section{Operations.}

The council shall be authorized to exercise the

following operating functions, which are essential to management of coastal resources:

a) Issue, modify or deny permits for any work in. above, or beneath the areas under its jurisdic. tion, including conduct of any form of aquaculture.

b) Issue, modify or deny permits for dredging, fill. ing, or any other physical alteration of coastal wetlands and all directly related contiguous areas which are necessary to preserve the integrity of such wetlands.

c) Grant licenses, permits, and easements for the use of coastal resources which are held in trust by the state for all its citizens, and impose fees for private use of such resources.

d) Determining the need for and establishing pierhead, bulkhead, and harbor lines.

e) Developing, leasing, and maintaining state piers and other state-owned property assigned to the agency by the department of environmental management, the governor, or the general assembly.

f) Investigating complaints alleging violations of state laws or riparian rights in the state's tidal waters.

\section{E. Rights-of-way.}

a) The council shall be responsible for the designation of all public rights-of-way to the tidal water areas of the state, and shall carry on a continuing discovery of appropriate public rights-of-way to the tidal water areas of the state.

b) The council shall maintain a complete file of all official documents relating to the legal status of all public rights-of-way to the tidal water areas of the state. 
c) The council shall, subject to the provisions of chapter 6 of title 37 , as amended, have the power to designate for acquisition and development by the department of environmental management land for tidal rights-of-way parking facilities and other council related purposes.

d) In conjunction therewith every state department controlling state owned land close to or adjacent to discovered rights-of-way are authorized to set out such land, or so much thereof as may be deemed necessary for public parking.

e) No such use of land for public parking shall conflict with existing or intended use of such land, and no improvement shall be undertaken by any state agency until detailed plans have been submitted to and approved by the governing body of the local municipality.

$f$ In designating rights-of-way the council shall consider the following matters in making its designation:

(1) Land evidence records;

(2) The exercise of domain over the parcel such as maintenance, construction or upkeep;

(3) The payment of taxes;

(4) The creation of a dedication;

(5) Public use;

(6) Any other public record or historical evidence such as maps, street indexes;

(7) Other evidence as set out in $\S 42 \cdot 35-10$

A determination by the council that a parcel is a right-of-way shall be decided by substantial evidence.

46-23-7. VIOLATIONS. (a) In any instances wherein there is a violation of the coastal resources management program, or a violation of regulations or decisions of the council, the council shall have the power to order the violator to cease and desist or to remedy such violation.

For the purposes of this section any development, operation, alteration or construction undertaken in any area under the council's jurisdiction as set forth in this chapter, without a valid permit of this council, shall be deemed to be a violation of a regulation or order of this council.

If the violator does not conform to the council's order then the council, through its chairman, may bring prosecution by complaint and warrant, and such prosecution shall be made in the district court of the state.

The chairman without being required to enter into any recognizance or to give surety for cost, may institute such proceedings in the name of the state. It shall be the duty of the attorney general to conduct the prosecution of all such proceedings brought by the council.

The chairman may delegate his authority to bring prosecution by complaint and warrant to such numbers of conservation officers as he may deem necessary, and said conservation officers shall not be required to enter into any personal recognizance or to give surety for cost.

The division of enforcement shall enforce the laws and regulations of the council and to this end:

(1) Conservation officers shall be empowered to issue written cease and desist orders in any instance where activitiy is being conducted which constitutes a viola. tion of the coastal resources management program or a violation of the statute, regulations or decisions of the council.

(2) Conservation officers, council members and council staff shall have authority to apply to a court of competent jurisdiction for a (warrant) to enter on private land to investigate possible violations of this chapter; provided that they have reasonable grounds to believe that a violation of the provisions of this chapter has been committed, is being committed or is about to be committed.

(b) The chairman, at the direction of the council, may obtain relief in equity or by prerogative writ whenever such relief shall be necessary for the proper performance of the council's duties hereunder. The superior court shall have the jurisdiction in equity to enforce the provisions of this chapter and any rule or regulation or order made by the council in conformity therewith. Proceedings under this section shall follow the course of equity and shall be instituted, and prosecuted in the name of the chairman and council by the attorney general, but only upon the request of the chairman, at the direction of the council.

(c) Any person in violation of an order of the council shall be guilty of a misdemeanor and upon conviction thereof shall be fined not more than three hundred dollars $(\$ 300)$ or shall be imprisoned for not exceeding three (3) months, or both so fined and imprisoned for each such offense: and each day such violation, omission, failure or refusal continues shall be deemed a separate offense.

(d) The chairman or vice chairman of the council is hereby empowered to apply to any court of competent jurisdiction for an injunction to prevent the unlawful posting or blocking of any tidal water public right of way.

46-23-8. GIFTS, GRANTS AND DONATIONS. The council is authorized to receive any gifts, grants or donations made for any of the purposes of its program, and to disburse and administer the same in accordance with the terms thereof.

46-23-9. SUBPOENA. The council is hereby authorized and empowered to summon witnesses and issue subpoenas in substantially the following form:

Sc.

To of greeting:

You are hereby required, in the name of the State of Rhode Island and Providence Plantations, to make your appearance before the commission on

in the

city of

on the day of to give

evidence of what you know relative to a matter upon investigation by the commission on 
and produce and then and there have and give the following:

Hereof fail not, as you will answer to default under the penalty of the law in that behalf made and provided.

Dated at the day of

in the year

46-23-10. COOPERATION OF DEPARTMENTS. All other departments and agencies and bodies of state government are hereby authorized and directed to cooperate with and furnish such information as the council shall require.

46-23-11. RULES AND REGULATIONS. The rules and regulations promulgated by the council shall be subject to the administrative procedures act.

\section{6-23-12. REPRESENTATION FROM COASTAL} COMMUNITIES. Upon the expiration of a term of a member appointed by the governor as an appointed or elected official of local government from a coastal municipality as set out in 46-23-2. the governor shall appoint an appointed or elected official of a coastal municlpality which at the time of the governor's appointment has no appointed or ex-officio representation on said council.

46-23-13. APPLICATION AND HEARING FEES. The council shall be authorized to establish reasonable fees for applications and hearings.

46-23-14. EXPERT TESTIMONY. The council shall be authorized to engage its own expert and outside consultants and the council shall be empowered to use such testimony in making its decisions.

46-23-15. FEDERAL AND INTERSTATE RELATIONS. The council is authorized to accept any federal grants. It is further given the power to administer land and water use regulations and to acquire fee simple and less than fee simple interests under any federal or state program. The council is authorized to coordinate and cooperate with other states in fur. therance of its purposes. The council may expend such grants and appropriations.

46-23-16. LENGTH OF PERMITS, LICENSES AND EASEMENTS. The council is authorized to grant permits, licenses, and easements for any term of years or in perpetuity.

\section{6-23-17. ANNUAL PROGRESS REPORT ON}

RIGHTS OF WAY. Within ninety (90) days after the end of each fiscal year, the council shall submit a writ. ten progress report on the development of public rights of way to the tidal water areas of the state to the state planning council, the department of environmental management, and the joint committee on the environ. ment, for review, evaluation and recommendation of the program's suitability, relevance to the recreation element of the state guide plan and impact on the natural resources of the state. The report shall also provide detailed records of expenditures and a proposed schedule of future projects.

46-23-18. ACTIVITIES PROHIBITED WITHOUT PERMISSION OF COUNCIL. (a) No person, firm or corporation shall, without a permit issued by the Coastal Resources Management Council, dredge beneath the waters or construct a marina within two thousand $(2,000)$ feet of a shellfish management area as defined by rules and regulations of the Department of Environmental Management.

(b) Any person, firm or corporation desiring to conduct either of the activities specified in Subsection (a) shall file an application with the Coastal Resources Management Council upon forms furnished by the Coastal Resources Management Council. A hearing shall be held on said application within thirty (30) days of filing and, if at the conclusion of said hearing, the Council is satisfied that there will be no adverse impact upon the environment or natural resources of the state as a result of said activities, the Coastal Resources Management Council shall grant the permit requested. The applicant shall bear the burden of proving that there will be no adverse impact upon the environment or natural resources of the state, and the Coastal Resources Management Council shall be empowered to deny such application if the applicant does not demonstrate, in addition to the other requirements of this chapter, that the activity will not adversely affect any shellfish management area as designated by the Department of Enrivonmental Management or the Marine Fisheries Council.

\section{6-23-19. SUBCOMMITTEES FOR CONTESTED CASES - APPOINTMENT OF RESIDENTS OF COASTAL COMMUNITIES AFFECTED. The} chairman of the coastal resources management council, in addition to being authorized to appoint other subcommittees, is hereby authorized to appoint subcom. mittees which shall act as hearing officers in all contested cases coming before the council. The said subcommittees shall consist of three or more members, in the chairman's discretion, provided, however, that in all contested cases one of the members shall be a resident of the coastal community affected. The city or town council of each coastal community shall, at the beginning of, its term of office, appoint a resident of that city or town to serve as an alternate member of the aforesaid subcommittees should there be no existing member of the coastal resources management council from that city or town available to serve on same. Any member of a subcommittee actively engaged in hearing a case shall continue to hear same, even though his term may have expired, until the case is concluded and a vote taken thereon. 
e. dental service.

Sec. 2. This act sibll talke effect upon passag?. Act ei:cetire,

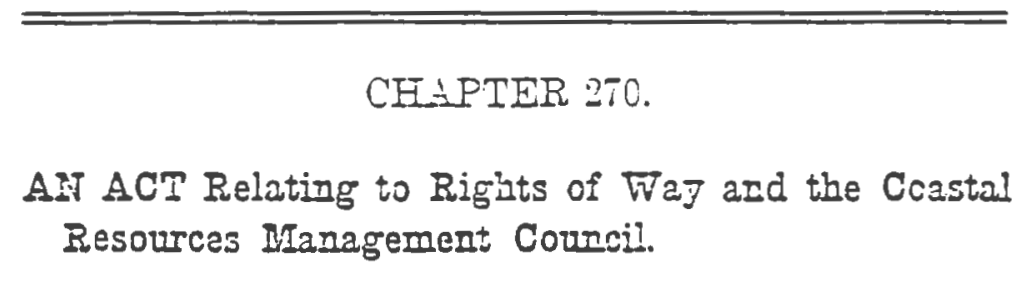

It is enacted by the Goneral Assembly as follows:

$\because-3:: 3 A$ insy $13,: 3 \pi$.

Section 1. Subsection 46-23-6 $B$ of the general laws in chapter 46-23 entitled "Coastal resources manageInent council" as amended is herevy further amended to read as follows:

"B. Implementation.-

d) Shoreline protection facilities and physio- 帒ponomeatsgraphical features, and all directly associated con- duties. tiguous areas which are necessary to preserve the in. tegrity of such facility and/or features.

(a) Coastal wetlands and all directly associated contiguous areas which are neces. sary to preserve the integrity of such wetlands. For the purpose of this chapter a costal wetland shall mean ang salt marsh bordering on the tidal waters of this state, whether or not the tidal waters reach the littoral areas through natural or artificial water courses, and such uplands directly associated and contiguous thereto which are necessary to preserve the integrity of such marsh. Marshes shall include those 


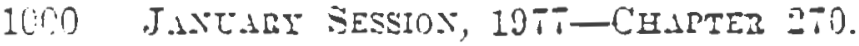

stme. areas upon which grorr one or more of the following: Smootin cordzrass (spartina altarniflora), salt meadow grass (spartina patazs), spike grass (distichlis spicata), black rush (juncus gerardi), salt wurts (saiicoinia spp. , sea lavender (limonium caroliniarum) saitmarzh bulrushes (scirpus spp.) high-ticie bush (iva frutescans), tall reed (phragmites communis), tall cordgrass (spartina pectinata), broadleaf cattail (topha Latifolia), narrowieaf cattail (typha angustifolia) spike rush (eleocharis rostellata), chairnaher's rush (scirpus amercana), creeping bentgrass (agrostis palustris), sweet grass (bierochloe odorata), wild rya (atlymus virginieus).

f) Sewage traatment and disposal and solid waste disposal facilities."

Sec. 2. Subsection 46-23-6 D of the general laws in chapter $16-23$ entitled "Coastal resourcas management council" as amended is hereby further amended to read as follows:

$6 * *$

Cosisiat

resources

corveri-

"D. Operations. - The council shall be authorized to erercise the following operating functions, which are essential to management of coastal resources:

a) Issue, modify or deny permits for any work in, above, or beneath the areas under its jurisdiction, including conduct of ang form of aquacuiture.

b) Issue, modify or deny permits for dradging, fllling, or any other physical alteration of coastal wetlands and all directly related contiguous areas which are necessary to preserte the integrity cf such wetlands. 
APPENDIX B

Iist of published works of authors of the Management Plan. 
Shelved 1D Re?.

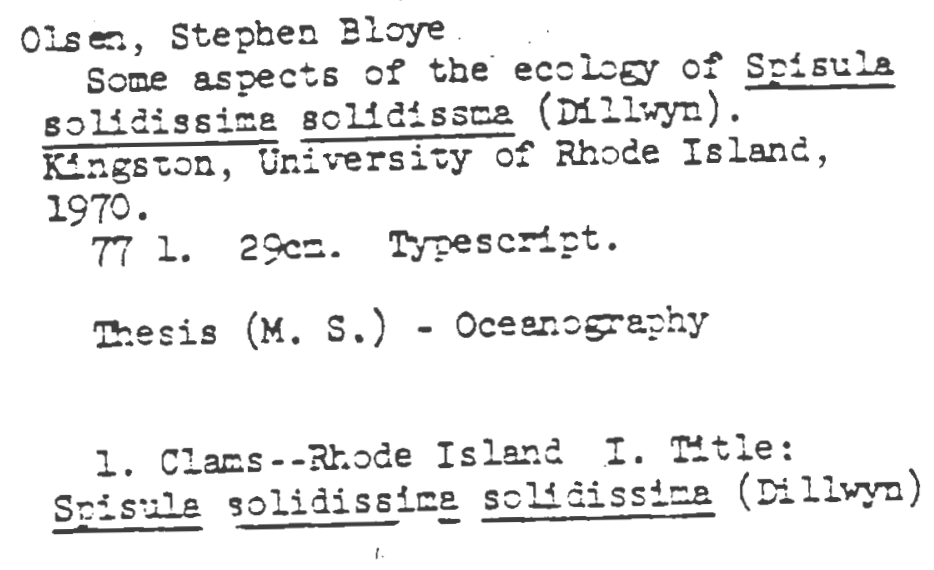

SRE9

844

Do. 19

\section{Title II. Ftlle: Besch zass (Sijies)}

01 sen, Stephen

SEㄱ?

R.45?

no. 80

Sedorick, Stephen

Comercial lshing facilitles needs in Rbode Isleri / Stepier Secjurick, Clarkson

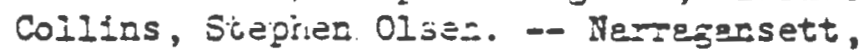
R.I.: Coastal Resources Cente:, Unirersity of Fhode IsIand, 1980.

82 p.: 1I1.; $27 \mathrm{~cm}$. --(Rhode Island. Ua1versity. Mar1ne techn1cal report; no. 80)

1. Fishiag - Rhode Island I. Colilns, Clarkson II. Olsen, Steiten III. Title IV. Series

$$
01 \text { sen, Stepinen }
$$

GC97

E36 Ecologicel consequences of ICw, sustained concentrations of petrolisum hydrocarbons in temperate estuaries / Stephen Olsen, Michsel E. Q. Pilson, Candace Oviatt, Juanita N. Gearing. -- Nerresansett: Marine Eccsystezs Research Laboratory, Graduate School of Ocenocgradby. University ni Finnta Toiand ices 
SEI9

844 no. 40
An Interpretive at las of Narragansett Bay / Step̧ez Olsea, Donald D. Robadue, Virgiafs Lee. -- Kingston: Univergity of Rhode Islend, Cosstal Resources Center, 1980. 82 p.: 111.; $28 \mathrm{~cm}$. - Rhode Island. Unitersity. Marine buliet1n; no. 40)

1. Marine ecoiosi-Narracarsett 3ay I. Olsen, Stephen II. Nobadue, Donald D. III. Lee, Vizginia $N$. Rbode Island. Unfrersity. Gradiete School of Ocesnograpiy. Coastal Resources Center V. Title: Narregarsett Bey.

$$
\text { Olsex, Stepher } 8 \text {. }
$$

SE:35

143

N4

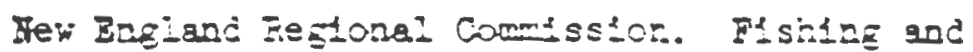
petroieus interactions... 1976-77: (Ceri 2)

charsctergtics of the two industras, potental future trends, ard an assessment of foreseesbie conflicts. -suppl. The poteatial 1mpact or coumeraial fusterdes of ground pre-enpted by petroley-reisted Btructures on Weorges Bank.

$$
\text { (tracings over) }
$$

$$
\text { Oisen, Stephen } 9 .
$$

SES

$A 43$

N4

New Engiend Regionel Comission.

Fishing and petroleud frteractions on Georzes Bank. -- :30ston;:- Hew England Regional Comission :2976-77,

2v. plus map suppl. : 111. ; -v.1, suppl. $31446 \mathrm{~cm}$. -v.2.27 cm. -- (Ener3y program techalcal reports; $76-3,77-1)$

Report prepared by Untverg1ty of Rhode Is iand Coastal Fesources Center.

Contents: - V.I. Areas of particuiar interest to the incustries. $-v, 2$. The

$$
\text { (Cont. next card) }
$$

olsan, Staphen

SB 19

8465

no. 167
Lee, Virginla Eutrophication and panazesent initiatives for the control of outrient 10puts to Rhode Island coastal lazoons Tirginia Lee. Stephen Clsea. Narragaset, $R$. I. : Coastal Resources Canter, Daiversity of Rbode Island, 1985. $[2] p:=12 l:: 26 \mathrm{~cm}:-$ (Onirersity of khode Island arlne 
Olsen, Stephen $\mathrm{B}$.

Recompendad peesurea to malatalo and protect the qualities of South

riacstorn's galt pond reaion/Prepered Ior the South Kingstorn Planning Board

by Stephen OLseo, Firginia Lee and

Clarkson Collias. - Nerragangett :

Coastal pesources canter, opI Graduate

School of Oceanoeraphy, 1982 . 37 leaves: 1 ll : : $28 \mathrm{~cm}$

npartialis runced by NOAA OfIIce of

Sea Grant, NA 81 AA-D-0073..." 1. Iidanarsh ocology--Rrode Island

2. Ponds--Rhode Igland I. Lee.

Virginia II. Colilis. ciarkson

III. dolversity of Rhode Ialand.

Coastal Resou rees Ceoter IP. TItle V. Iitle: Sou th Iisestora'b salt pond region.

11 KAR $86 \quad 13279822$ RINTdr.

Ciser, Stepinen 3 .

SHI9

BLE?

no. 55

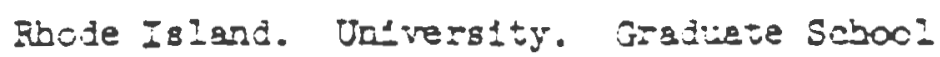
of Uceanoeraphy. Cosstal Rescuraes Cenier.

The redereiopuent o? Quorset/Datactille: an enifronmental assessuent / Frepared for tije Rhode Isiand Depertaent of Economic Developwer: by the Coastal Resources Center, Graduate School of Oceanograpir;; Unlverstty of Rhode Islend. --g Kingeton?: Unirersity of Rhode Isind, 1977.

200 p. : 111. : $22 \times 28 \mathrm{cr} .--$ (Bhode Is lend. Unfverstty. Narine techalesi repor; no. 55)

$$
\text { cont'd or next card }
$$

Olsen, Stepien B.

SHI9

R4E7

20. 55
Rhode Island. Untversity. Graduate School of Dceanogisphy. Coastai Resources Center. (Card 2) Stephen OIsen, Coordizator, Coastai Resources Ceater; Luane Ze1tlin-Male, Project Coordinator.

1. Bavironmental 1mpact statements I. Olsen, Stephea B. II. ZeftIIn-Hale, Iivne III. Title IV. Serfes
BT 393

E5

045

1985
Olsen, Stepien B.

anode Islana's salt pond region: a Special area maragement plan. Ninieret to Point Judith Poads: adopted November 27, 1984 / prepared for the Coastal iesources Managerent Council: by Stephen Olsan and Virginia Lee. Providence, II : Tbe council, $198 \overline{0}$. "xil, $1 \frac{1}{3} 35^{2}:$ : ill., maps: 28 ca.

Bibliography: p. 105-113. 1. Coastal zone mazazemant--

Environmental aspects--Fbode Island-- 
The siote of Rhoce Igland colisto

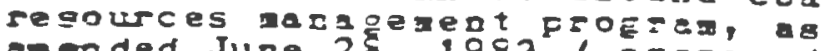
the Coagtal Resources yanagenent Council by stephea clsea and Geor Searej. - Pravidence, R.I. (60 Dav Proridence 02909) : Ihe council, [ 1 or 1994

127 p.: 112. (gone col.); 28

$\operatorname{lop}^{\text {up }} 2$

1. Coastal zane management--ihod Igland. I, Seaver, Georze L. II. Caastal Resources yaragenedt Council (R.I.) III. Iitle

10 DEC $95 \quad 11970193$ EINNAC 84-62

20424.35

Ris

078

OIsee, Steptes

1979

A sinery acd preli-inary eveluation of date peralniag to the water queity of upper SeTogarsett Ely / by Stepier OIsez and $\nabla$ inginia jee. -- Kingston: University of Rboie Isiard, Coastal Resources Center, 1979.

189 F.: 111.; $28 \mathrm{cz}$.

1. Wete=-?ollution-Narragarsett lay 2. Wate: quality-ris-garsett Bay I. Lee, Virginda II. R.I. Uriversity Gradiate School of Ocsanograpy. Coestal Resources Cente: III. Titie

ST응

R467

no. 4

Seg

Grant

RTV $T$ $73-\infty 1$
Olsez, Stepier B Sivoie Island's barrier beaches, by Stepie= B. Olser and Meicilo J. Grant. Kl-astor, University of hhode Island, Coaste? Resources Center 51973,

2 จ. 1IIus. $28 \mathrm{~m}$. Thode Island. University. Marine sechnical report no.4) Contents: v.l. il report on a racagemen probiea and an eve:untion of options. -v.2 Repors and recomendations at the communi levei.

$$
\text { I. Mtile. }
$$
jt. 245 .
II. Grant, Maicolm J (Series)

BT392

04 Olsen, Stezten

2982

Recornonded measures to rafutain and prote the qualities of Charlestown's salt pond region. Fepared ior the Ciariestewn Planring Board. / Stephen Oisen, Virginia Lee, and Clarkson Colifins. - Narragansett: Coastal Fesources Canter, URI Graduste School of Ocesnography, 2982.

1 จ. (various pasings): 111.; $28 \mathrm{~cm}$. 
Stelized in Ref.

Lee, $V i=g i n i s$

Net nitzogen riu between tie exergent warsb and tidal vaters / by Virgiais lee. - Kingstor: Univesity of Rhode Isisus, 1979.

67 1.: 111.; 29 ㄷ‥

Thesis (M.S.)-Nenogreghy.

1. Merstes, Tide-Fhode Island

2. Estliarine ecolos .3. Kitroete cyile

I. Titls

Lee, Virginia

ET392

O4 Oisez, Stepken

1982 Recomerded messures te =aintei= sad protest the qualtiles o: Chariestewn's salt pord region. Prepared for the Cearlestowr Pianing Board. / Stephen Oisen, Virgtnia Iee, and Clarkson Coli1rs. -- Sisregensett: Cosstal Resources Center, URI Greinate SchooI of Ocesoography, 1982.

1 จ. (various pegings): 112.; $28 \mathrm{cr}$.

1. Reglonal planning-Rbode Island-Chariestown

2. Coastal zone maragener:-Rbode IslendCoariestown I. Lee, Virginia II. Coll1as, Clart- son III. Mftie

\section{Lee, Virginia}

QB 541.5

524

05

1982

\section{Olsen, Stephen B.}

Reconended measures to malntain and protect the qualities of South

Kingstorn'g salt pond region/Prepared for the South Iingstorn Planning Board by Stephen olsen, Pireinia lee and clarkson Collins: - Narragarsett : Coastal Resources center. URI Graduate School of Oceanography, 1982 . 37 leares: 1 ll: : $28 \mathrm{ca}$. "Partially runded by NOAA OPtice of Sea Grant, NA 81 AA-D-0073..."

11 YAR S6 13279822 RINNdC Lee, Virginia.

HT393

R5

045

1385

Olsen, Stephen B. Zhode Island's salt pond region: a Special area managaent plan, Ninigret to Point Juditb Ponds: adopted November 27, $1384 /$ prepared for the Coastal Resources yanaegent Council: Providence, EI: The Council, 1985 . "Jui, 113p:": ill., maps": $28 \mathrm{~cm}$. bibliography: 


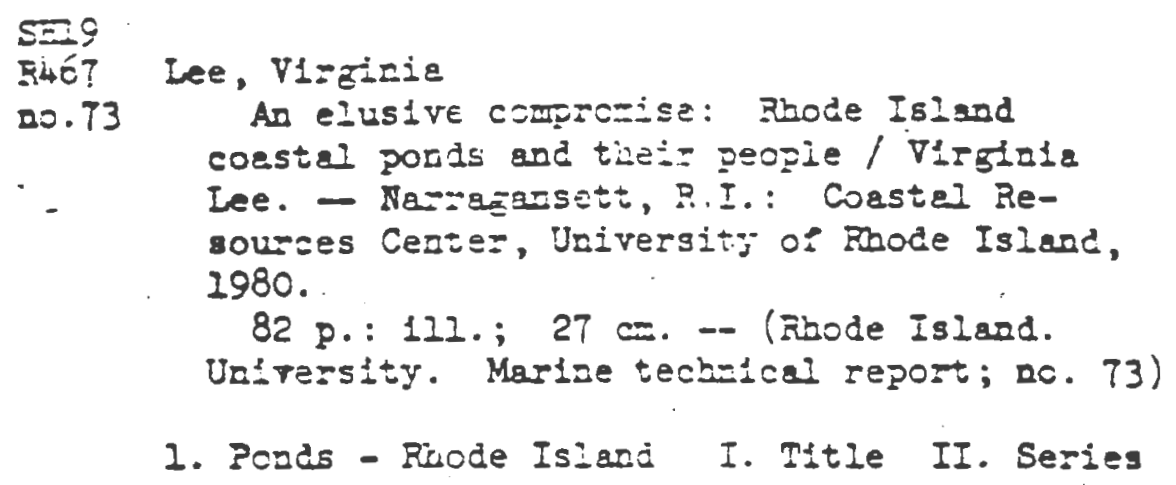

SE 15

Lae, Vireinto Eutropbicetion ond magogenent in $1+1$ atives for the control of putripat inpits to Fnode Island coastal lagoons f Pirginia Lee, Stephen Olsen. Warrgeasett, E. I. : Coostal kesourcas Center, Dnivergity of Ehode Island, 1885

[12]p.: 112 . : $26 \mathrm{cs}$. -

(Oniversity of Rhode Island arine reprint; 167.) Reprinted from Estuaries $8(2 E)$ : $191-202,1985$. NOAA/Sea Grant.

I. Olsen, Stepted II. Iitle
III. Series

$$
\begin{aligned}
& 03 \text { DEC } 85 \quad 12863873 \text { EINAdC } \\
& \text { Lee, Virginia }
\end{aligned}
$$

SE:9

RhL Ac interpretive atlas of Narrasansett Bay / ac.bo Stepbez Olsea, Donald D. Robeque, Virginia Lee. -- Kingston: University of Rhode Island, Cosstal Resources Center, 1980. 82 p.: 111.; $28 \mathrm{~cm}$. -(Rhode Isiand. Unirersity. Marine bulietL; no. 40)

1. Marine ecoiogr-Marragersett Bar I. Olsen, Stephen II. Robadue, Doneld D. III. Lee, Vifginia IV. Rbode Island. Uniressity. Graduete School of Oceanography. Coastal Resources Center

V. Title: Narreginsett Bey.

$$
\text { Lee, Virginia }
$$

$\operatorname{Toin} 24.35$

R4

078

Olsen, Stepten

1979

A sumary and prelimizary eveluation of data jertalniag to the rater quality of upper Marragarsett Bay / by Stepien Olsea and Virgfata Lee. - Klaggton: Unfrersity of Rhode Island, Coestal Resources Center, 1979 .

189 p.: 111.: $28 \mathrm{~cm}$. 
APPENDIX C

Chapter 3 of the Management Plan. This chapter provides the major justification for expanding land use control within the management area. 


\subsection{Threats to Water Quality}

A. The major water pollution problems in the region are directly related to the density and distribution of development within the watersheds of the salt ponds. Since the watersheds, as mapped in Figure 3-1, are with minor exceptions zoned for residential development, bacterial contamination and mutrient enrichment are the primary threats to water quality. As development proceeds, these pollutants w1ll increasingly threaten the quality of the salt ponds and the groundwater, whlch is the predominant source of fresh water to the ponds and sole source of the region's drinking water supply.

B. There are other potential sources of pollution that have not been examined in the salt pond region. These include such toxic compounds as gasoline and fuel oil that may be leaking from underground storage tanks, leachate from landf1lls, septic tank cleaners, herbicides and pesticides. As the region becomes more developed, stormwater runoff from roads and parking lots will become an increasingly important source of a variety of contaminants.

\subsection{Bacterial Contamination}

\section{A. Definition and Extent of the Problem}

1. In accordance with national guidelines, bacterial contamination is assessed by state health officials according to the concentrations of coliform bacteria in the water. Since 1970 state health offictals have used the concentration of fecal coliform bacteria as the indicator of sewage contamination when determining whether water is safe for drinking, shellfish harvesting and/or swiming. Since the variation among samples taken from coastal waters is frequently high, the Department of Environmental Management closes areas to shellfishing only when coliform levels consistently exceed the limits listed in Table 3-1.1

TABLE 3.1. State of Rhode Island Water Quality Standards

H1ghest Acceptable Bacteria Concentration (MPN/100 ml)

Use Total Coliforms Fecal Coliforms

Drinking Water

0

Shellfishing (salt water)

70

15

Water Contact Recreation

700

50

(salt water) 
2. Until recently, bacterial contamination sufficient to require the exclusion of shellfishing in the salt ponds was limited to northern portions of Point Judith Pond. Construction of a sewage treatment plant and sewering the town of Wakefleld greatly reduced bacterial contamination in this pond so that in 1983 the size of the closed area was reduced by approximately 60 percent. By 1980, however, bacterial contamination was a developing problem in four other salt ponds (see Figure 3-2). According to a year-long survey by the Department of Health and Nixon et al., the concentrations of fecal colfforms during the summer of 1980 consistently exceeded the shellfishing standard not only in upper Point Judith, but also in Cards and Green Hill Ponds and portions of Potter Pond. 2 The safety limits for water contact recreation were exceeded during the summer in Cards, Green Hill, Upper Point Judith and portions of Green Hill.2 Data collected by the Department of Environmental Management in Green H1ll Pond in 1982 and 1983 confirmed the high levels of bacterial contamination durfing the sumrer and fall in that pond. 3

3. Bacterial contamination is also polluting groundwater underneath the older, more densely developed communities within the watersheds. The high denstty of development and Incidence of polluted wells 1 in the communities of Matumuck and Green Hill made $1 t$ necessary for South Kingstown to bulld the South Shore Water Supply System $1 \mathrm{n}$ the 1970s. Surveys of well water $1 \mathrm{n}$ the communities between Green $\mathrm{H} 11 \mathrm{l}$ and Ninigret Ponds indicate that bacterial contamination of drinking water may also be an increasing problem here. Accordfing to Rhode Island Department of Health surveys of 163 wells. In this area between 1966 and 1972, 30 percent were judged not safe as potable water supplies due to bacterlal contamlnation. 4 By 1980 , a survey in the same area by Rhode Island Programs for the Enviroment found that 50 percent of the 19 randomly selected wells were contaminated with colfform bacteria. 5

\section{B. Sources of Contamination}

1. A number of studies 1 n suburban coastal communties suggests that the principal sources of fecal colfforms to groundwater and surface waters may include leachate from falled septlc systems, direct discharges of 1 mproperly treated sewage, fecal material from pets and l1vestock carried by runoff, leaking sewers, and sanitary landfills.6,7,8,9 In the salt pond region, failing and substandard ISDS and contaminated runoff are probably the most Important sources of bacterial contamination. 10 Trustom Pond Refuge is the only pond where dense flocks of waterfowl, are likely to be the major source of bacterial contamination. However, this pond is a National Wildlife Refuge, where boating, swimming and shellfishing are prohibited.

2. In the sait pond region, individual inground sewage disposal systems (ISDS) are the principal means of treatment and disposal of domest1c waste. In 1981 there were 5,502 ISDS in the water- 


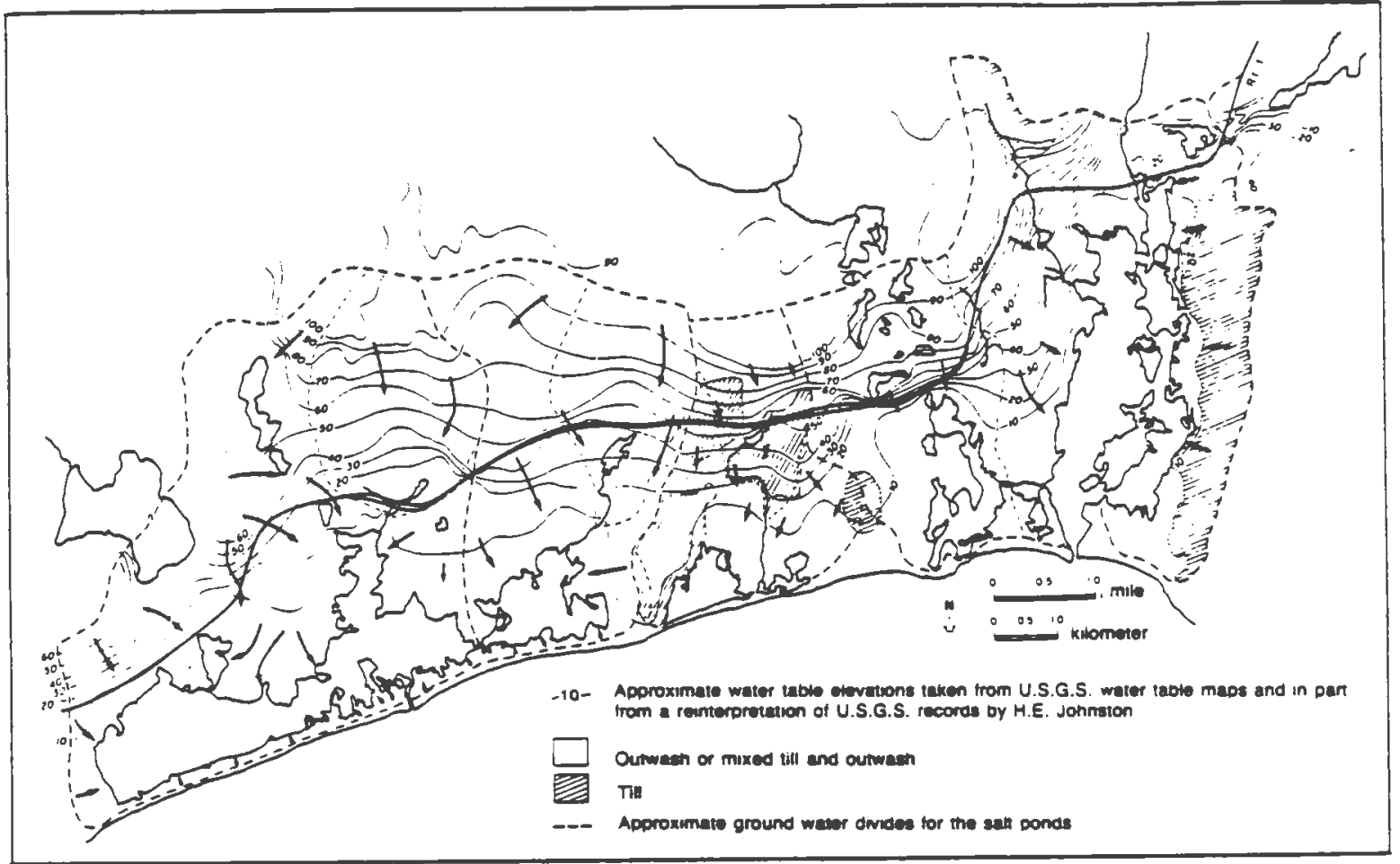

Figure 3-1. Watershed boundarles for the salt pond region. The arrows indicate approximate direction of groundwater flow. Data complled from U.S.G.S. records by John Grace, 1981.

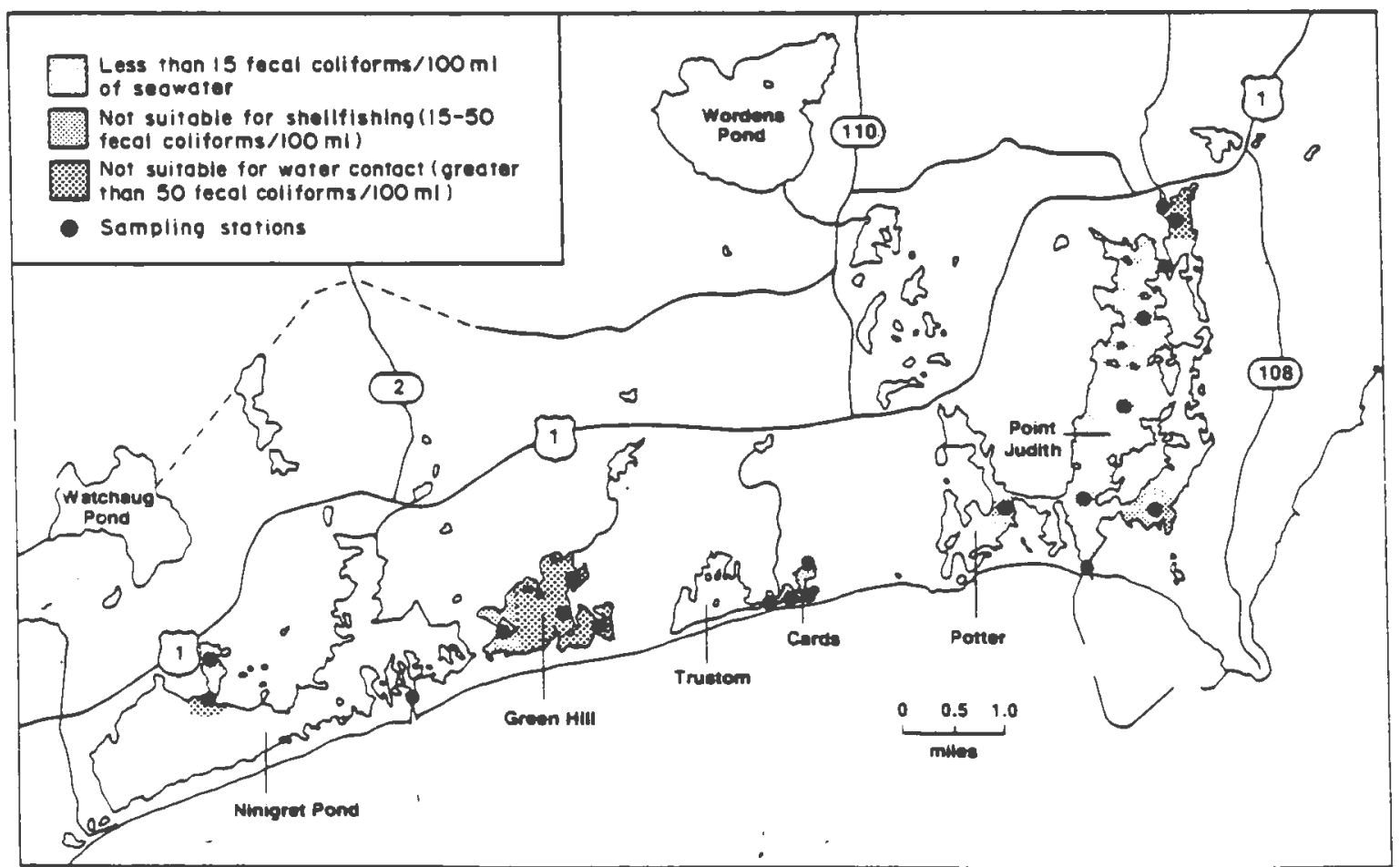

Figure 3-2. Median fecal coliform bacterla concentrations in the salt ponds 1980-1981, June through October. Adapted from Nixon et al., 1982 . 
sheds of the salt ponds. 11 Most of the ISDS in the region predate the adoption of state standards for the design and construction of modern septic systems. 6 Before state standards were adopted in 1969, domestic wastes were discharged in a variety of ways ranging from makeshift systems to dry wells and cesspools. At present a state-approved ISDS consists of a septic tank and a gravel-filled leaching bed designed and sited in accordance with strict engineering standards.

\begin{tabular}{lc} 
Watershed & \% Houses (1980) Built Before 1969 \\
\cline { 2 - 2 } Pt. Judith and Potter & 86 \\
Cards and Trustom & 75 \\
Ninigret and Green H111 & 54
\end{tabular}

According to the 1970 Rhode Island census, 49 percent of the houses in the Charlestown salt pond region, 29 percent of the houses 1 n South Kingstown's salt pond region and 42 percent of the houses in the Narragansett salt pond region were seasonal unts designed for summertime use only. These houses are being rapidly converted for year-round occupancy, usually without Improvements to the sewage disposal system. By 1980 the number of seasonal dwellings in the region decreased by a third.11

3. Properly designed and sited septic systems effectively treat the bacteria in domestic waste. However, their useful life is ilmited, estimated by various studies to average 20 to 50 years.12 A septic system is judged to have falled when the wastewaters are no longer absorbed below ground level, the system clogs up, and wastewaters pool on the ground surface. Septic systems fall as the capacity of the soll to adsorb effluent diminishes over time, when organics and silt accumulated from years of effluent flow clog the soll pores and the leaching field can no longer filter the wastewaters. According to national studies, it is not umusual for septic systems to fall before their designed lifetime due to lack of malntenance, unsultable soll characteristics, seasonally high water table, or improperly designed leachfields.13 Fecal coliforms from ISDS effluents have been documented to move over 200 feet 1 water-saturated solls or coarse solls with high permeability. 14 Dye studies have shown that septic systems in densely developed surburban areas can be the principal source of bacterial contamination to nearby coastal waters through both surface and subsurface flows. 15

4. Stormwater runoff is also a significant source of bacterial contamination to the salt ponds, as is evident from the high concentrations of coliforms in the waters adjacent to developed areas after heavy rainstorms. 2 It has been documented that runoff becomes an increasingly important source of bacterial contamination as lands adjacent to coastal waters become densely developed. 9 Road runoff is also a source of several other pollutants including heavy metals, petroleum hydrocarbons, nutrients and sediment. 16 
5. Boats and marinas are seasonal sources of bacterial contamination. During the 1980-81 survey, coliform concentrations were elevated above safe shellfishing standards during the summer in upper Polat Judith Pond and Smg Harbor.2

\subsection{Nutrient Loading and Eutrophication}

A. Defintion and Extent of the Problem

1. Eutrophication occurs when mutrients, primarily nitrogen and phosphorus, trigger excessive plant growth. This growth can be aesthetically displeasing and a threat to environmental quality. Eutrophic conditions can cause oxygen levels to fall below 4 parts per milion, the minimum required by most fish and shellfish to survive.17 Eventually, fish and shellfish populations decline, waters become weed-choked and murky, the bottom becomes coated with black organic sediments, and anoxic conditions occur that frequently lead to the generation of toxic levels of hydrogen sulfide.

2. It is generally considered that in marine ecosystems nitrogen is the essential nutrient. which limits plant growth, while in freshwater ecosystems phosphorus plays the controlling role.18,19 As estuarine systems, the salt ponds are characterized by a range of habitats, from wearly marine close to the breachways to nearly fresh where stream flow or groundwater enters the ponds. Thus, nitrogen is limiting growth throughout most of the more saline Ninigret and Point Judith Ponds, while both phosphorus and nitrogen limit growth in Green Hill, Potters, Trustom and Cards. 20 In freshwater systems and deep estuaries where free-floating microscopic plants (phytoplankton) dominate, eutrophication is characterized by high nutrient concentrations in the water and a high phytoplankton biomass. It appears that in high salinity shallow estuaries like the salt ponds, however, where seagrasses and large algae dominate, these large plants remove nutrients so rapidly that nutrient concentrations in the water remain low. Fertilization experiments in Ninigret Pond confirm that sustained additions of inorganic nitrogen cause massive blooms of green nuisance algae, particularly of Ulva and Enteromorpha (Figure 3-3). Although less dramatic, growth of eelgrass was also stimulated by nitrogen additions. 21

3. Symptoms of eutrophication are locally prevalent in the ponds during the summer months. Large rafts of algae entangle the grassbeds in Ninigret Pond, portions of Point Judith Pond, and Seaweed and Segar Coves of Potter Pond. 22 Dense growth of the green alga Enteromorpha occurs around the edges of the ponds, particularly on the southern flats of Green Hill and Potter Ponds. 22 Thick growths of the red alga Gracilaria cover parts of the bottom of Ninigret and Point Judith Ponds.22 During the summer Cards Pond is choked with extensive beds of Potomogeton, and the low salinity water of Trustom Pond is murky because of high concentrations of phytoplankton. As temperatures rise in July and August and the algae decay, the amount of dissolved oxygen in the water declines, 


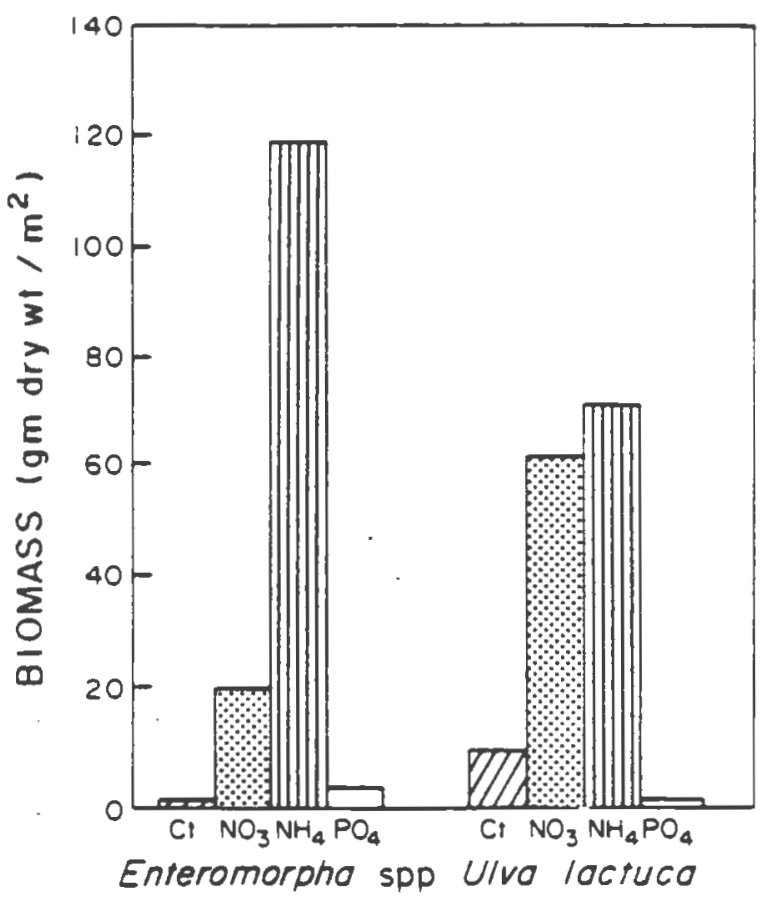

Figure 3-3. Response of green algae in Ninigret Pond to nutrient enrichment during the summer of 1980 . Note the dramatle growth response to nitrogen additions compared to phosphorus. Data from Harlin and Thorne-Miller, 1981.

creating anoxic conditions in localized areas, particularly in the more restricted coves. Abundant plant growth decomposes on the bottom and changes the character of the sediment. Clean bottom sands and gravels are covered with organic mud, which decreases the suitability of the habitat for desirable shellfish and finfish. In the upper coves of Point Judith and Potter Ponds, for example, organic content of bottom sediments exceeds 8 percent, a level which is considered typical of eutrophic water bodies (see Chapter Four, Figure 4-3). 23

4. Extensive sampling of the groundwater reveals that the concentration of total nitrogen beneath densely developed areas is elevated 100 times above the background levels found in areas unaffected by man 24 (Figure 3-4). Nitrogen in the groundwater of the salt pond region is predominantly in the form of nitrate. $24 \mathrm{~A}$ high level of nitrate in the groundwater is a public health problem, since groundwater is the sole source of drinking water for public water supplies and private wells in the region. The federal health limit for nitrate concentration in drinking water is 10 parts per million by weight $(10 \mathrm{ppm}) .25$ Higher concentrations are considered a public health hazard and can cause infant cyanosis, a condition where nitrogen rather than oxygen is transported by the blood and the child suffers oxygen starvation which, in severe 


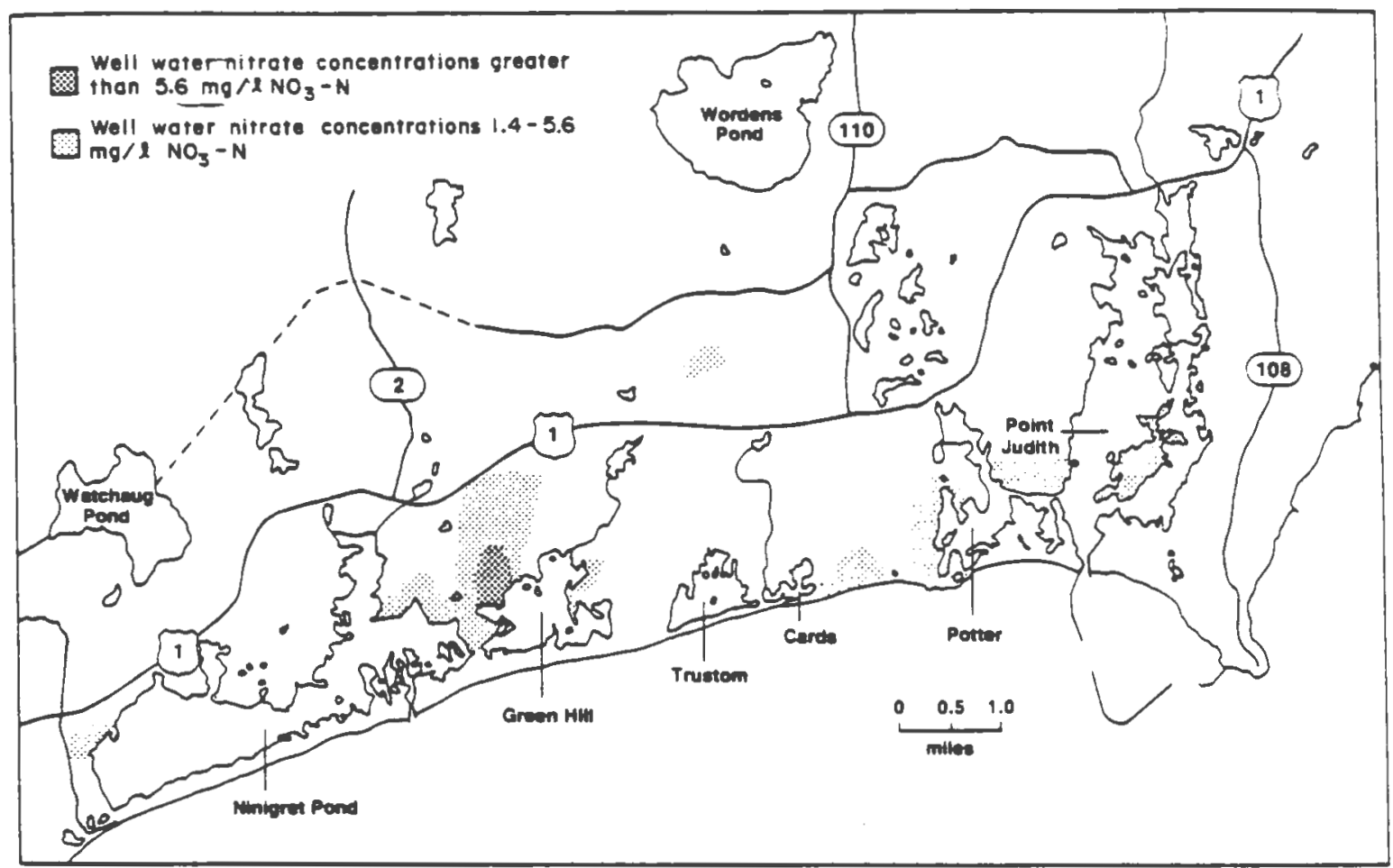

Figure 3-4. Distribution of elevated nitrate concentrations in the groundwater of the salt pond region. Concentrations are in milligrams of nitrate nitrogen per liter ( $p p m$ ) and are mapped from data taken seasonally of groundwater from over 200 residentfal wells in the region. From Nixon et al., 1982. (See Flgure 3-6).

TABLE 3-2. Preliminary Estimates of Inorganic Nitrogen Inputs to the Salt Ponds (lbs. : $/$ yr.) (from field measurements by Nixon et al. 1982)

\begin{tabular}{|c|c|c|c|c|c|c|}
\hline Source & $\begin{array}{l}\text { Nin1gret } \\
\text { Pond }\end{array}$ & $\begin{array}{l}\text { Green H111 } \\
\text { Pond }\end{array}$ & $\begin{array}{l}\text { Irustom } \\
\text { Pond }\end{array}$ & $\begin{array}{l}\text { Cards } \\
\text { Pond }\end{array}$ & $\begin{array}{l}\text { Potcer } \\
\text { Pond }\end{array}$ & $\begin{array}{l}\text { Pt. Judith! } \\
\text { Pond }\end{array}$ \\
\hline Groundwater & 66,920 & 37,080 & 9.260 & 13,910 & 24.317 & 59,830 \\
\hline $\begin{array}{l}\text { Precipitation on } \\
\text { ponds surface }\end{array}$ & 7,400 & 1.860 & 680 & 180 & 2,420 & 6,790 \\
\hline Storm runoff & 500 & 230 & 70 & 150 & 140 & 810 \\
\hline Streams & 2,800 & 2,460 & 0 & 570 & 0 & 16,000 \\
\hline Block Isl and Sound & 6.000 & 3.000 & 0 & $\underline{0}$ & in prep. & in prep. \\
\hline TOTAL & 83,620 & 42.540 & 10,010 & 14,820 & 25,880 & 83,440 \\
\hline
\end{tabular}


cases, can lead to brain damage or death. In some areas around the ponds, attrate levels in the groundwater approach, and 1 in a few cases exceed, the national health standard. 24

B. Sources of Nutrient Enrichment

1. Quantification of the principal sources of total inorganic nitrogen to each of the salt ponds demonstrates that groundwater is the dominant pathway by which nitrogen enters the ponds (Table $3.2)$.

2. It is evident from extensive research on Long Island and elsewhere that ISDS and lawn and garden fertilizers are predominant sources of ndtrogen to the groundwater in residential areas.9,26,27,28 For a three-person household on one acre of land with 15,050 square feet of lawn and/or garden, the ISDS is the largest source of nitrogen to the groundwater (Figure 3-5). The EPA estimates that the average person produces wastes contalning 10 pounds of nitrogen and 3 pounds of phosphate each year. 25 when domestic sewage is discharged to an ISDS, phosphate is readily adsorbed onto soll particles, but approxlmately half the nitrogen leaves the leaching field in the highly soluble nitrate form and enters the underlying groundwater.29,30 The gravelly glaclal outwash solls that predominate in the salt pond region are particularly susceptible to this process. Nitrateenriched groundwater then flows toward the ponds through glactal outwash solis at speeds ranglng from one to four feet per day. 3 I

3. Technologies are belng developed that convert the dissolved nitrogen in sewage to nitrogen gas and release it to the atmosphere, a process known as denterification. One promising design for dentifification units that are capable of removing 80 percent of the nitrogen and aearly 100 percent of the phosphate is being tested in Charlestown. 30 Wetlands are natural denttrifers and can play an important role in reducing the amount of aftrogen transported by groundwater into the salt ponds.

4. An analysis of land use practices in the salt pond region, combined with the predicted loadings taken from the scientific i1terature for varlous land use categorles, suggests that ISDS effluents and lawn fertilizer are major sources of nitrogen loading to the groundwater. 20 These calculations (see Table 3-3) indicate that for Point Judith and Potter Ponds and Ninigret and Green H111 Ponds, residentlal development accounts for 80 percent and 75 percent of the annual nitrogen inputs, respectively. Agriculture dominates within the watersheds of Trustom and Cards Pond and is likely to be responsible for most of the nitrogen loading to these two ponds. 
'jable 3-3. Sources of Inorganic Nitrogen to Groundwater Predicted from titerature Values for Loading and Land Use and Housing Units

in the Region in 1981. Loading untes are pounds of nitrogen per year.

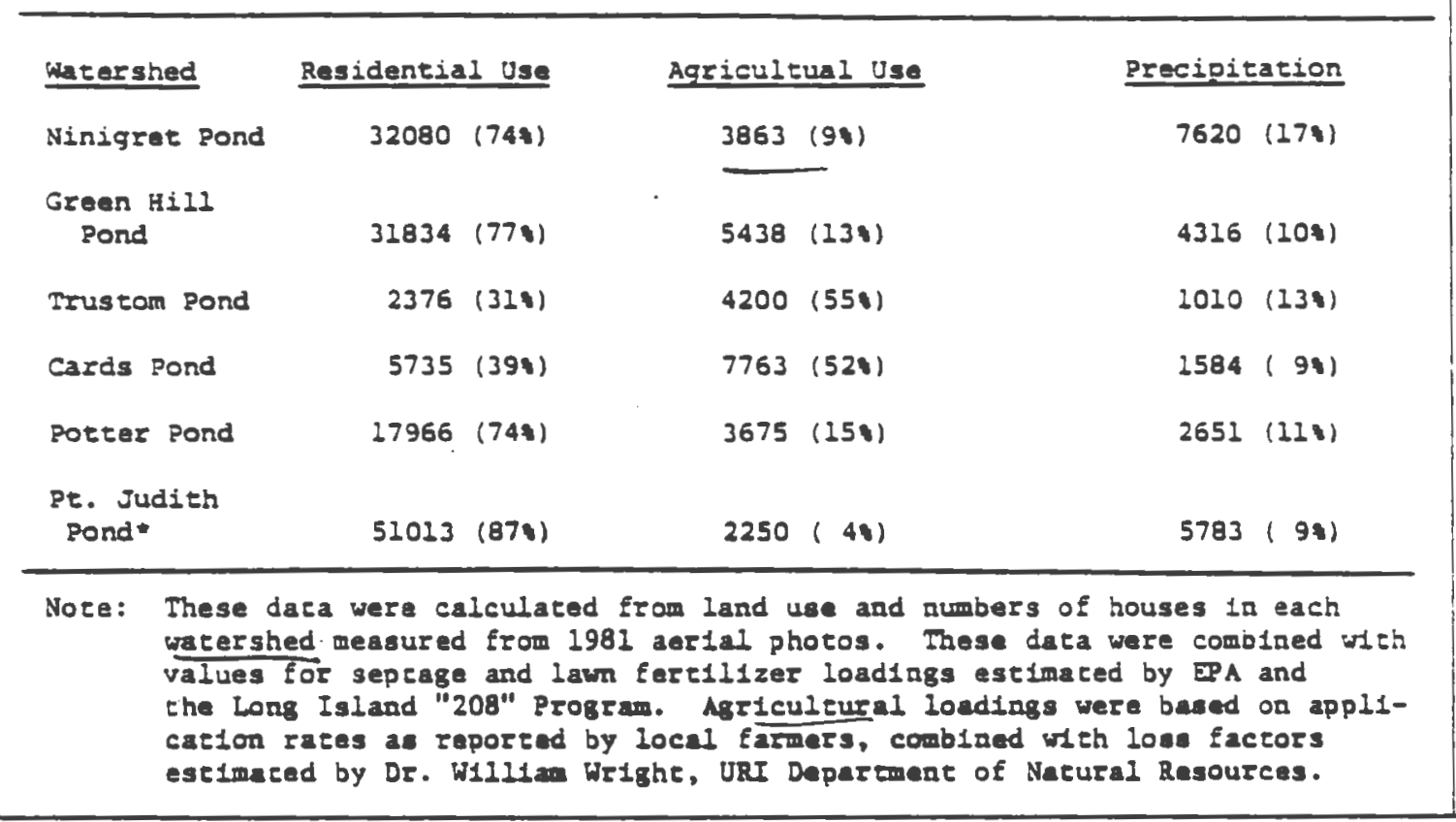

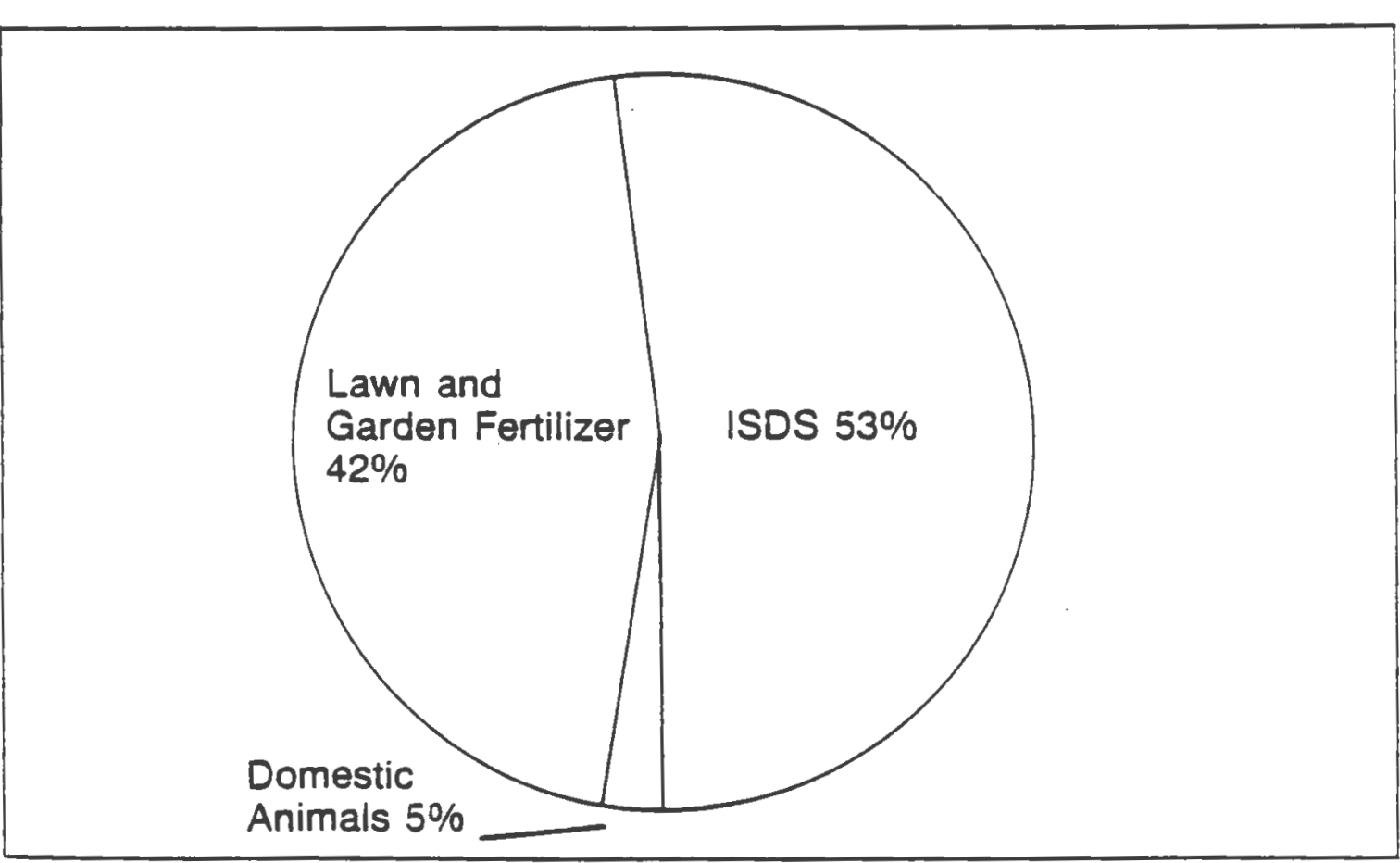

F1gure 3-5. Estimated sources of nitrate nitrogen to groundwater from residential development. Based on loadings reported in the Long Island 208 Plan (1978), this figure shows the nitrate input from an average household of 3 people with 15,050 square feet of lawn and garden. 


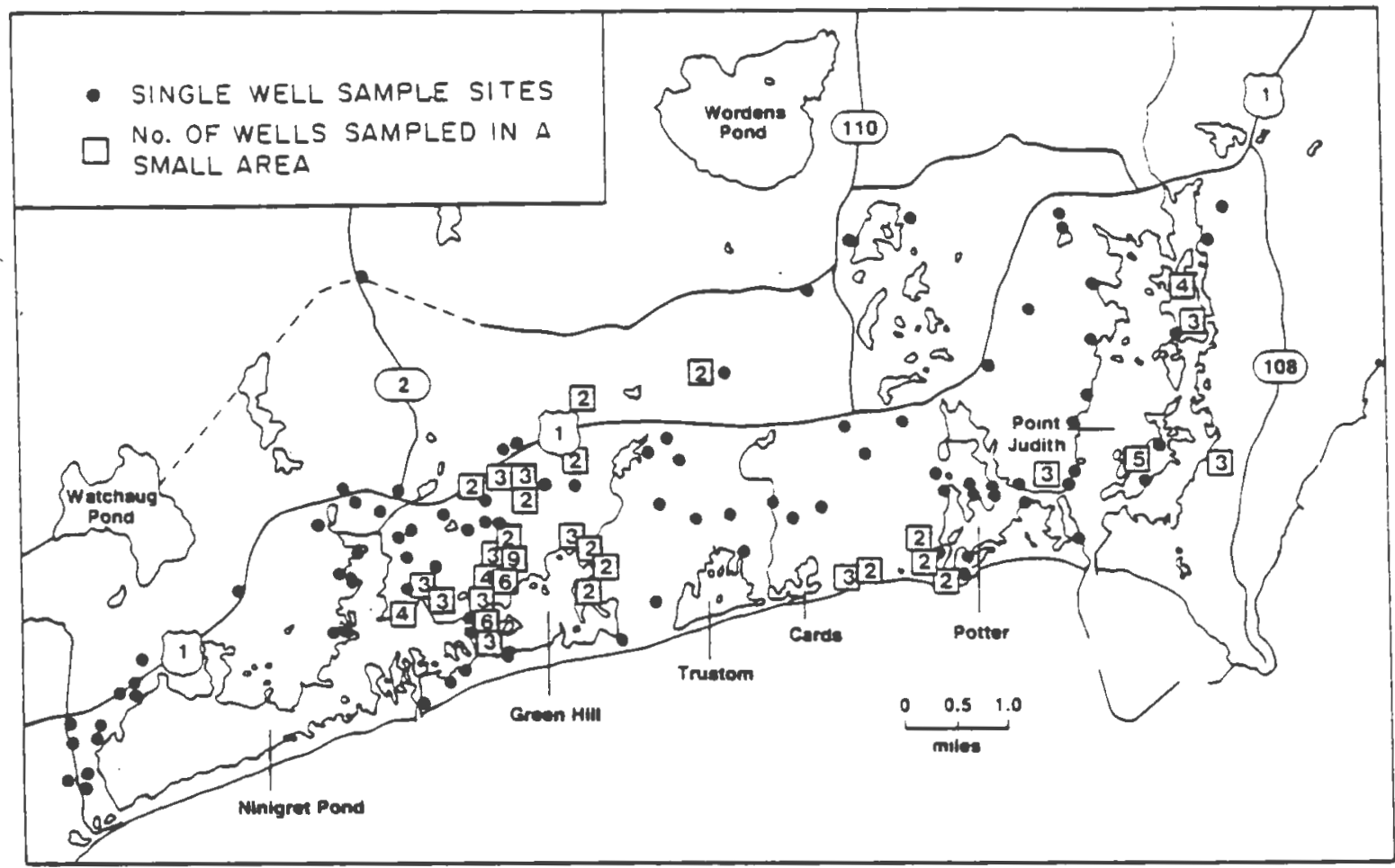

Figure 3-6. Dtstribution of proundwater sampling wells in the salt pond region. Numbers in boxes indicate the number of wells sampled in a small area. N1xon and Nowlckl, 1982.

5. The aitrogen loading to the salt ponds calculated from values provided by the sclentific literature for ISDS, residential fertllizers and other sources, and a detalled analysis of land use $1 \mathrm{n} 1980$ ylelds estimated groundwater aitrate concentrations which are $1 \mathrm{n}$ good agreement with fleld measurements of nitrate levels in 200 wells sampled seasonally throughout the region (FIgure 3-6).2

6. If there is no further residential development in the salt pond region and no steps are taken to address present problems, we may expect further declines $1 \mathrm{n}$ water quality. As ISDS fallures become more frequent, collform concentrations in the salt ponds are likely to cause the Incidence of polluted wells to 1ncrease. The slow rate at which groundwater moves toward the ponds suggests that the impact of much recent development in the watersheds is not yet being expressed as increased annual loadings of nitrate to the ponds. The extent of eutrophication is, therefore, also likely to become more severe even if no additional houses are built in the salt pond region.

310.4 Future Trends

A. Additional Development in the Region

1. Further development throughout the region is inevitable. Estimates for saturation development based on current zoning, and 
accounting for the number of grandfathered substandard lots and such constraints on development as wetlands and poorly draining solls, are shown in Table 3-4. These estimates are theoretically achievable and are a worst case under current zoning. They suggest that the number of residential units in the region could triple and that the human population could increase seven to ninefold.11

2. A seven to ninefold increase in the resident population is expected to increase nutrlent loadings (Table 3-5) to the ponds and trigger more widespread eutrophic conditions. In densely developed areas the levels of nitrate in drinking water are already high and are projected to reach concentrations which would make 1 t necessary to bulld public water systems. Further development anywhere in the region poses problems of Increased nutrient loadlngs to the ponds and major issues concerning the region's capability to provide potable water and and absorb domestic wastes. Some areas are more susceptible to new development than others. Of major concern are areas of potential public water supply and as yet undeveloped tracts adjacent to poorly flushed portions of the salt ponds that are particularly susceptible to bacterial contamination and eutrophication (see Figures $3-7,3-8,3-9$ ).

3. The Rhode Island 208 Program recommends a baseline mialmum lot size of two acres in Charlestown and South $\mathrm{KIngstown}$ where wells and sewage disposal are on-site. 32 This base density for selfsustalning environments has, however, already been exceeded in many areas close to the ponds where houses are crowded together on $1 / 8$ to $1 / 4$ acre lots. In these areas nitrate concentrations in the underlying groundwater are high, many wells are polluted with bacteria, and adjacent pond waters frequently show the greatest evidence of pollution. 20 Every effort must be made to reduce the sources of pollution in these areas. Aquifers that are capable of providing a potable water supply to these communitles must be protected. Lands upflow of densely developed areas should be developed at as low a density as possible so as to minimize the nitrate concentration in groundwater before 1 t reaches those highly stressed areas. For these reasons the URI Coastal Resources Center has urged Charlestown and South Kingstown to amend their zoning plans to provide for as large lots as possible in areas of potential water supply and upflow of densely developed lands.33,34

B. MaIntenance and Improvement of ISDS Systems

1. The IIfe of an ISDS and the effectiveness with which the system treats sewage may both be substantially 1mproved by regular pumpling of the septic tank. The Rhode Island 208 Program recommends pumping every three years. 32

2. A major problem in the salt pond region is that many homeowners are unaware of how their wastes are being treated and do not realize that an ISDS should be regularly malntalned. South Kingstown offers rebates to encourage pumping, but this has not 
TABLE 3-4. The Potential for Increases in Residential Units in the Salt Pond Region at Saturation Development

\begin{tabular}{|lccc|}
\hline Watershed & $\begin{array}{l}\text { Houses } \\
\text { in } 1980\end{array}$ & $\begin{array}{c}\text { Houses Projected } \\
\text { at Saturation }\end{array}$ & $\begin{array}{c}\text { Increase } \\
\text { Factor }\end{array}$ \\
\hline Ninigret & 1,228 & 4.816 & 3.9 \\
Green H111 & 1,223 & 3,850 & 3.1 \\
Trustom & 80 & 246 & 3.1 \\
Cards & 202 & 1,095 & 5.4 \\
Potter & 755 & 1,902 & 2.5 \\
Pt. Judith & 2,028 & $\underline{5,050}$ & 2.5 \\
Total Region & 5,516 & 16,959 & 3.1 \\
\hline
\end{tabular}

Note: Estimates of saturation development are based on a tabulation of lots of record (1983) and a determination of potential building sites $1 \mathrm{n}$ the salt pond region.

Tabulation of Existing Lots of Record: Tax maps and assessment records were used (vacant lots in existing "grandfathered" subdivislons). Zonfing maps (1983) were consulted to determine the zoning category of vacant lots in developed areas.

Determination of Potential Bullding Sites: Lots In existing platted subdivisions were counted in each town. Lots of less than the applicable zoned lot size were counted as bulldable lots in cases where lots were in separate and non-contiguous ownership. Contiguously owned lots were comblned to conform as much as possible with present zoning categorles. In developed areas lots exceeding minimum lot size were reviewed to see whether they could yield additional bullding sites. In undeveloped areas the acreage in large lots were recorded and divided by the applicable minlmum zoning lot slze, and adjusted for road requirements. Lots which were publicly owned and used for conservation purposes, such as the Federal w1ldlife Refuges, state salt marshes, beach areas, and wildlife management areas, were not included in the calculation. Lots which occupied the sites of wetlands as presented in the National Wetlands Inventory, 1980, in excess of 3 acres were not included in the calculation since they are protected by state wetlands protection laws and ISDS regulations. 
TABIE 3-5. Projected N1trogen Loading to the Salt Pond Watersheds at Saturation Development. Loading Units are in Pounds Per Year and Nitrate Concentrations in Groundwater are in Parts Per Milition.

\begin{tabular}{|c|c|c|c|c|c|c|c|}
\hline \multicolumn{2}{|c|}{ Source } & $\begin{array}{l}\text { Ninigret } \\
\text { Pond }\end{array}$ & $\begin{array}{l}\text { Green } \\
\text { Hill1 } \\
\text { Pond }\end{array}$ & $\begin{array}{c}\text { Trustom } \\
\text { Pond }\end{array}$ & $\begin{array}{r}\text { Cards } \\
\text { Pond }\end{array}$ & $\begin{array}{c}\text { Potters } \\
\text { Pond }\end{array}$ & $\begin{array}{c}\text { Pt. Judith } \\
\text { Pond }\end{array}$ \\
\hline \multicolumn{2}{|c|}{$\begin{array}{l}\text { Residential } \\
\text { Sept1c } \\
\text { Lawns }\end{array}$} & $\begin{array}{r}119,975 \\
72,240 \\
41,811 \\
5,924 \\
119,975\end{array}$ & $\begin{array}{r}94,313 \\
57,750 \\
31,827 \\
4,736 \\
94,313\end{array}$ & $\begin{array}{r}5,216 \\
3,690 \\
1,223 \\
303 \\
5,216\end{array}$ & $\begin{array}{r}30,348 \\
16,425 \\
12,576 \\
1,347 \\
30,348\end{array}$ & $\begin{array}{r}50,753 \\
28,530 \\
19,884 \\
2,339 \\
50,753\end{array}$ & $\begin{array}{r}153,757 \\
101,775 \\
43,636 \\
8,346 \\
153,758\end{array}$ \\
\hline \multicolumn{2}{|c|}{$\begin{array}{l}\text { Agr lcultural } \\
\text { fert } 111 \text { zer }\end{array}$} & 0 & 0 & 0 & 0 & 0 & 0 \\
\hline \multirow{2}{*}{\multicolumn{2}{|c|}{$\begin{array}{l}\text { Precipitation } \\
\text { Total Loading }\end{array}$}} & 7,620 & 4,316 & 1,010 & 1,584 & 2,651 & 5,783 \\
\hline & & 127,595 & 98,629 & 6,226 & 31,932 & 53,404 & 159,540 \\
\hline \multicolumn{2}{|c|}{$\begin{array}{l}\text { Estimated } \\
\text { Groundwater } \\
\text { Concentration } \\
\text { At Saturation } \\
\text { Development }\end{array}$} & 5.1 & 6.9 & 1.9 & 6.1 & 6.1 & 7.4 \\
\hline \multicolumn{8}{|c|}{$\begin{array}{l}\text { Note: The estimated concentrations of nitrate in groundwater at } \\
\text { saturation development are average values in each watershed. } \\
\text { Nitrate concentrations were already at the } 1-5 \text { ppm range by } \\
\text { I } 981 \text { in many densely developed areas. Here additional } \\
\text { Ioadings are expected to result in nitrate concentrations } \\
\text { in the } 10 \mathrm{ppm} \text { range. }\end{array}$} \\
\hline
\end{tabular}


brought an appreciable increase in this form of maintenance. Another problem is that people are reluctant to report on a neighbor whose system is failing. At workshops on this plan, residents of the older, densely developed communities around the ponds have acknowledged that ISDS fallures are commou during the summer season and that even direct discharges to the ponds exist, but they are very reluctant to report these problems to the authorities.

3. The DEM Division of Land Resources issues permits for ISDS to insure that minimum standards are upheld in the siting, design and construction of such systems. According to state regulations, an ISDS must meet siting standards that include a minimum depth to groundwater, a minimum and maximum soll percolation rate, and setbacks from lot 1 ines, drinking water wells, wetlands and coastal features. 35 These standards relate primarily to public health considerations. The CRMC regulates ISDS for their potential impacts on the coastal environment.

4. Alternative technologies for small-scale waste treatment are being used successfully by communities throughout the country and by at least one housing complex in the salt pond region. 36 When these systems are properly maintained, they provide important alternatives for wastewater treatment problems in localized areas. A variety of types of treatment are avallable, ranging from package sewage treatment systems for clusters of development to facilities designed for individual dwellings. The DEM does not encourage such package systems, since experience in both Rhode Island and Massachusetts demonstrates that many of those systems fall or are prone to problems. The poor record is attributed to lack of maintenance aud poor operating procedures.

5. In response to the need for regular maintenance and, where necessary, repair and replacement of ISDS in the salt pond region, the DEM, the CRMC and the local town governments are worklng together on: (1) delegation of authority to local goverments for ISDS maintenance programs and identification of failed or substandard systems, (2) faster response by state agencles to reported fallures, (3) the establishment of standards for rehabilitation of substandard systems, (4) options for municlpally owned package sewage treatment plants, and (5) public education programs and identification of sources of funding for ISDS repair.

\section{Public Sewer Systems}

1. A cormon response to the pollution of surface water bodies and groundwater by suburban development is to build sewers. Sewers, however, are too expensive to be a realistic solution for much of the region, and they ralse another set of issues. 
Once an area is sewered, many of the constraints that presently limit development disappear (soils that meet percolation standards, minimum distances between ISDS and wells or roads). The experience of many communities natiomide demonstrates that sewer systems encourage high density development and increase runoff contamination of adjacent water bodies 25,32 Increased runoff may be expected to carry sediments, nutrients, petroleum, metals and other contamiluants to the ponds. Sewers are an appropriate solution for urban areas where other alternatives are no longer available, but not for areas where less dense development is a feasible and desirable alternative.

\section{Public Water Systems}

1. A common response to widespread groundwater pollution is to construct public water systems. This option, however, brings the problems that sewer construction entails; it encourages development, and is expensive to bulld and maintaln. Increasing the level of development increases the likelihood of polluting the region's groundwater which supplies both public water systems and private wells. If contaminated, groundwater aquifers in the region would require hundreds of years to recharge and cleanse pollutants. There are no significant alternative sources of drinking water within the salt pond reglon. When groundwater supplies on Long Island became contaminated with high nitrate levels from dense suburban development in the 1970s, municipalities drilled through clay layers to a deeper uncontaminated aquifer. 9 There is no such option in the salt pond region, where the glacial aquifer extends down to bedrock.

2. Providing freshwater systems for expanding residential development has the additional problem of altering the flow of fresh water into individual salt ponds. A public water supply system that draws from the watershed of one pond and exports it to. the watershed of another alters the flow of freshwater to the two ponds. This can have potentially profound impacts on their ecology. The wells that supply the existing South Shore Water System presently withdraw 6 percent of the freshwater flow to Green H1ll Pond. 20 If all the houses that can legally request tie-ins to the existing water mains do so, the anmul freshwater flow to Green Hill will be reduced by 17 percent, and the freshwater inflow increased to other ponds to the east. 20

\section{E. Buffer Zones}

1. Undisturbed zones along the perimeter of salt ponds, their tributaries and associated wetlands play an important role in preserving the qualities of the coastal environment. These benefits are summarized in Section 150 of the R.I. Coastal Resources Management Program and include erosion control, checking the flow of pollutants, protection of flora and Eauna, and the preservation and enhancement of scenic qualities. Wide buffer zones will 
be particularly important on lands designated in Figures 3-7, 3-8 and 3-9 as Lands of Critical Concern. These as yet undeveloped or sparsely developed tracts abut poorly flushed portions of the salt ponds, which are therefore particularly susceptible to pollution. Their undisturbed shorelines are valuable natural habitats with high scenic values. Wide buffer zones are also needed in these areas to minimize flood damage, and have the additional benefit of protecting the numerous archeological sites that are clustered along the pond's shorelines.

2. Many states require or recommend buffer zones of widths ranging from 150 to 1,000 feet to protect water bodies $E$ rom pollution. Buffers 100 to 300 feet wide are recommended to protect surface water bodies from sedimentation and 300 to i,000 feet are recommended for 50 percent to 90 percent nutrient removal from runoff waters. $40,41,42,43,44$ The Rhode Is land 208 Program recommends a minimum buffer width of 100 feet along ail ponds and streams, and a minimum of 300 to 400 from critical areas such as public water supplies. According to surveys conducted by the R.I. Historic Preservation Commision, around Potter Pond two-thirds of the important archeological sites are within 650 feet of the shoreline and 80 percent of the artifacts within 300 feet of the shoreline.45

\subsection{Other Contaminants}

A. A great number of substances, if present at sufficient concentrations, can be toxic to people or salt pond organisms. In the salt pond region, where residential and recreational uses dominate, candidate pollutants in driaking water include the chemicals from septic system "conditloners," petroleum hydrocarbons from leaking fuel o1l and gasoline storage tanks, leachate from sanitary landfills, herbicides and pesticides. 9

B. There is growing recognition nationally that underground storage of petroleum is a serious threat to groundwater quality. 37 As buried gasoline or heating oil tanks age and corrode, they develop leaks that are difficult to detect. The average life span of underground petroleum storage tanks is estimated to be 20 years. There have already been several cases in Rhode Is land where petroleum leaking from a storage tank has contaminated drinking water aquifers.37 The Department of Environmental Management is taking steps to regulate commercial underground petroleum storage tanks in order to protect groundwater resources statewide. 38

C. In the ponds, petroleum hydrocarbons, copper from antifouling palnt, creosote from pilings, and a variety of substances carried by surface runoff can degrade water quality. These pollutants have not been assessed in the salt pond region, but it is evident from studies done elsewhere in the nation that they are potentially Important. 25, 32 


\section{MANAGEMENT REGULATIONS AND INITIATIVES}

320.1 Land Use Classiflcation for Watershed Protection See Figures 3-7, 3-8, and 3-9.

A. Self-sustalning Lands

1. Definition. These lands are undeveloped or developed at a density of not more than 1 residential unit per 2 acres. In these areas, the nutrients released to groundwater by ISDS, fertilizers and other sources assoclated with residential activities may be expected to be sufficlently diluted to matntain potable groundwater.

2. Management Policles and Regulations

(a) In order to be in conformance with this plan, subdivisions shall not exceed a density of 1 residential unit per 2 acres.

(b) Cluster development is recommended as a means to preserve open space, aesthetic qualities, and agricultural lands, reduce the costs of development, and minimize the environmental impacts of development. For CRMC purposes, the number of units in a cluster shall be calculated on the basis of developable land within the subdivision in accordance with all DEM regulations and local ordinances, and exclude wetlands, soils that do not meet ISDS standards, and lands included within setbacks from lakes, stream beds and wetlands.

(c) Public water service Is considered a low priorlty. Where a public water supply is deemed necessary, the source wells and the distribution Ilnes shall remain within a single watershed (as defined in Figure 3-1) and not divert groundwater from one salt pond watershed to another.

(d) Sewers are prohtbited.

(e) Where lands in this category abut salt ponds or their tributaries, a wide buffer zone shall be provided in accordance with Section 150 of the Coastal Resources Management Program, as amended.

\section{B. Lands of Critical Concern}

1. Definition. These lands are undeveloped or developed at a density of not more than 1 residential unit per 2 acres and (a) abut sensitive salt pond areas that are particularly susceptible to eutrophication and bacterial contamination and/or (b) overlfe aquifer recharge areas for existing or potential water supply wells.

2. Management Policies and Regulations

(a) Policies and regulations (a) through (d) above apply. 


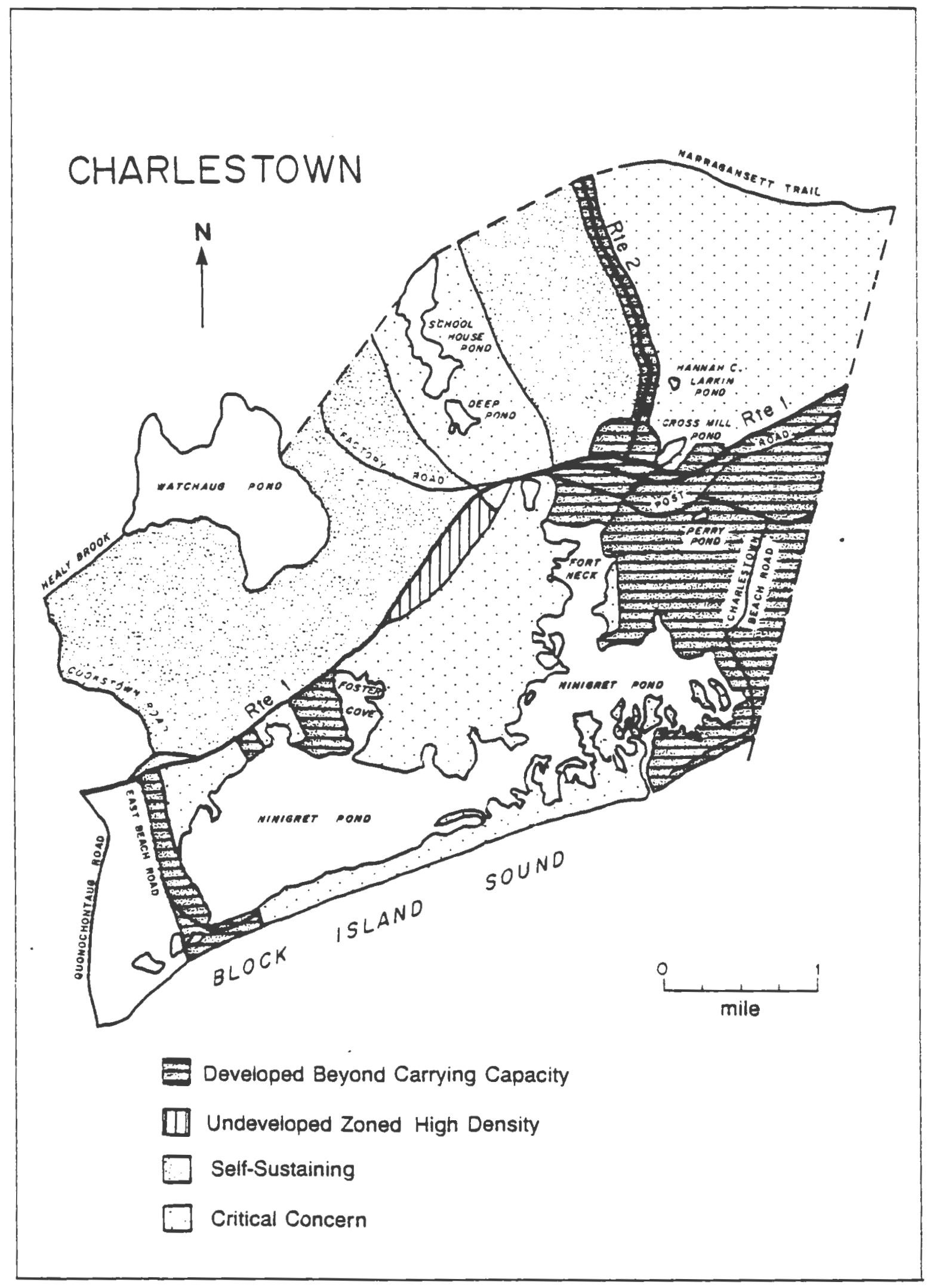

Figure 3-7. Land use classification for water quality protection in the town of Charlestown. 


\section{SOUTH KINGSTOWN}

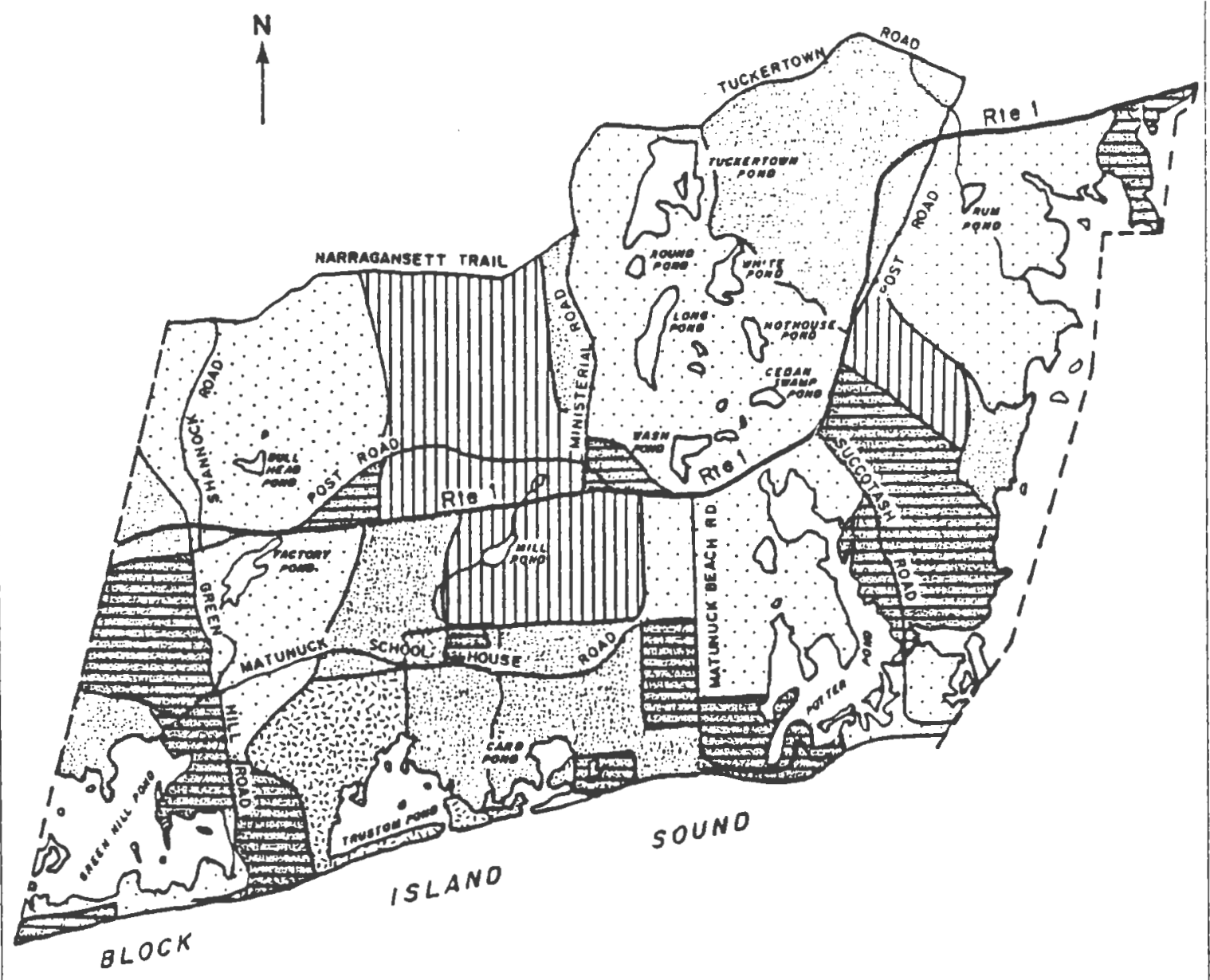

Developed Beyond Carrying Capacity

DI Undeveloped Zoned High Density

Self-Sustaining

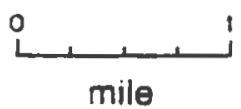

$\square$ Critical Concern

P.: Federal Land

Figure 3-8. Land use classification for water quality protection in the town of South Kingstown. 


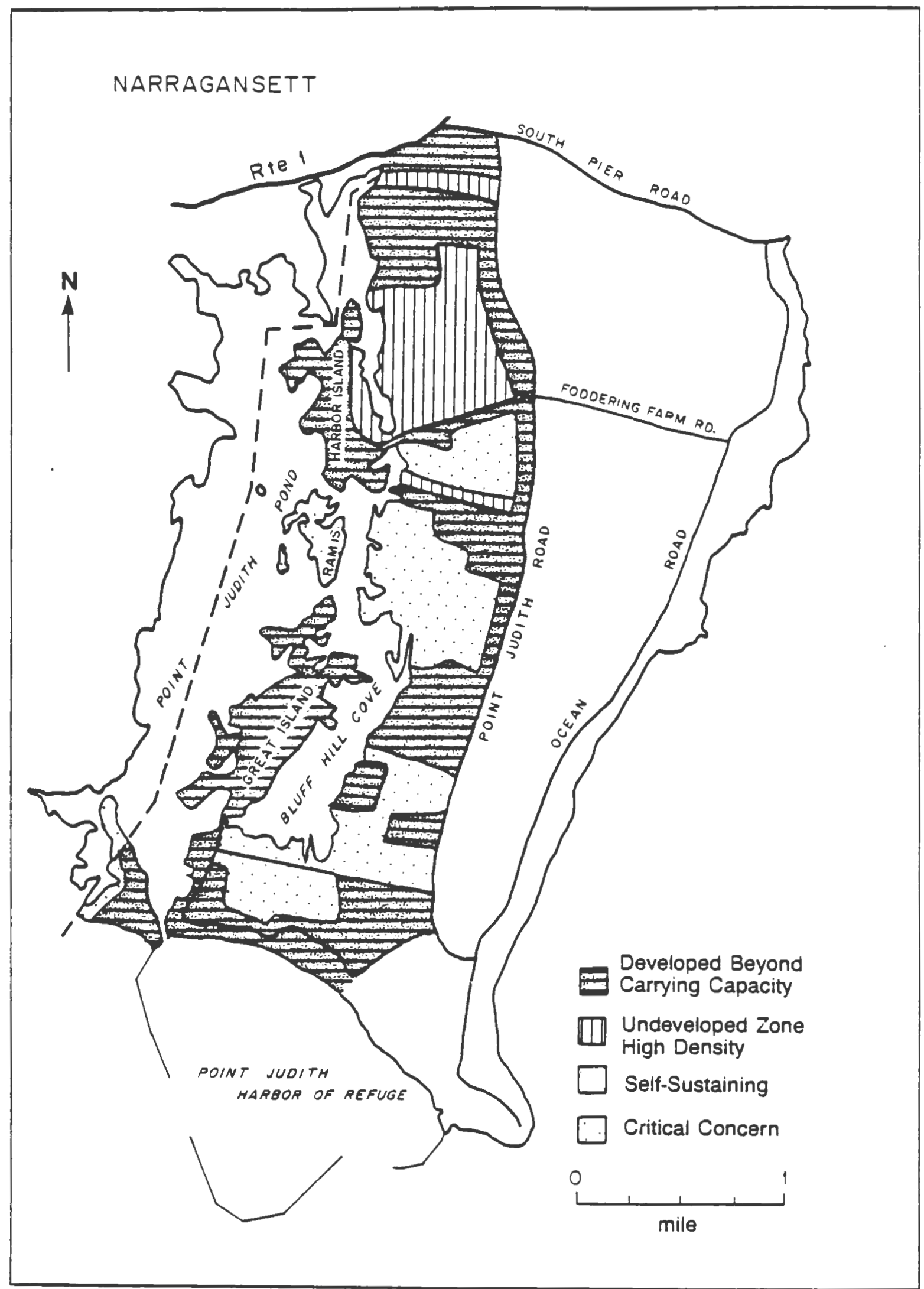

F1gure 3-9. Land use classification for water quality protection in the town of Narragansett. 
(e) These areas are priorities for additional measures to minimize pollution loadings from development through acquisition, conservation easements, tax relief and aquifer protection ordinances.

(f) A 200-foot-wide natural buffer zone shall be provided in those areas that abut the salt ponds, their tributaries and contiguous wetlands.

(1) Activities permitted within the buffer strip may include the cutting and malutenance of foot paths and rights of way, selective thinning of trees, placement of duck blinds, and, in Type 2 waters, one dock per lot of record as of January 1983.

(2) Activities prohibited within the buffer strip include the construction of buildings, sewage disposal systems or leachbeds, surfaced roadways, culverts, bulkheads, riprap and lawns. Fertilizers shall not be applied within buffer zones except where necessary to establish vegetation in areas that are eroding or need to be restored.

(g) Denttrification units shall be required in accordance with Section 320.28 .

\section{Lands Already Developed Beyond Carrying Capacity}

1. Definition. These lands are developed at densities above carrying capacity, frequently at one residential or commercial unt per $1 / 8$ to $1 / 2$ acre. Such intense development is the major source of contamination to groundwater and the salt ponds. High mutrient loadings and contaminated runoff waters are resulting in a high incidence of polluted wells and increasing evidence of eutrophic conditions and bacterial contamination in adjoining salt pond waters. Most of the individual sewage disposal systems in these areas predate state-enforced siting and design standards and are approaching their expected life span.

2. Management Policies and Regulations

(a) Regular malntenance and, when necessary, the upgrading of ISDS are of the highest priority in unsewered densely developed areas (see Section 320.2C). (b) Densely developed lands on Great Island and Harbor Island in Narragansett and at the northern end of Point Judith Pond in South KIngstown are In close proximity to existing sewer lines; in these areas extension of sewer service is a priority.

(c) Public water service is a high priority. Where practical, the supply wells and service areas for public water supplies shall be kept within individual watersheds; the export of groundwater from one watershed to another shall be minimized.

(d) Buffer zones along the perimeter of salt ponds and tributarles shall be negotiated by the CRMC in accordance 
with Section 150 of the Coastal Resources Management Program, as amended.

D. Undeveloped Lands Zoned for High Density Development

1. Definition. These as yet undeveloped lands are zoned or subdivided for residential or commercial development at a density of 1 acre or less. Such dense development is expected to become a source of contamination to the groundwater and the salt ponds.

2. Management Policies and Regulations

(a) Regular maintenance and, where necessary, the upgrading of ISDS are high priorities in unsewered areas (see Section $320.2 \mathrm{C}$ ).

(b) Sewers shall not be permitted by the CRMC in lands of this category along the eastern shore of Point Judith Pond.

(c) Wide buffer zones abutting salt ponds, their tributaries and contiguous wetlands shall be negotiated by the CRMC in accordance with Section 150 of the Coastal Resources Management Program.

(d) These are priority areas for amendments to zoning plans to provide for a mialmum 2 acre lot size, conservation easements, and cluster development.

(e) Denitrification units shall be required in accordance with Section 320.2B.

\subsection{Controls to Minimize Sources of Pollution}

\section{A. Point Sources of Runoff}

1. Defintion. A point source of runoff is a direct discharge of raluwater, melted snow or Irrigation water to a salt pond or tributary stream through a pipe or similar conduit.

2. Management Policies and Regulations

(a) New or enlarged polnt discharges of runoff to the salt ponds and their tributaries are prohibited.

(b) Dralnage swales or holding basins shall be designed to permit sediments to precipitate and runoff water to be cleansed as it moves through the soll and then to an adjacent waterbody. Drainage swales and basins shall be regularly malntalned and cleaned of sediment and obstructions.

(c) Prlority sites for construction of dralnage swales to treat existing major discharges of highway runoff are identified on Figure 3-10 and shall be required by the CRMC when these roadways are upgraded. 


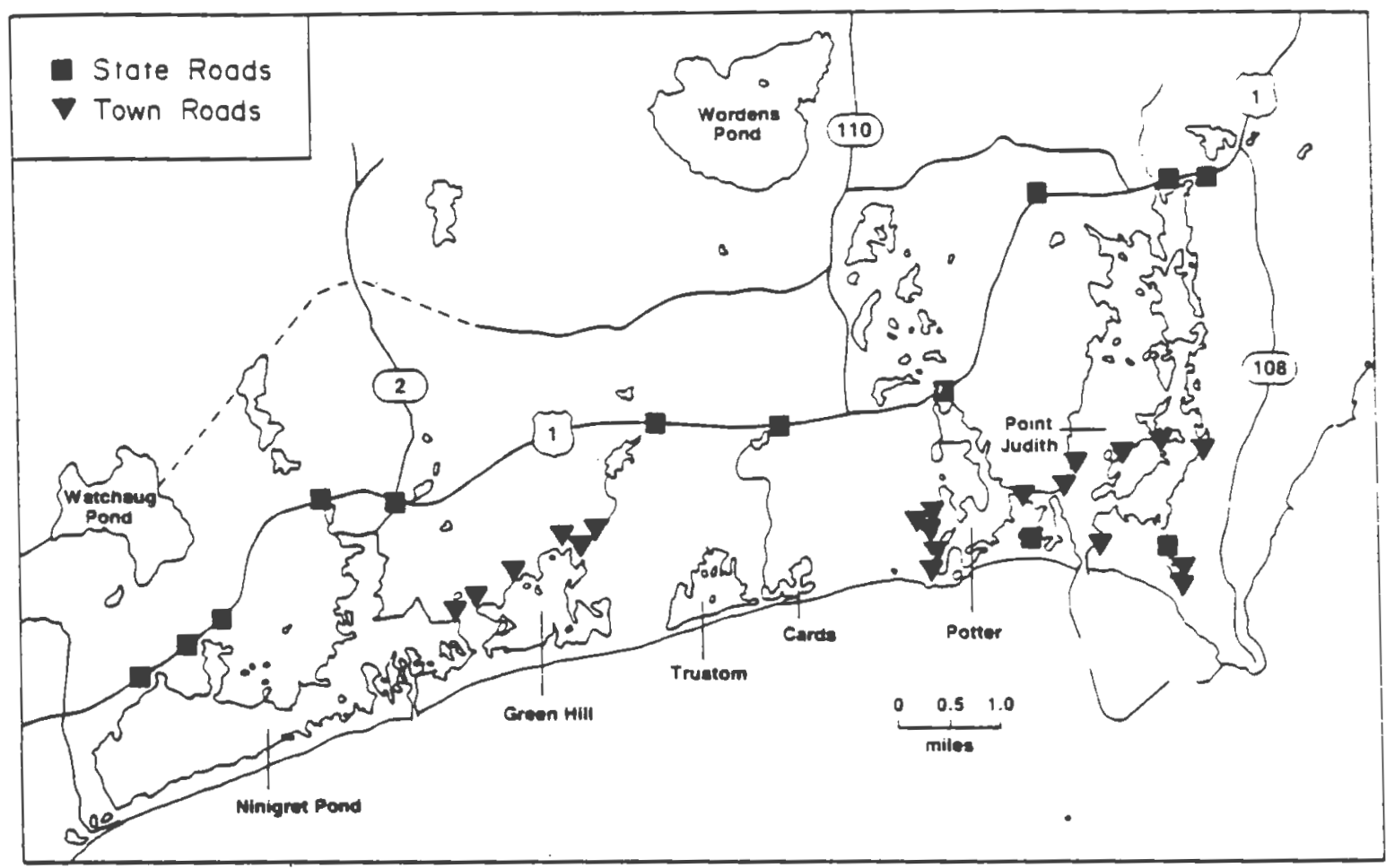

Figure 3-10. Direct discharges of stormwater runoff from roads and highways in the salt pond region.

\section{B. Denttrification of Domestic Sewage}

1. Definition. Denterification is that process by which the nttrogen in sewage is converted to nttrogen gas and released to the atmosphere.

2. Management Policles and Regulations

(a) The CRMC shall evaluate the effectiveness and maintenance requirements of dentrification systems sultable for use with ISDS by September 1985. If such systems are found to sigrificantly reduce nutrient loadings to groundwater they shall at a minimum be required for all new and upgraded ISDS in Lands of Critical Concern (Section 320.1B), Lands Already Developed Above Carry1ng Capac1ty (Sec. 320.1C) and Undeveloped Lands Zoned for High Density (Sect1on 320.1D).

\section{ISDS Upgrading and Maintenance}

1. ISDS Upgrading. A large proportion of the ISDS in the salt pond region predate state construction standards, and many are approaching the expected 11fe span of an ISDS. Densely developed 
older communities are the priority sites for upgrading and replacing existing ISDS. With technical assistance from the DEM Division of Land Resources (ISDS office), the municipalities are encouraged to target problem areas for intensive educational programs and phased replacement of failed or substandard ISDS. Tax credits could be provided to help offset the expense to homeowners, and federal funds may be available to provide low interest loans or grants for such intlatives.

2. ISDS Maintenance Pumpling Program. The muntclpalities are encouraged to support educational programs such as those Initiated by the Action Commttee (Section 320.3A) and to promote regular malintenance pumping of ISDS systems within the salt pond region. Economlc lncentives such as municlpal tax rebates or reduced community rates from private pumpers are lmportant lincentives for the success of such a program. Educational material should be distributed to Inform residents of the 1mportance of maintaining thelr ISDS systems, how such maintenance should be carried out, and the role of effective on-site sewage treatment In malntalning potable groundwater and reducing the risks of bacterlal contanination and eutrophication in the salt ponds. The program may 1nclude pamphlets, workshops, site visits by DEM officials and media spots.

\section{Control of Pollution from Petroleum Storage Tanks}

1. Definition. In-ground petroleum storage tanks include tanks for gasoline, heating oll, diesel fuel or other petroleum compounds for comerclal establishments and for household use.

2. Management Policles and Regulations

(a) Burlal of domestic fuel ofl storage tanks is prohibited in the salt pond reglon.

(b) All persons proposing to 1nstall a burled storage tank for gasoline, fuel oil or other petroleum product, or any other substance defined as hazardous by DEM shall apply for a CRMC permit. Applicants shall be required to demonstrate an adequate construction design and means for montorling for leakage, and shall replace all leaklng tanks according to standards set forth in DEM regulations for underground storage facilities for petroleum products. 38

E. Pump-Out Facilities at Marinas

The Coastal Resources Management Counc1l shall seek to make provisions for the installation of sewage pump-out facilities for recreatlonal craft and appropriate pretreatment at the head and mouth of Point Judith Pond. Those facllitles shall be reqularly ma1nrenance-pumped or connected to public sewer 11 nes. 
F. 011 Spil1 Contingency

011 spills shall be treated 1 a accordance with the Rhode Island 0 il Spill Contingency Guide. 39

1. Point Judith and Potter Ponds. A spill in lower Point Judith Pond should if possible be contained within the port area. However, there are both substantial fishing boat traffic and strong currents in the port which will complicate oil cleanup operations. In many cases the best practical containment strategy if ofl enters the lower pond w1ll be to divert oil to the shore on the Jerusalem side of the channel. Every effort shall be made to keep the ofl from entering Potter Pond through Goosebery Hole or East Pond under the Great Is land Bridge.

2. Ninigret and Green Hill Ponds. Every effort shall be made to deflect an offshore oll spill away from the breachway and the ponds. and toward the ocean beaches. The fast currents in the breachway make tt a difficult place to deploy booms or mops. If ofl cannot be kept out of the breachway, it should be contained along the banks just inside the breachway where the channel widens and currents are slower. A boat launch ramp and access for heavy equipment are avallable from the parking lot on the east side. Sand from the area should be used to block small channels and create impoundments.

3. Trustom and Cards Ponds. Since these ponds are only temporarily breached, there is little danger of oil entering them. If a spill occurs when the breachways are open, every effort should be made to fill them in with sand from the adjacent beach.

\subsection{Public Education Programs and Future Research}

\section{A. Public Education}

The CRMC recognizes that public education is one of the most effective means for decreasing pollution loadings and preventing contamination in the salt pond region.

A priority for the Action Committee shall be to infliate a public education program to set forth what a homeowner and developer can do to minimize pollution in the salt pond region. Such a program would include educational matertals explaining how septic systems work and why they should be routinely malntalned (Section 320.2C); the 1mportance of minimizing use of fertilizers, pesticides and herbicides; the option of seaweed harvesting and lts use as a garden fertllizer, and techniques to minimize runoff.

\section{B. Further Research}

The CRMC recognizes that further research is needed to help protect 
the salt ponds. As funding becomes available, research priorities shall include the following:

- Small-scale communtty sewage treatment systems. Optimal design, malntenance, and siting requirements need to be investigated to evaluate whether these systems may be used to 1 mprove the water quality problems that exist in densely developed areas. Portlons of the south shore drain offshore instead of into the ponds and they should be considered as sites for multi-unit systems using inground discharge to leaching beds to dissipate treated waters.

- Future sources of drinking water. The sites and estimated yields for systems to supply lands developed above their carrying capacity should be identified.

- Elimination of mulsance algae. The possibility of removing unaesthetc algal growth from the salt ponds should be evaluated.

- Runoff control. As the pond region becomes more developed, runoff will become a larger source of contamination to the ponds and their tributarles. Much work is needed to assess means to control and purify this source of pollution.

- Understanding the causes of eutrophication. More research is needed on the dy namics of eutrophication in shallow, saline estuarine systens dominated by macrophytes. Research

- Long-term monitoring of water quality parameters. Monitoring and research projects by the University, state agencles, and ocher lnscleuclons should be encouraged. A data agenctes and the research commut ty should be to mangent and maintained. 